S 451

. C7 A2

1901 


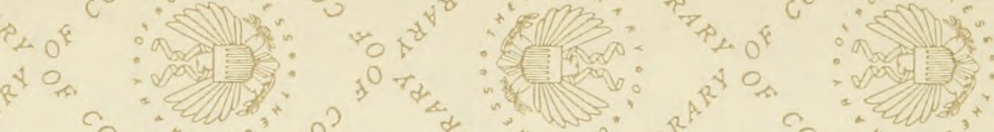

ind $a^{2}: 2^{2}$

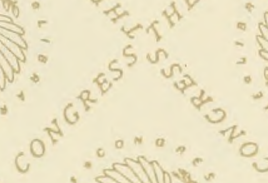

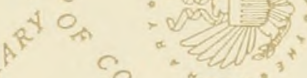

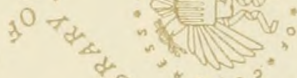

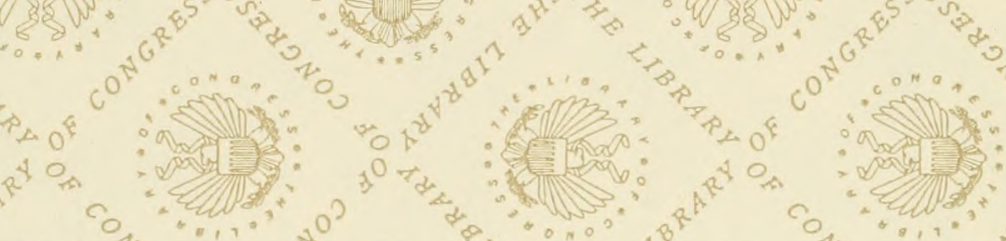

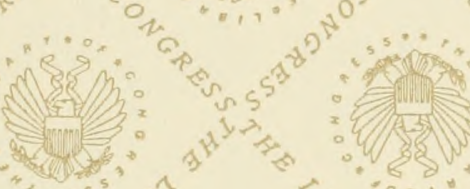

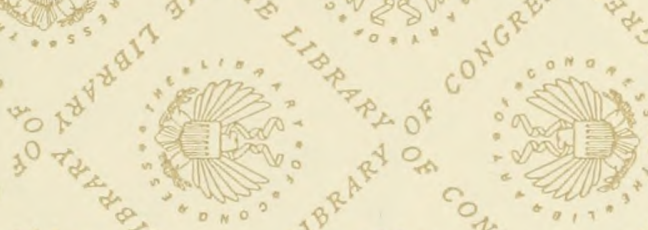

ans

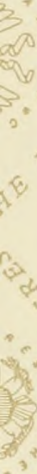

in 30 के $5^{2}$ 


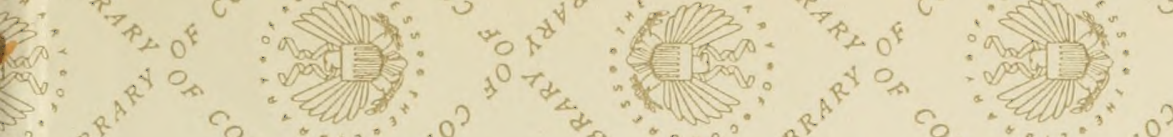

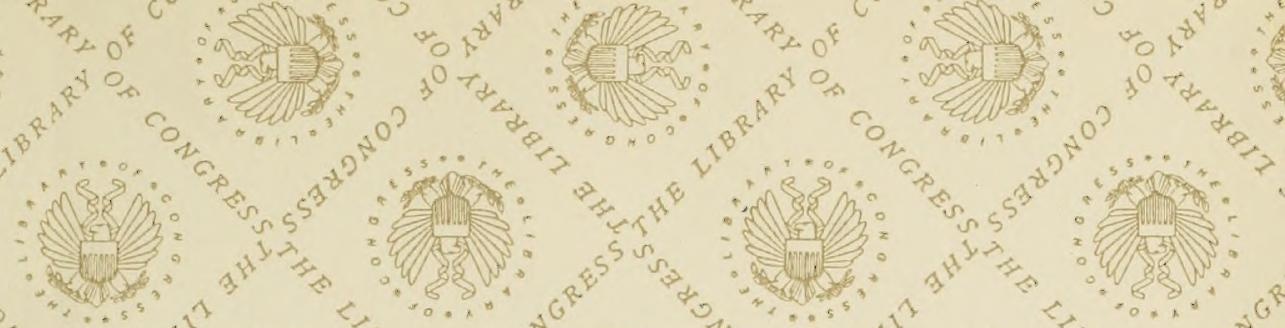

(1)

年

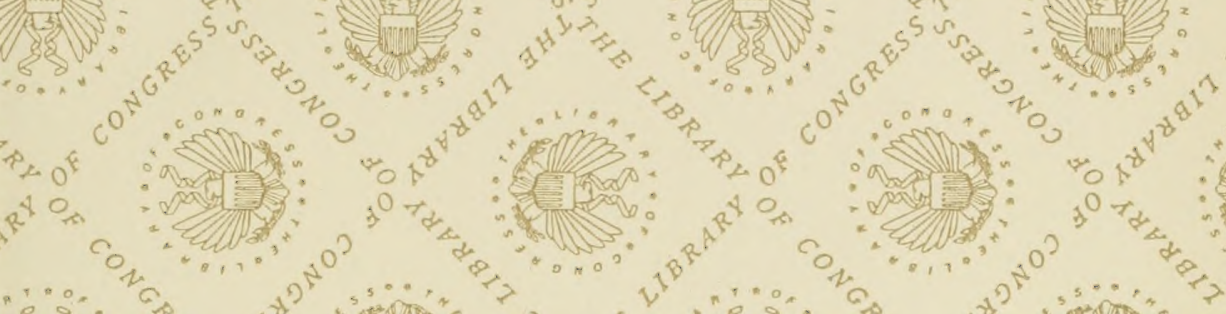

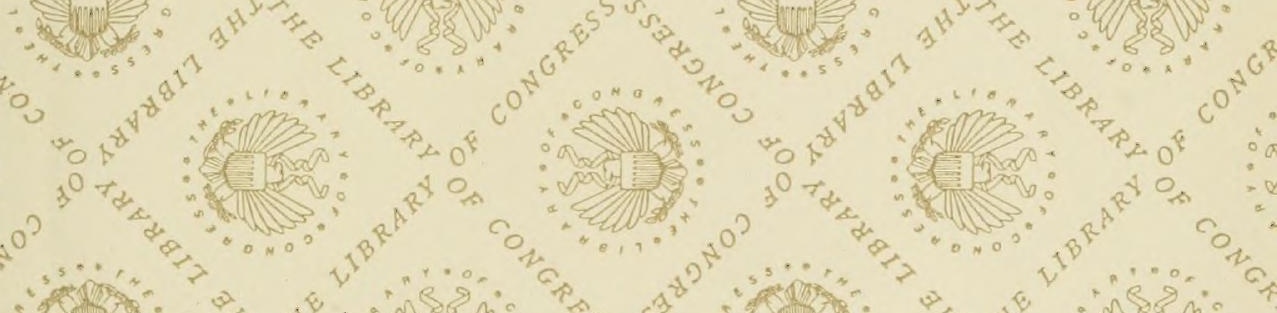

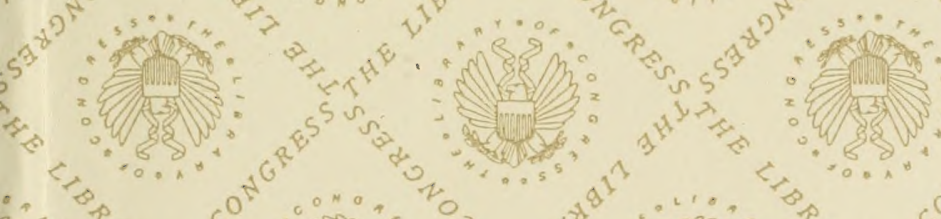

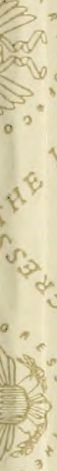

40

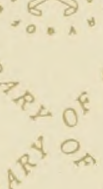

$a^{5^{5}} \sin ^{5}$

(e)

$0^{\circ} \ldots \cdots+\cdots$

$\therefore s^{s^{3}} y^{\gamma^{2}}$

?

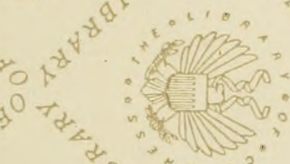

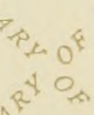

c.......

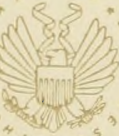

$\therefore$ (a)

$\lambda^{0} \gamma_{\alpha}$

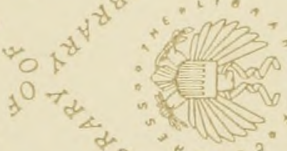

(n) 





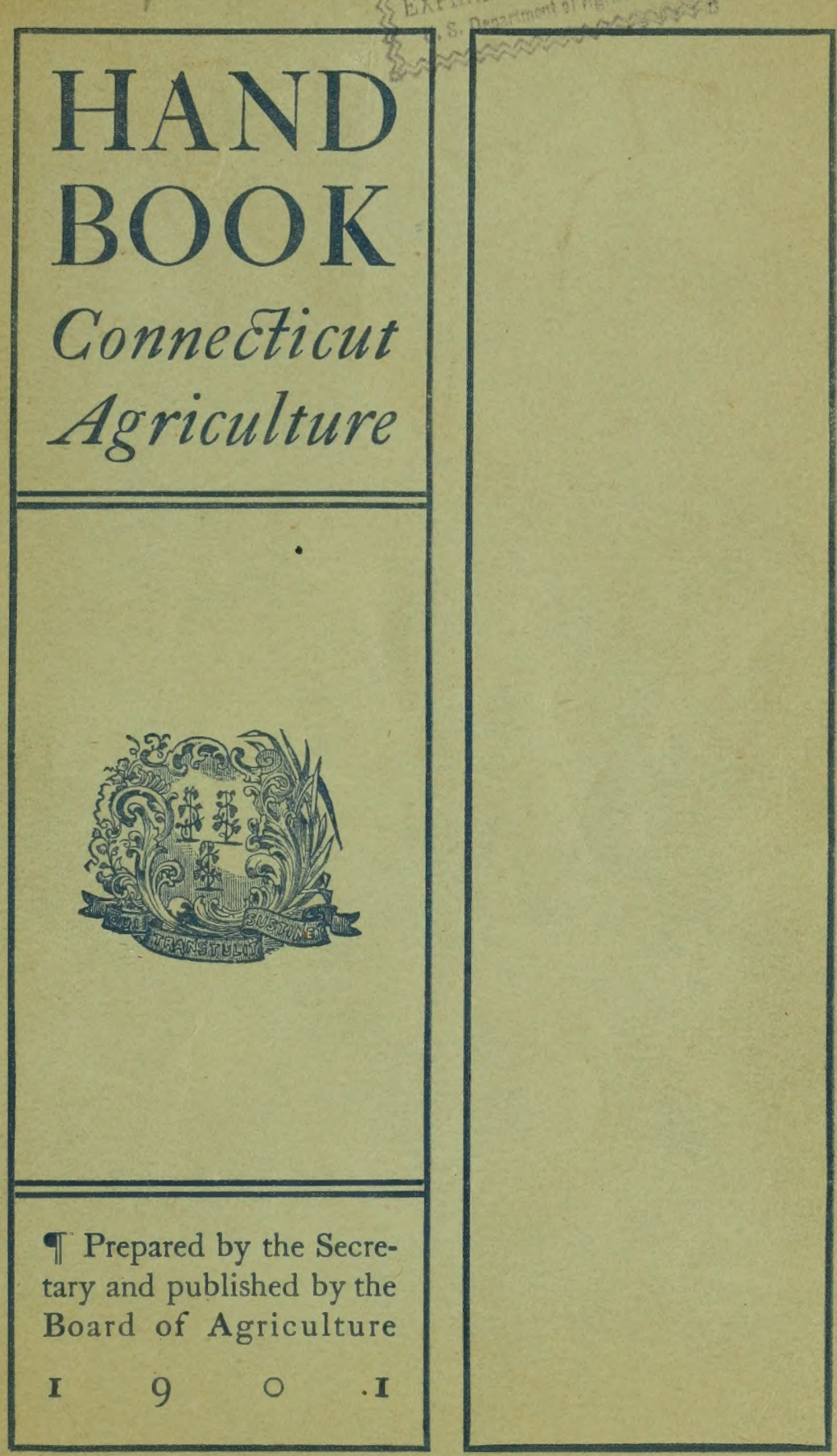





\section{H A N D B O O K of Connecticut Agriculture}

PREPARED BY THE SECRETARY AND PUBLISHED BY THE BOARD OF AGRICULTURE Nineteen Hundred and One

T. S. GOLD, Secretary

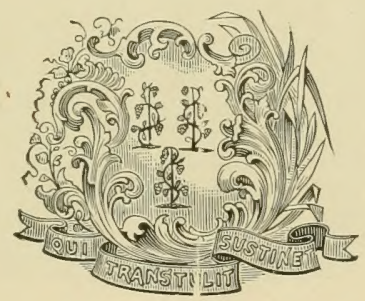

Printed by THE CASE, LOCKWOOD E BRAINARD CO., Hartford, Conn. I 99001 


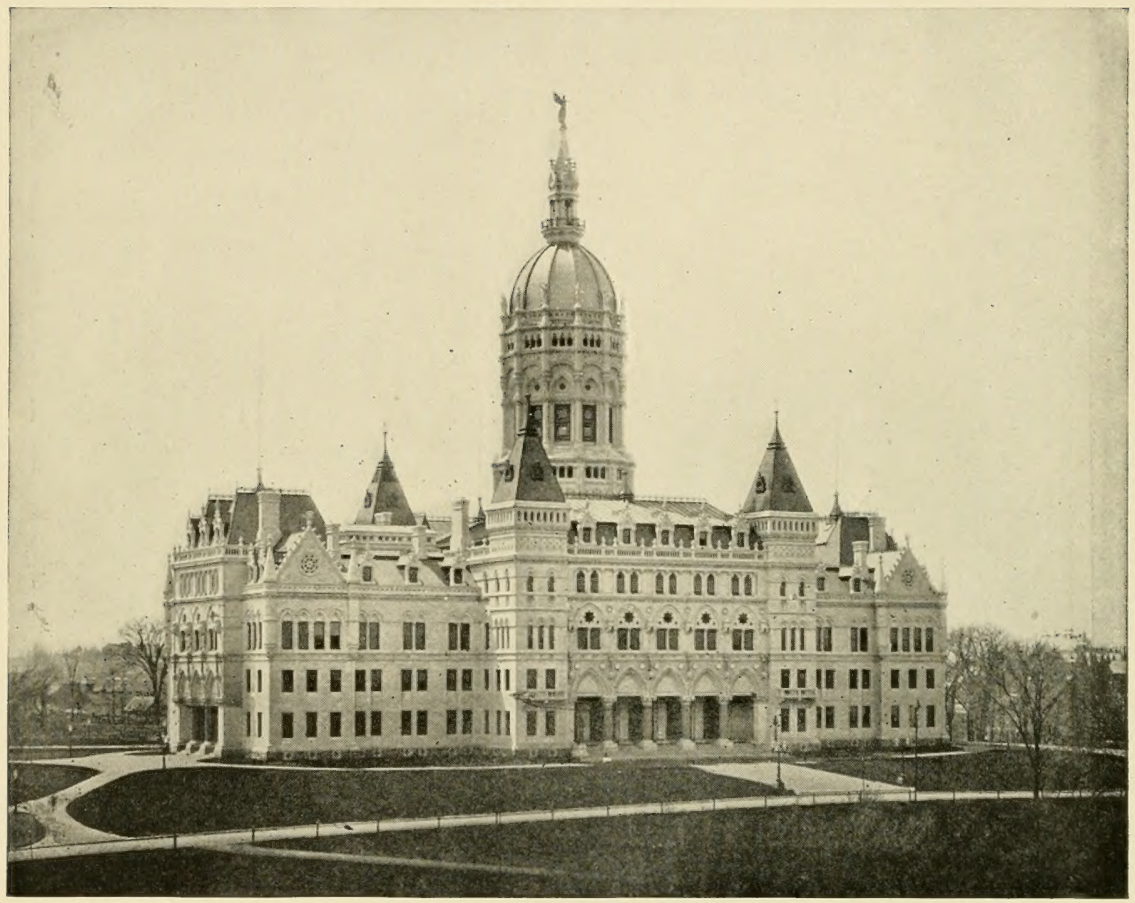

CAPITOL, HARTFORD.

Wn. H. Taylor.

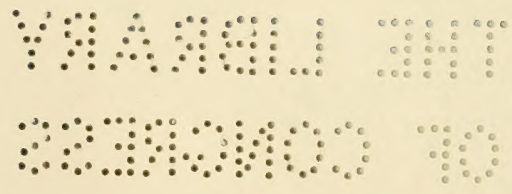




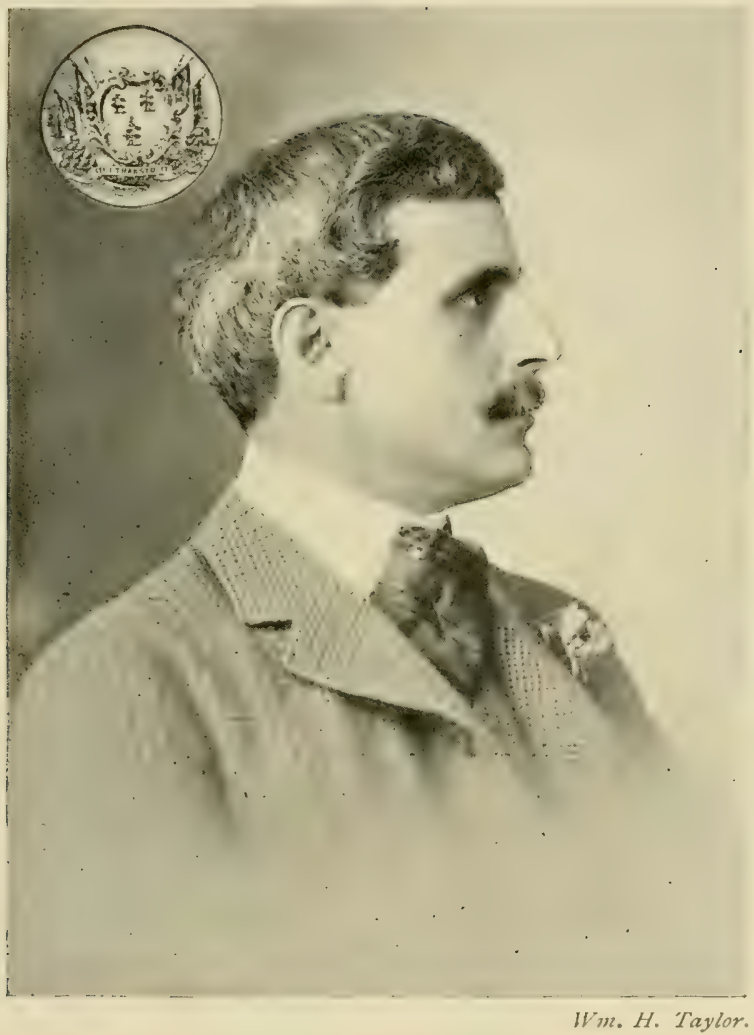

HoN. GEORGE P. MCLEAN, Governor of Connecticut. 


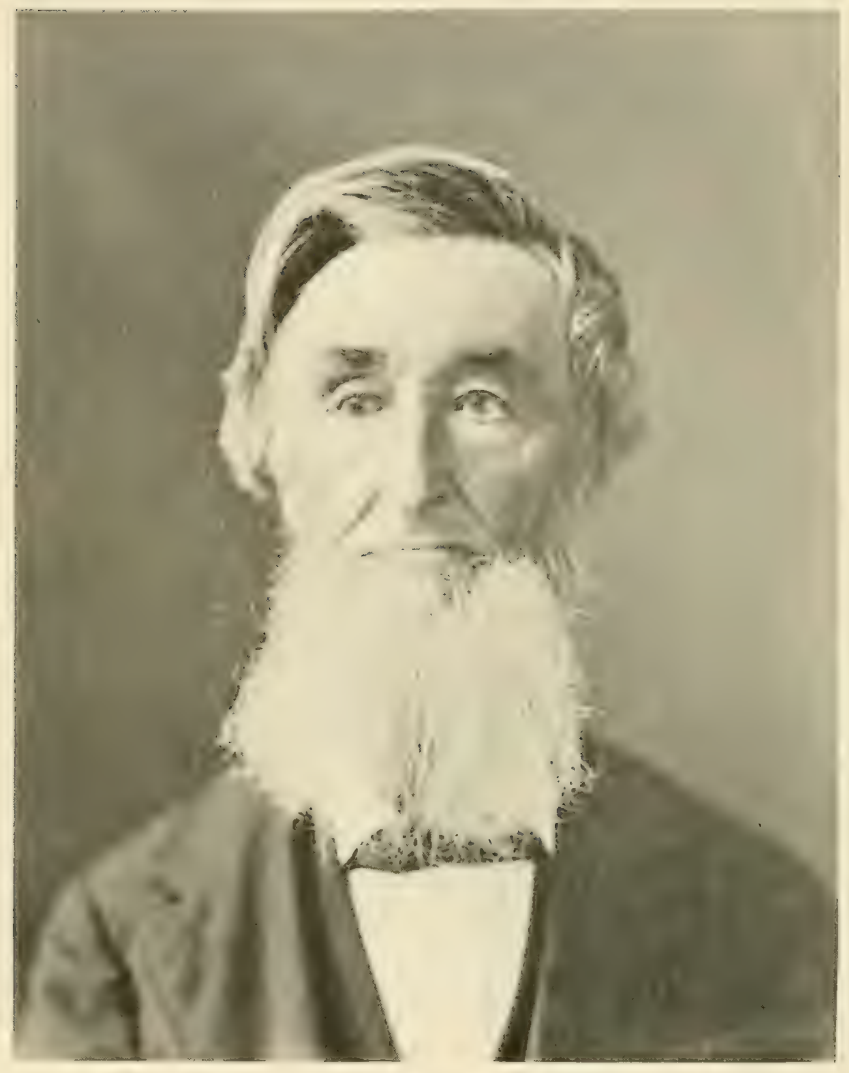

THEODORE SEDGWICK GOLD, Secretary of Connecticut Board of Agriculture. 


\title{
State of Connecticut
}

\section{BOARID OF AGRICULTURE}

\author{
Organized I\$65 Re-organized 1897
}

Gov. GEORGE P. McLEAN, President ex officio

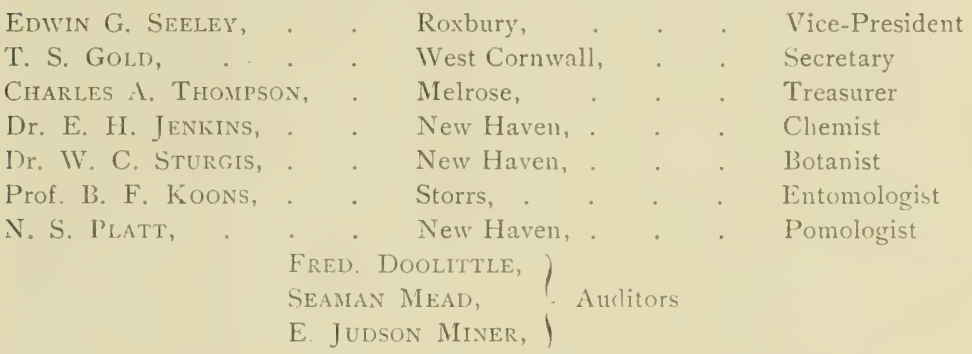

\section{Members Appointed by the General Assembly}

Edaund Halladay, Suffield, Hartford County

Fred'K Doolittle, Cheshire, New Haven County

E. Judson-Miner, Bozrah, New London County

Seanan Mead, Greenwich, Fairfield County

Nathaniel G. Willians, Broolilyn, Windham County

Edwin G. Seeley, Roxbury, Litchfield County

Ediert D. Hammond, Cromwell, Middlesex County

Charles A. Thompson, Melrose, Tolland County

Members Appointed by the Governor and the Senate

Charles L. Tuttle, IIartford

James F. Brown, North Stonington

Charles E. Chapman, Westbrook

IVERSON C. FANTON, IVestport 


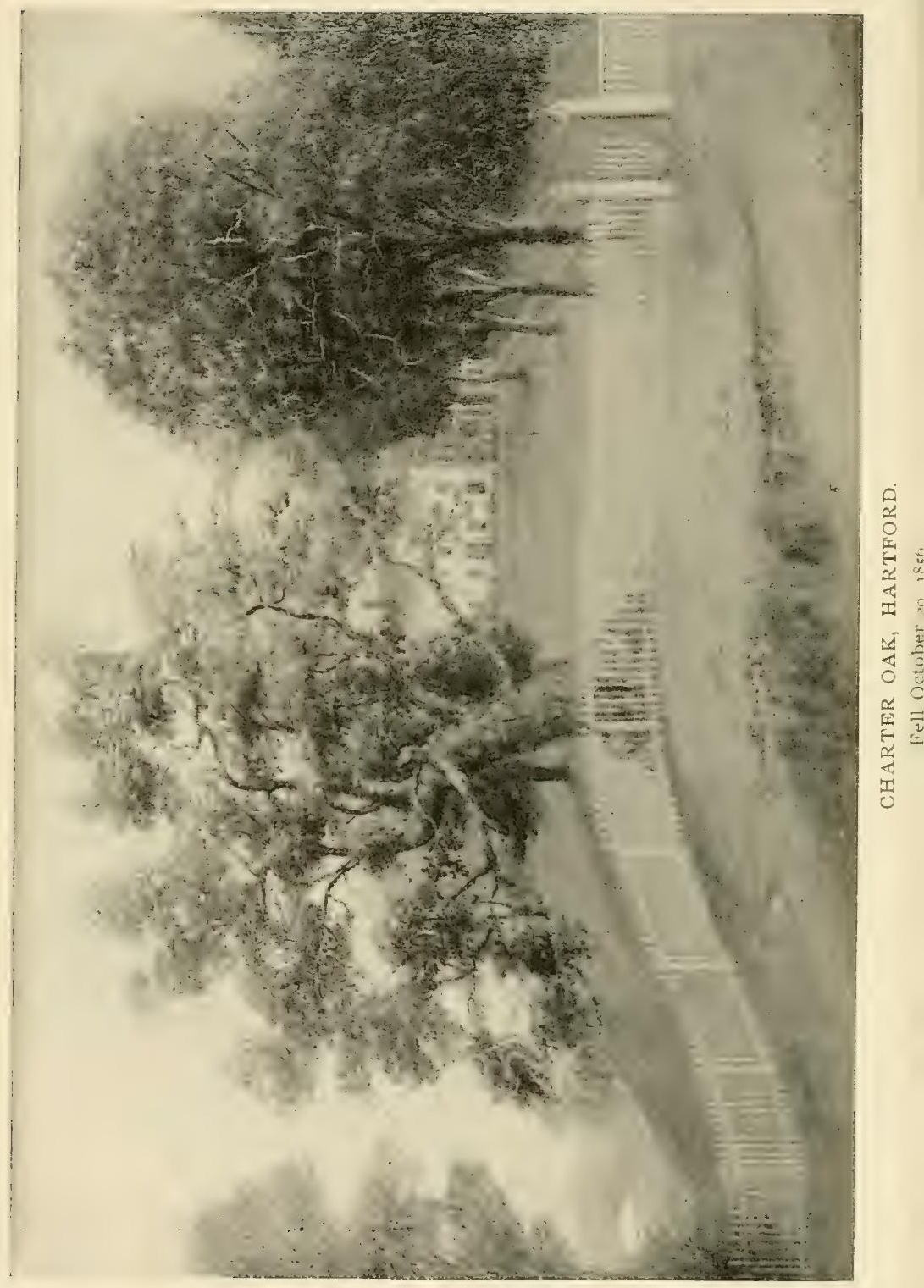




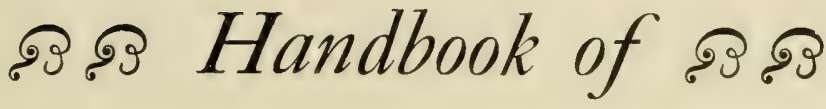 Connecticut Agriculture}

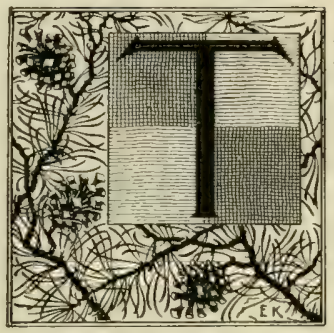

HE Board receives from the State $\$ 3,500$ annually, also the State prints 5,000 copies of Annual Report, not exceeding 350 pages.

The Board expends the State bounty in payment of salaries of secretary and treasurer, paying traveling expenses, in holding conventions or institutes, extra printing, and other expenses as required for the agricultural interests of the State. This current year twelve hundred dollars of this fund is expended in collection of exhibit for Buffalo and in extra printing.

Our thanks are due to Hon. Leverett Brainard for the exhibition at Buffalo of a full set to date of Reports of the Board, bound for his own library, and donated to the Agricultural College of Connecticut.

By the authority of the Connecticut Board of Agriculture, as secretary, I have been authorized to publish an Illustrated Handbook of Connecticut Agriculture. The task then seemed easy, as it was a familiar subject to me, but on study the material demands encyclopedic space, rather than the limited extent of a Handbook.

Credit is given and thanks are due to those who have furnished many of the illustrations and also descriptions of matters of interest. Otherwise the material is gathered from memory and historical records of common circulation.

Dear reader, kindly receive my well meant efforts, and overlook the omission of the thousand and one familiar scenes 


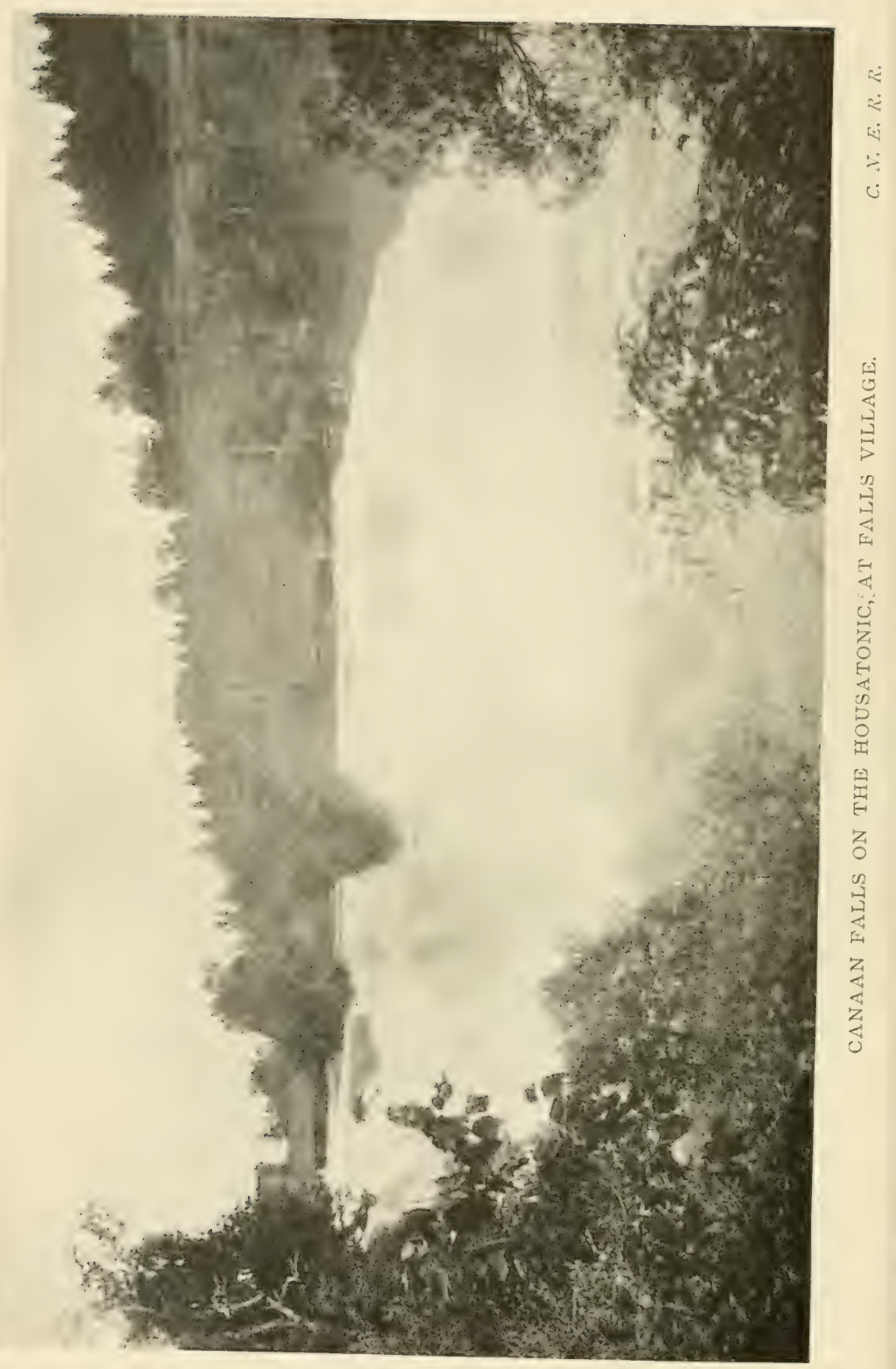




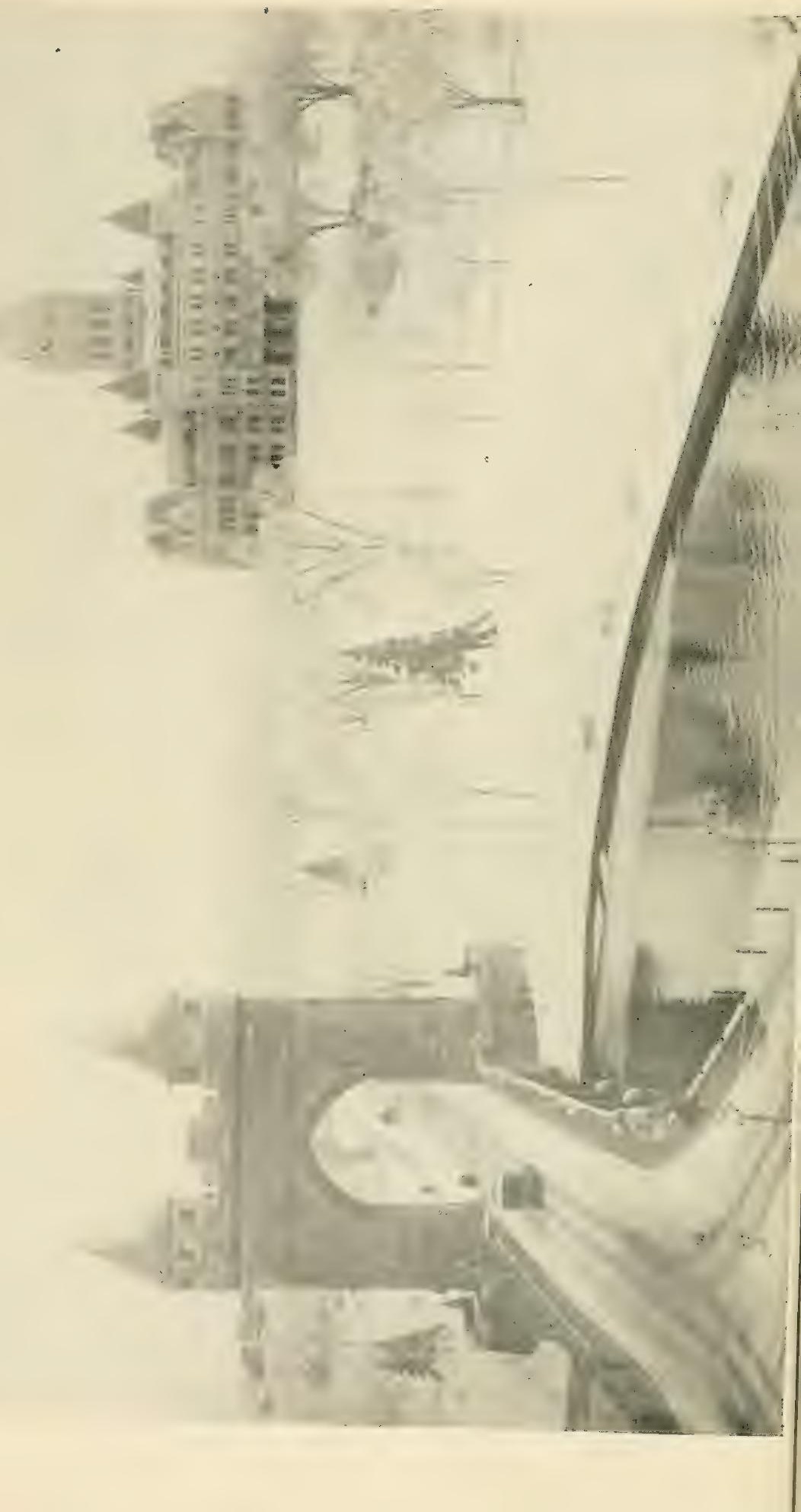


productions, industries, education, characteristics, can only receive each a single paragraph in this $\mathrm{Handbook}$ of Connecticut Agriculture, but there is such a natural interdependence between them all, with a reflex influence each upon every other that they cannot be omitted even if confined to a single line.

Connecticut is bounded on the south by Long Island

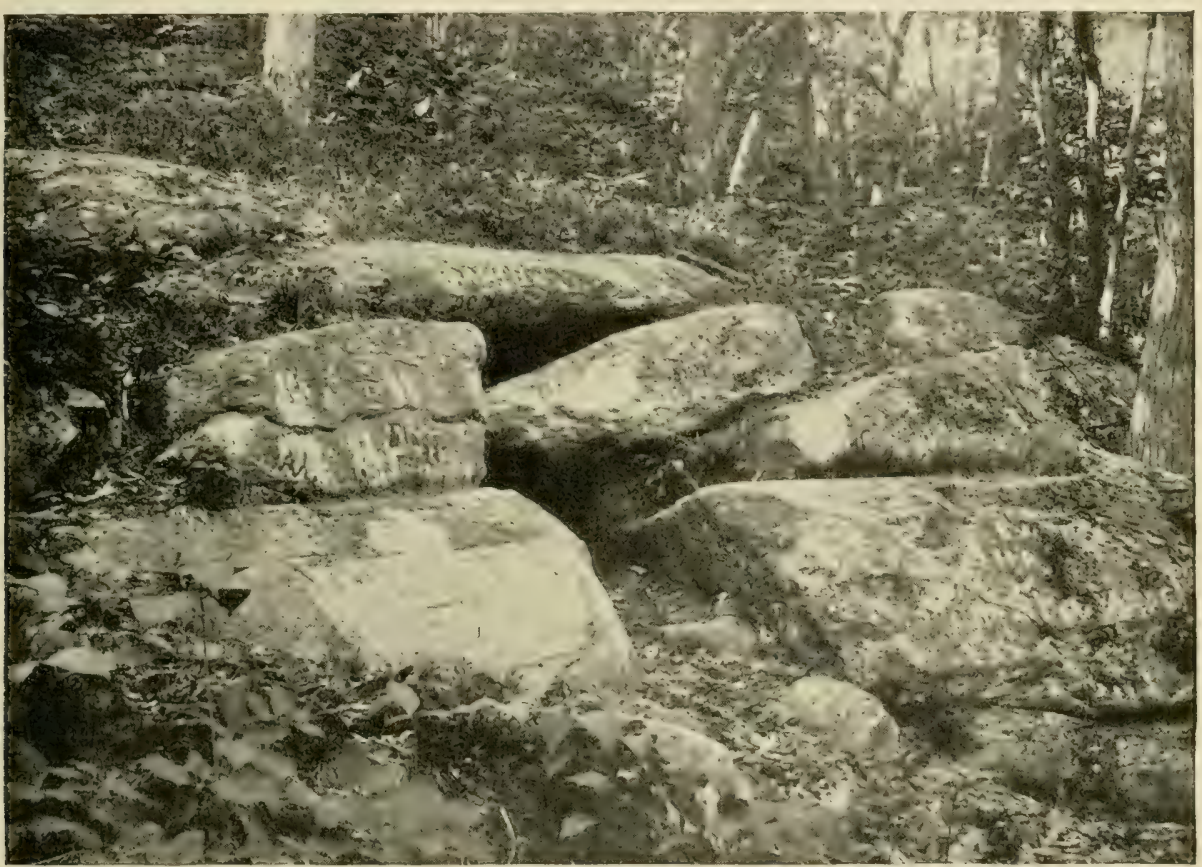

PUTNAM WOLF-DEN, POMFRET.

Sound, the noblest water way on the American coast, giving direct communication with New York, Providence, and the whole world beyond. Her daring navigators have hunted the whale, the grandest game on earth, to the Arctic regions, and have extended trade to the islands in the tropics, bringing back the treasures of sea and land.

The Connecticut river, the gem of New England, separating two states and intersecting two others, -

"No watery glades through richer valleys shine, Nor drinks the sea a lovelier wave than thine." 
The Housatonic, the river of the mountains, rising in the Berkshire Hills, meets the Sound at Stratford. The Thames, with the best harbor on the New England coast, is navigable to Norwich. These and their tributaries, fed by mountain

springs and lakes, furnish abundant water power, while the whole shore of the Sound abounds in oysters, clams, lobsters, etc., that make seaside resorts accessible to all.

Population of State, census of I900, 908,355, an increase of 21.7 per cent. in ten years.

The surface of the State is varied - hills and valleys, salt meadows on the coast, with intervales on borders of streams. Bear Mountain in Salisbury in the northwest corner of the State is 2,355 feet high, and there are many lakes in the State more than I,ooo feet above sea level. 


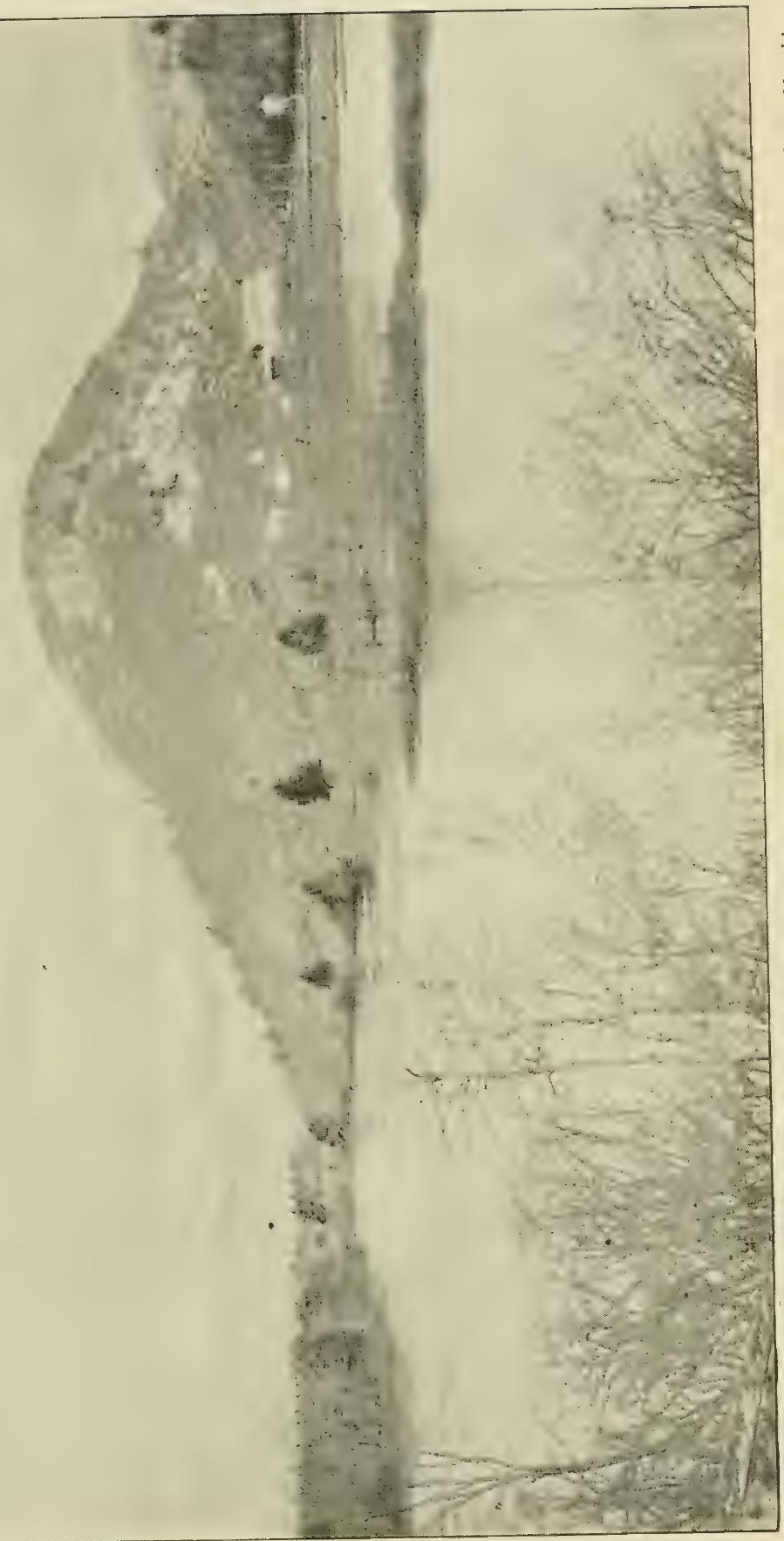


The soil, made up by the attrition and decay of granite, limestone, trap, and sandstone, furnishes the mineral elements needed for the growth of plants, held in keeping for future ages, and yielding their stores of locked-up wealth to the skill and industry of man.

With wood and stone for building and water power everywhere abundant, manufactures, first for home consumption, then for the world's use, have been an important feature in the progress of the State. The iron mines of Salisbury and other towns in Litchfield county, with furnaces and forges, even before the Revolution, were making the best iron in the country, furnishing much needed supplies of war material - a reputation still sustained.

Almost all mineral substances exist in the State, but so far only iron, marble, and limestone, other stones and clays, have become of commercial importance.

In naming the good things about Connecticut it would be unpardonable to omit the shad in referring to the "harvest of the sea," for everybody ought to know that the best shad always return to their Connecticut home. The success of the Fish commission in breeding this rover of the sea to maintain its abundance is very satisfactory.

Climate. Though somebody is always complaining of the weather, where will you find a more varied and healthful climate than in Connecticut? Sheltered from the blasts of the Atlantic by. Long Island and Cape Cod, by the mountain forests of Vermont and the Adirondacks from the Arctic waves, while we receive all the tonic we can bear, we share also in the kindly influence of the Gulf Stream and the zephyrs that sweep with more or less power through the pines of the south. If one wants wind, go to our hill tops; if shelter, seek some nook protected by forest covered hills and a grove of white pine-; its sighs will soothe while the roar of the storm on the hills marks the tempest which does not reach your arcadian retreat. One of our mountain brooks with its gentle murmur completes the scene, and it needs no landscape gardener to improve upon nature. 


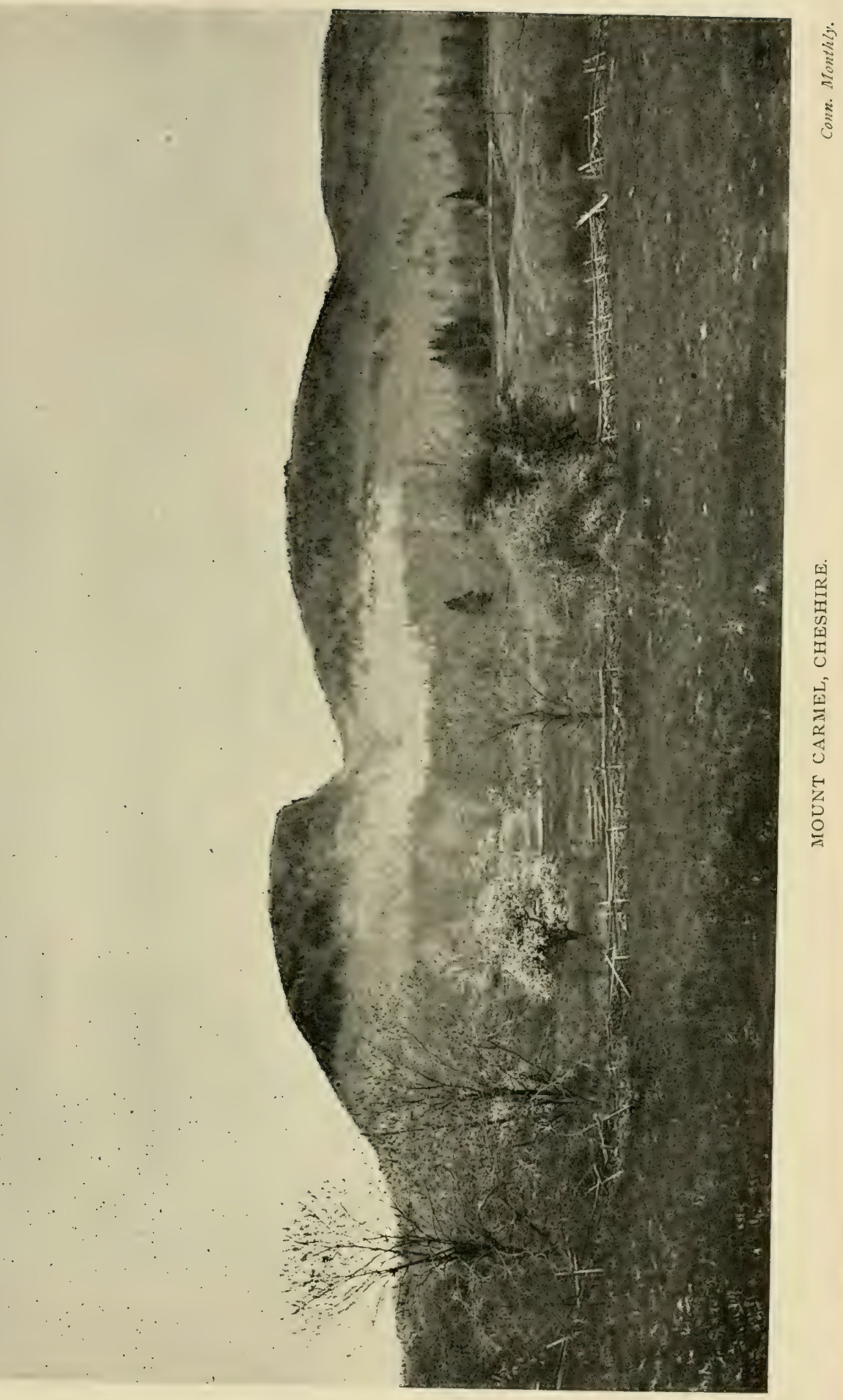




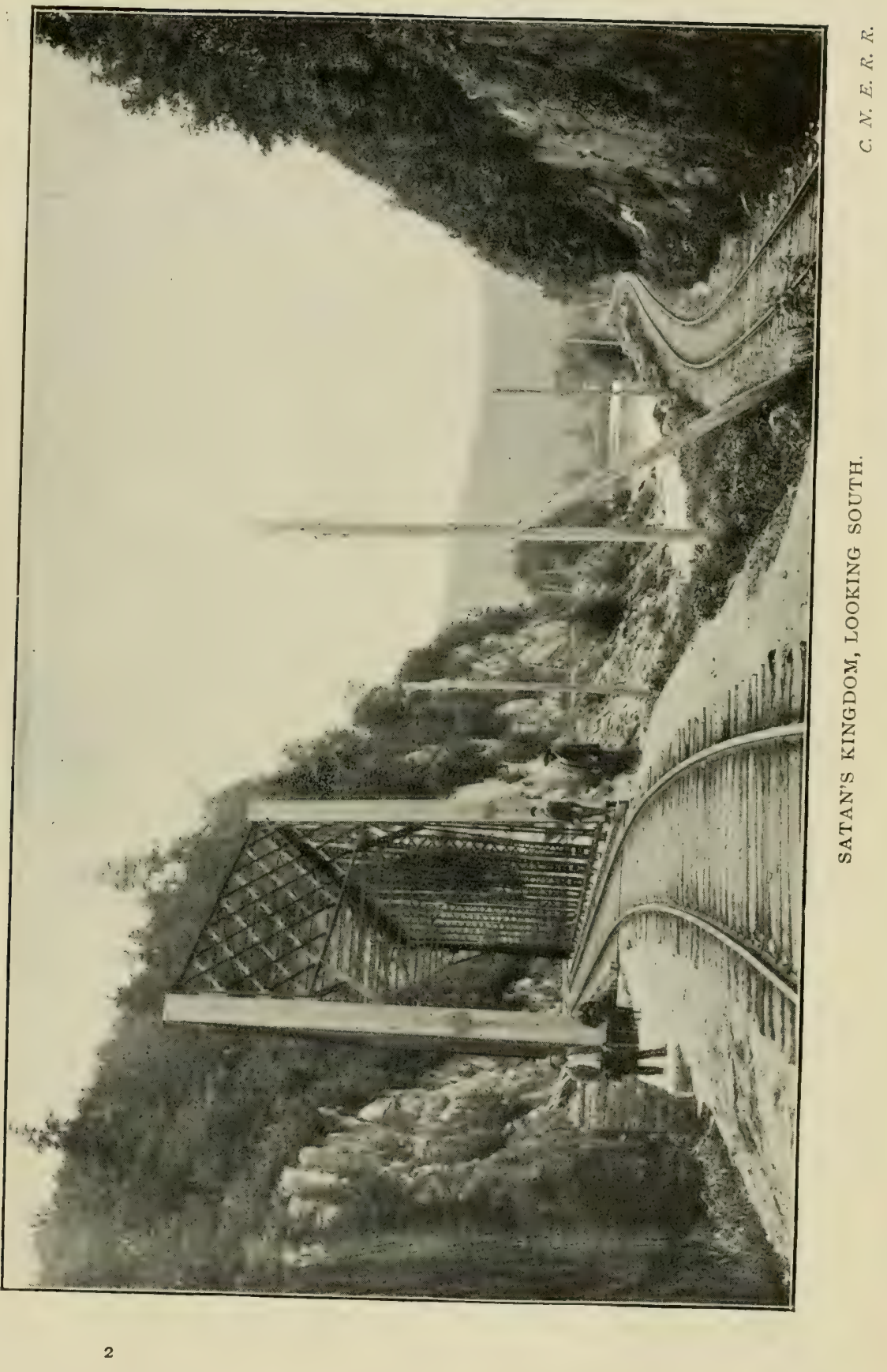


Agriculture in Connecticut has been directed in its location partly by soil and climate, but more especially by some accidental circumstances.

Thus tobacco finds a congenial soil in the valleys of the Connecticut and Housatonic rivers and their tributaries. Litchfield and Windham have led in the dairy, while the growth of cities and manufacturing villages has made demand not only for the products of agriculture that pertain to them,

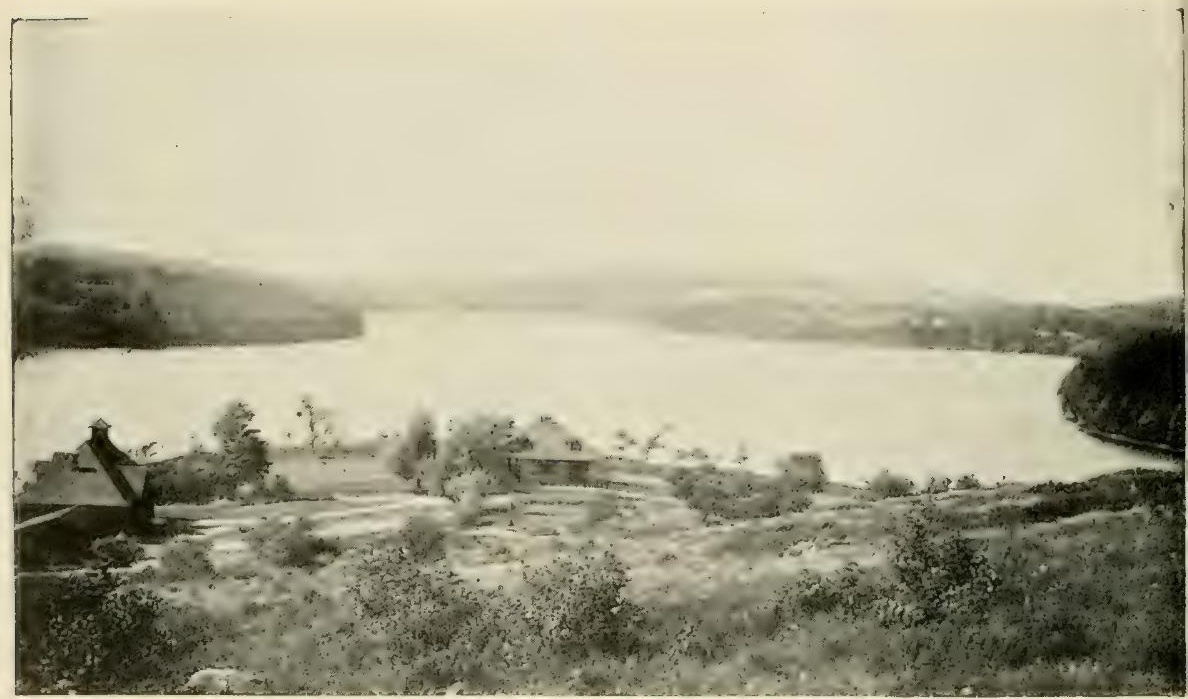

LAKE IVANGUM, NORFOLK'S WATER SUPPLY.

C. N. E. R.R.

but also for a supply of food that does not allow of transportation.

In manufactures, Litchfield county leads in iron, Fairfield county in hats, the Naugatuck valley in brass and copper, Eastern Connecticut took cotton, for was it not near Rhode Island?

\footnotetext{
"Did you ever go to Pawtucket? Lord, what a racket, Fifty crabs in a bucket."
}

These and other manufactures of wool, rubber, tools, and machinery have been scattered every where, water power being the chief element in controlling location till steam power has 


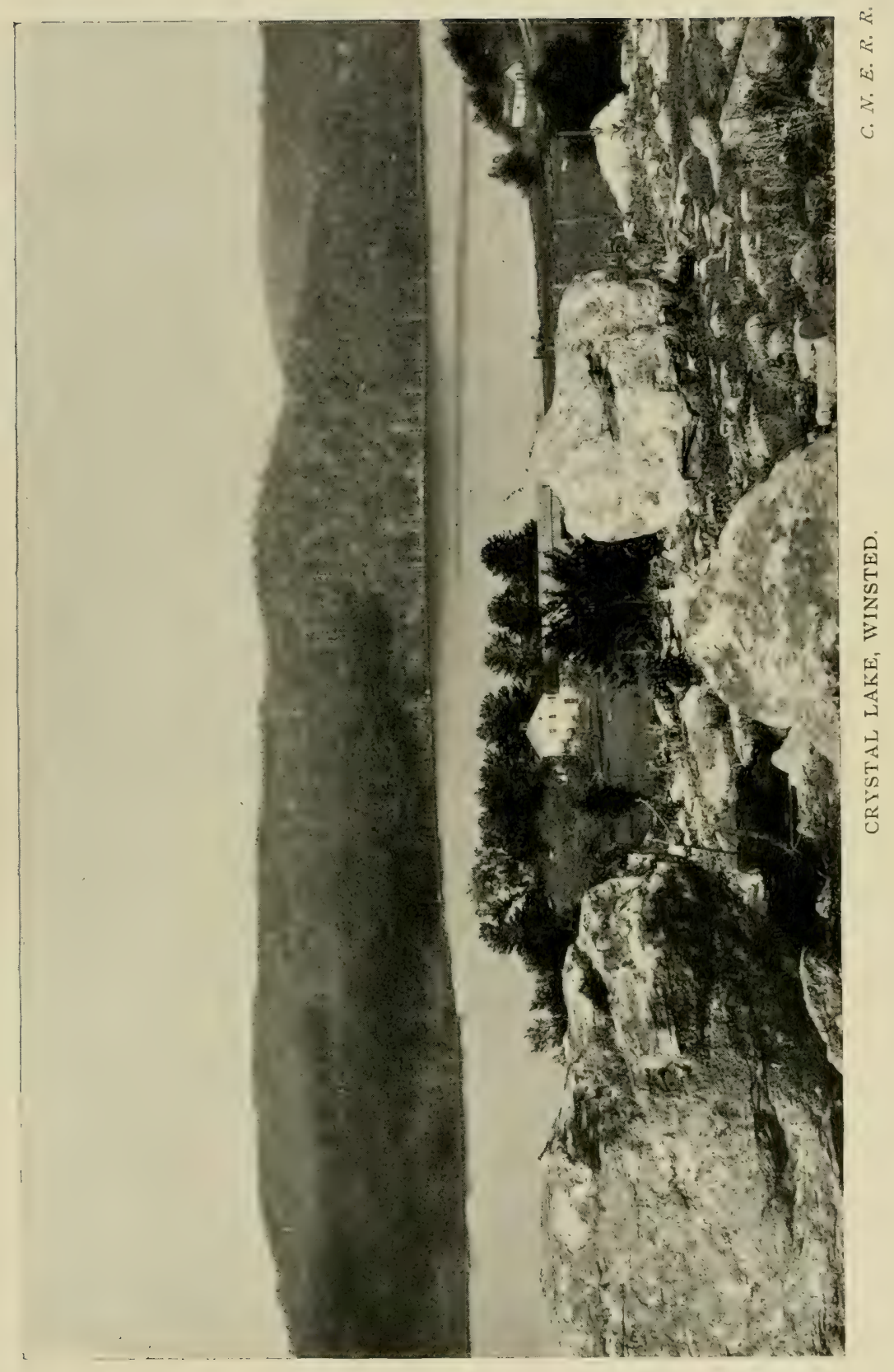


wrought great changes. It has been said that we "not only make everything in Connecticut, but we make the tools and machines to make it with.'

We cannot in this brief sketch notice everything of importance, nor in our illustrations justly balance and select all those scenes of the most interest, much less give the history which so largely adds interest to them, but we give samples only, and the traveler will find that every half mile will give him a change of view of mountain, valley, lake or river, orchard or meadow, village spire, farm house or walls of a factory where the hum of machinery marks a busy hive.

Agriculture has to do with and calls to its aid all the powers of nature and art; all sciences contribute to its success.

Every condition requires different treatment, and so if the reader does not find everything to his taste, remember that tastes differ, even if the matter is no better arranged than were the divisions on our Connecticut farms into meadow, plowland, pasture, and woodland; it is because they "come so by nature" and we can't help it. Diversity of material does not allow of classification except with great repetition. 


\section{THE CONNECTICUT AGRICULTURAL EXPERIMENT STATION.}

Board of Control.- His Excellency, the Governor, President; T. S. Gold, Vice-President, West Cornwall; E. H. Jenkins, Director; Wm. H. Brewer, Secretary and Treasurer; W. O. Atwater, Middletown; B. W. Collins, Meriden; Jas. H. Webb, Hamden; Edwin Hoyt, New Canaan.

Director.-E. H. Jenkins.

Advising and Consulting Chemist.- S. W. Johnson.

Chemists, - A. L. Winton, T. B. Osborne, A. W. Ogden, I. F. Harris, M. C. Williams.

Botanist.-W. C. Sturgis.

Horticulturist. - W. E. Britton.

In Charge of Work on Waste Land.- Walter Mulford.

Grass Gardener.- J. B. Olcott.

Clerk and Librarian.-Miss V. E. Cole.

Assistant Clerk.-Miss L. M. Brautlecht.

In Charge of Buildings and Grounds.-C. J. Rice.

Laboratory Helpers. - Hugo Lange, William Pokrob.

HISTORY .

Connecticut was the first State in America to establish an agricultural experiment station as a separate institution. A law was enacted on July 20,1875 , appropriating $\$ 2,800$ to Wesleyan University at Middletown, " $\$ 700$ per quarter for two years," beginning October I, I875, "to be used in employing competent scientific men to carry on the appropriate work of such a station." The university tendered free use of its laboratories and other facilities, and Mr. Orange Judd, a graduate and patron of the university, many years editor of the American Agriculturist, contr buted \$I,OOO toward the payment of expenses. Prof. W. O. Atwater was made director.

Before the expiration of the two years fixed for the duration of this station, the legislature established its successor as an independent and permanent institution of the State,“the Connecticut Agricultural Experiment Station," - by an act which became a law March 2I, I877, and appropriated $\$ 5,000$ annually for its support.

This station, by vote of its Board of Control, was opened July I, I877, at New Haven, with Prof. S. W. Johnson as 
director, in rooms placed at its disposal and fitted up for its use by the authorities of the Sheffield Scientific School of Yale College. The station occupied these quarters, rent free, for six years. In 1882 the annual appropriation was raised to $\$ 7,000$, and a special appropriation of $\$ 25,000$ was granted "for the purpose of buying a suitable lot and erecting thereon buildings and equipping the same for the permanent use of the station." The station then bought a piece of land of about five acres, which had on it a commodious house and a barn, and added a chemical laboratory. This place is still occupied by the station.

In May, I887, the Connecticut legislature accepted the provisions of the act of Congress, appropriating to each State annually the sum of \$ 15,000 for experimental work, and designated the board of control of this station to receive and expend one-half of this appropriation. In the same year a biological laboratory was built and equipped. In I 884 the annual State appropriation was made $\$ 8,000$ and so continued until I 895 , when it was raised to \$ I 2,500. In the latter year a special appropriation of $\$ 2,500$ was given for better equipping the laboratories and for other specified purposes.

In 1877 the staff consisted of the director and two chemists. The vice-director, Dr. E. H. Jenkins, was appointed in I 883. In I 888 a botanist was added to the staff, and a stenographer-clerk was employed. In I 894 a horticulturist was engaged, and from time to time laboratory helpers, sampling agents, and a night watchman have been added to the working force. After twenty-three years of continuous service, Professor Johnson retired from the directorship January I, I900, but retains his connection with the station as advising chemist. The vice-director, Dr. E. H. Jenkins, was appointed his successor.

\section{EQUIPMENT.}

The station buildings comprise an office building, chemical laboratory, biological laboratory, with three greenhouses at- 
tached, glass vegetation house for pot cultures in the warmer seasons, barn, and ice-house. The office building is a threestory, brick-filled frame house, containing the station offices and library and the dwelling of the director. It has two additions, each two stories high, which are the quarters of the superintendent of buildings and grounds. In the basement of the main building are the coal bunkers and a tubular boiler, from which the house, laboratories, and greenhouses are heated. The chemical laboratory is a two-story brick structure. On the first floor is the main laboratory, a samplingroom fitted with mills for grinding samples, and storage rooms adjoining. On the second floor are two laboratories and two small storage rooms. In the basement are two storerooms and various pieces of apparatus. 'The biological laboratory is a two-story frame house, in which the botanical, horticultural, and entomological divisions are accommodated. The basement contains a dark room for photography and a storage room. On the main floor are two workrooms, and on the second floor a museum. Connected with this building are a small plant-house for the use of the mycologist, a wooden frame greenhouse, and an iron frame greenhouse with a potting house and workroom attached, all heated by steam. These are devoted wholly to experimental work.

The station now owns about six acres of land, on which the buildings are situated. It keeps no live-stock for experimental purposes.

In the botanical division is an herbarium containing over 5,000 specimens of phrenogams and vascular cryptogams, and a number of mycological exsiccati. There are two collections of seeds of economic importance. The cabinet of insects contains over 3,000 specimens. There are also collections of minerals, rocks, and soils, fertilizers and fertilizer chemicals, native phosphates and potassic minerals, pure and adulterated food products, and charts, diagrams, tables, and lantern slides for illustrating addresses on agricultural subjects.

The station has sets of the more important agricultural, 
horticultural, chemical, physiological, and botanical journals and the essential books of reference on these subjects, numbering over 2,000 bound volumes, exclusive of pamphlets and station publications. Some of the books are quite rare and costly. The private libraries of the director, advising chemist, and botanist contain sets of other journals and many older works of reference, which, taken with the station library, very fully represent the useful literature of agriculture and the related natural sciences. While the station has no official or business connection with Yale University, the university library, numbering 266,000 volumes and I00,000 pamphlets; the special technical library of the Sheffield Scientific School, of about 5,000 volumes, and the special chemical libraries of the same school and of the other university laboratories are readily accessible to members of the station staff. The private libraries of many specialists connected with Yale University can also be consulted.

\section{LINES OF WORK.}

The station has, strictly speaking, no control duties. It is required to examine and report upon the composition of foods and fertilizers, but no prosecutions for violations of the laws are made by the station or its officers. The station is authorized to take samples of any lot or package of commercial fertilizer which may be in the possession of any dealer, and is required by statute to analyze annually at least one sample of every brand of commercial fertilizers sold in the State, to publish in its reports the results of such analyses, and to send at least two copies of its bulletins to every postoffice in the State.

The station is required by statute "at such times and places and to such extent as it may determine " to examine food products, which are defined by the statute as "anything used as food or drink by men, horses, or cattle." Any cases of adulteration must be reported to the dairy commissioner, who is charged with bringing prosecutions. The station 
must make an annual report of this work to the governor, not to exceed 400 pages.

The station is also authorized by statute to collect samples of concentrated feeding stuffs, and is required to cause at least one sample of each brand of feeding stuff collected to be analyzed, so far as to determine crude protein and fat, and annually to publish these analyses, with such additional information in relation to their composition, character, and use as may seem important.

Though not required by law, the station does all the chemical work requested by the State dairy commissioner, consisting chiefly of the analysis of molasses, butter, and vinegar, and furnishes expert evidence in court when needed by the commissioner.

The total number of samples of materials that have been examined in the chemical laboratory amounts to 24,630 .

Connecticut includes within its boundaries 22,264 acres of salt marsh and about I, OOO acres of brackish marsh, of which nearly one-fourth lie in the neighborhood of New Haven. In I 889 the station made an extended study of the botanical and chemical composition of the forage that grows on these marsh lands. Chemical analyses have also been made for the purpose of learning something of the agricultural value of swamp muck or peat, soils, marine mud, seaweeds, limestones, maize raised in Connecticut, hay, and a few other substances.

The station began the cultivation of grasses in I886. Mr. J. B. Olcott was employed to collect roots of any species or variety of grass that appeared useful or promising. From these and from seeds procured from various sources the station garden had, in 1887,650 sods and 219 drills or plats raised from seed, all distinct in immediate origin and mostly distinct in appearance. With the idea that grasses, like fruit trees, have developed into many different varieties, Mr. Olcott has made six journeys of exploration with the sole purpose of collecting cultivated grass plants and seeds whose 
repute or appearance would indicate special value for use in pastures, meadows, or lawns. He thus visited some of the best grazing districts of Connecticut and Rhode Island, Pennsylvania, various Southern, Central, and Pacific States, Great Britain, Denmark, Austria, Switzerland, France, Hawaii, and Australia, and through correspondents received sods from other States and countries. It being impossible to care for these collections at the station, where the soil is not adapted to grass, Mr. Olcott undertook to transplant the most promising grasses to favorable ground on his farm, near South Manchester. Since I $890 \mathrm{Mr}$. Olcott has devoted himself untiringly to the care of the South Manchester grass garden of about two acres area, where he has had growing in pure cultures 3,022 distinct grass plats, comprising 600 sods from station grounds at New Haven, 793 sods collected in the United States, I,005 from Europe, 125 from Australia and the Hawaiian Islands, 250 miscellaneous, and 250 plats from trade seeds. Of these $\mathbf{1}, 500$ are now under observation and about the same number have been destroyed as inferior or unfit for culture.

An important investigation has been the study of the vegetable proteids, on which Dr. Osborne, with an assistant, has been continuously engaged for eight years. Subjects of this investigation have been mostly seeds. These results, though mostly technical, have already found application in the manufacture of flour.

The organism causing the scab of potatoes (Oospora scabies) was isolated and described at this station by Dr. Roland Thaxter. A new species of Phytophthora has been described, which has caused extensive damage to Lima beans. The methods of infection have been studied and preventive measures suggested. A considerable number of new species of fungi of less economic importance have also been described.

The nature and cause of "pole burn," a very destructive disease to which leaf tobacco is liable while curing, and its 
prevention by the use of suitable devices for ventilating by means of artificial heat, have been studied. Studies on the curing and fermentation of wrapper-leaf tobacco are now in progress.

Investigations are in progress with the object of determining the cause of "calico," a destructive disease of growing tobacco. It has been ascertained that the disease is purely physiological, and experiments indicate that the use of lime upon soils where "calico" is liable to occur is attended with good results.

The effect of shading growing tobacco plants has also been under trial, and some interesting and possibly important results with respect to the texture of the leaf have been obtained.

Experiments with fertilizers in the culture of carnations have been a prominent line of work in the horticultural division.

For several years the disease known as onion smut, due to the fungus Urocystis copulae, which seriously threatens onion growing in Connecticut, has been a subject of study. In I889 Dr. Thaxter found that when onion seed was sown in soil that has been impregnated with Urocystis cepulae, the young plants were infected underground, and if the fungus did not become manifest in them shortly after they appeared above the soil, they were not subsequently affected by it. Dr. Thaxter noted that "the fact of subterranean infection is further confirmed by the absence of smut on sets and seed onions, as well as on transplanted seedlings." Dr. Sturgis has more recently shown that when onion seed is sprouted in clean soil in hotbeds, and the seedlings transplanted into smutty land, the onions entirely escape infection.

Extensive studies have been made on the chemical composition of maize as affected by fertilizers and by open and close planting. For six years the availability of various forms of nitrogen has been studied in a large number of pot cultures, with various soils, fertilizers, and conditions. 
This station has from the first done much work in improving laboratory methods, operations, and apparatus. Among the pieces of apparatus devised by the station workers which have proved satisfactory are a fat extractor, a hydrogen generator, gas dessicator, apparatus for drying in hydrogen, aliquotimeter, apparatus for determining nitrogen by the absolute and by the Kjeldahl methods, an oven for drying large samples (e. g., maize stalks, coarse grasses, or other forage plants), and apparatus for determining nitric acid (modification of Schulze-Tiemann apparatus).

\section{DISSEMINATION OF INFORMATION.}

The station has issued $\mathrm{I} 33$ bulletins and 24 annual reports. The publication of the annual report, not to exceed 400 pages, is done at State expense. It contains a full account of all the work done by the station during the year and includes the matter published in bulletins. The edition published at public expense is now limited by law to 7,000 copies. The station has frequently printed large numbers of additional copies to meet the demand.

Prof. S. W. Johnson is the author of "Essays on Peat, Muck, and Commercial Manures," "Peat and Its Uses as Fertilizer and Fuel," "How Crops Grow," and "How Crops Feed," which were written previous to the establishment of the station. The two books last named have been translated into French, German, Swedish, Russian, and Japanese, and have been used as text-books. "How Crops Grow" was reprinted in England and translated into Italian, and a revised edition was issued in New York in I89I. Dr. H. P. Armsby, while on the staff of this station, wrote his "Manual of Cattle Feeding." Numerous papers have from time to time been published in scientific journals by members of the station staff. Messrs. Jenkins and Winton made a "Compilation of Analyses of American Feeding Stuffs" that was published as a bulletin of the Office of Experiment Stations.

The mailing lists are very large and constantly under re- 
vision. The-station correspondence is over 3,500 letters' a year. The members of the station staff are frequently called upon for papers or addresses before the annual meeting of the State Board of Agriculture, the Pomological Society, and the Dairymen's Association, and at farmers' institutes, as well as meetings of the county and subordinate granges.

GENERAL RESULTS OF WVRK.

The Connecticut State Station has been a leader in the establishment of fertilizer inspection in this country and in investigations regarding the use of fertilizers and their effect on the composition of the crop. The benefits of this work have been very great and their influence has been widely extended. As a result of the constant supervision of the fertilizer market, fraudulent fertilizers have long been practically excluded from the State. Although food inspection has been in operation for only four years, a decided decrease in the extent of adulterations is already noticed.

Many of the co-operative experiments undertaken by this station have been highly successful, and in this as well as in other ways, much has been done to educate practical cultivators of the soil in matters pertaining to the application of chemistry and other sciences to agriculture.

In recent years the investigations on tobacco have helped to enable Connecticut growers to improve the quality, and hence maintain a relatively high price for their wrapper-leaf tobacco.

Through information and instruction given in its publications, and more particularly by the personal supervision of the station staff and practical demonstrations made in various parts of the State, the use of insecticides and fungicides, and spraying with improved machinery, were first introduced into Connecticut, to the very great benefit of the fruit and vegetable industries.

The larger nurseries of the State are annually inspected by station officials for injurious insects or fungus pests. On 
being notified of the appearance of any such pest in any part of the State, a member of the staff at once visits the place to give what help is possible.

Largely through this station, the very crude and unfair methols of payment for milk and cream delivered by farmers to creameries in the State have been replaced by a rational system based on the Babcock test.

Dr. E. H. Jenisins, Director.

\section{THE CONNEC'TICUT AGRICULTURAL COLLEGE, STORRS, CONN.}

In education as connected with agriculture shall we begin with the common school and Webster's spelling book, in which probably more persons have "learned their letters" than in any other book in the world, or with "Yale Univer-

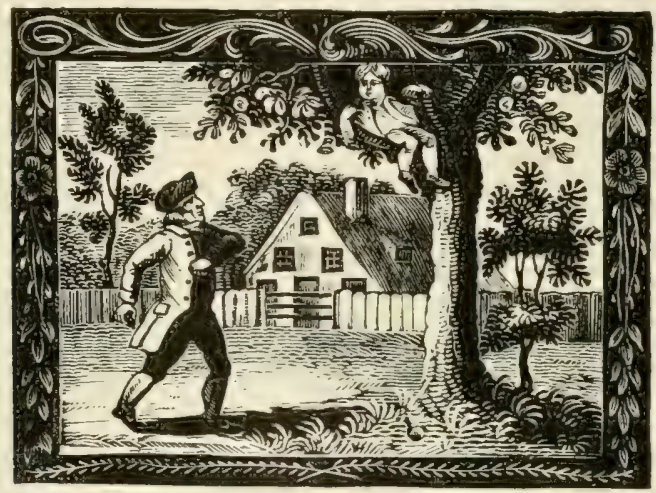

THE RUDE BOY AND THE FARMER.

Noah Webster's Spelling Book.

sity," the crowning glory of the State in all learning, and from the earliest days a "patron of husbandry" ? But space forbids to take up the thread of history and show how they blend with agriculture - controlling and controlled by it.

From Yale, Wesleyan, and Trinity streams of light have permeated all society, and agriculture has shared the benign influence. The new movement for more practical agricultural 


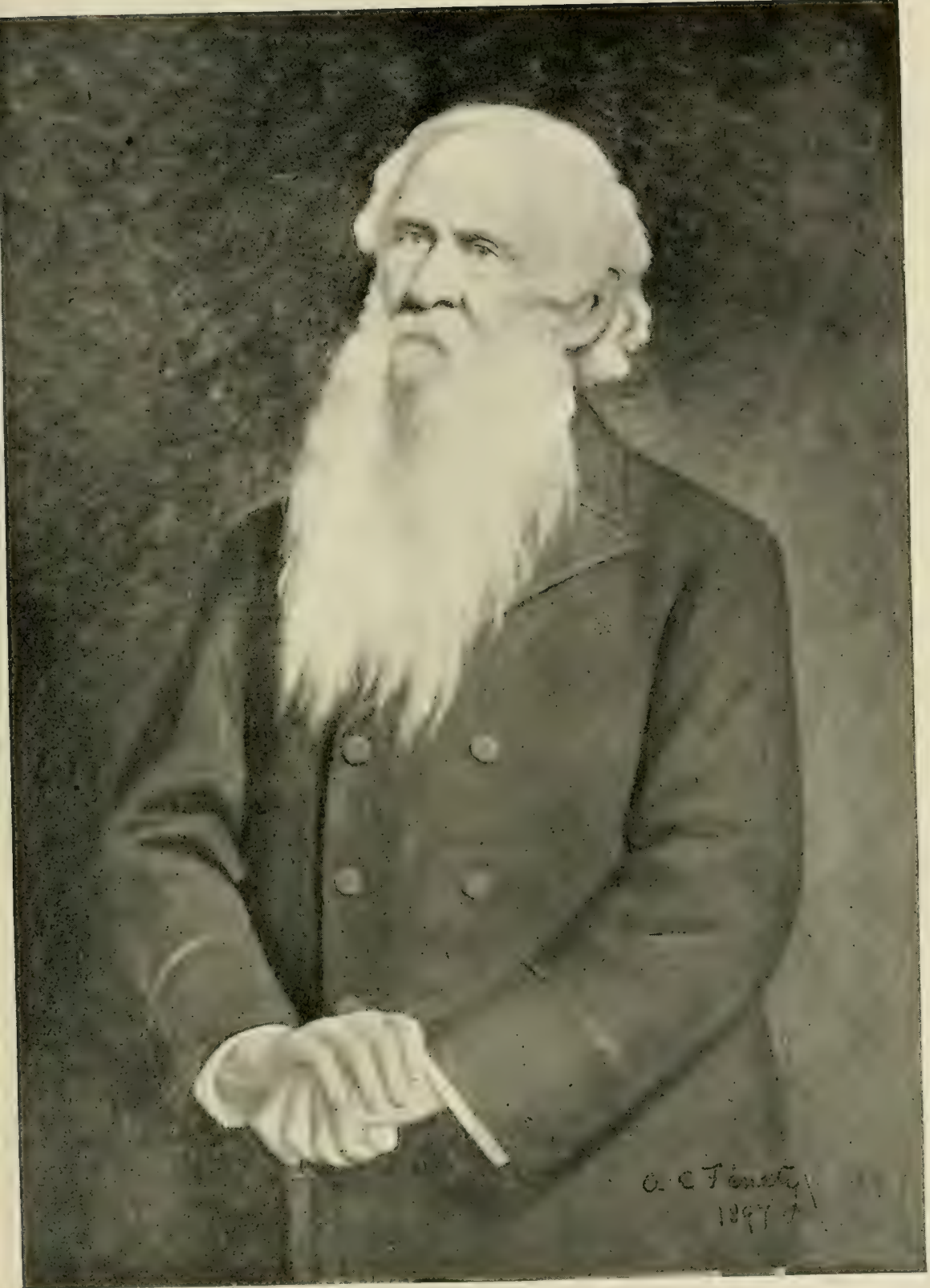

HENRY BARNARD, LL.D.,

Conn. Monthly.

The veteran educator, widely known for his work for common schools. He died July 5 , Igoo, in the house in which he was born, 89 years ago. 
education, taking form in agricultural colleges and experiment stations, will not detract from their power and influence, but as co-laborers in educating and elevating the world, are welcomed in the wide field where man works with body, mind, and soul - in the great harvests of the world

In answer to a long felt want the Storrs Agricultural School at Mansfield was organized in I88I. Messrs. Charles and Augustus Storrs gave a farm of 170 acres with buildings and $\$ 6,000$ for equipment, to give scientific and practical education for farm life.

By act of the General Assembly in 1883 this became the Storrs Agricultural College with co-education. The funds derived from the National Government were appropriated to the college. In I 899 the name was changed to the Connecticut Agricultural College.

The annual report and catalogue gives in full, courses of study and equipment.

Trustees.-His Excellency the Governor, George P. McLean, President ex officio; Hon. W. E. Simonds, Hartford, Vice-President; T. S. Gold, West Cornwall ; W. D. Holman, West Willington, Treasuerer; S. O. Bowen, Eastford; Hon. E. S. Henry, Rockville; Geo. A. Hopson, Wallingford, Secretary; M. M. Frisbie, Southington; E. Halladay, Suffield; E H. Jenkins, Ph.D., New Haven.

\section{FACULTY AND INSTRUCTORS.}

George W. Flint, A.M., President, Professor of English and Mathematics.

Benjamin F. Koons, PH.D., Professor of Zoölogy, Geology, and Entomology.

Charles S. Phelps, B.S., Professor of Agricultural Science.

Alfred G. Gulley, M.S., Professor of Horticultural Science.

Rufus W. Stimson, M.A., B.D., Professor of Rhetoric, Ethics, Elocution, and English Literature.

Nelson S. Mayo, M.S., D.V.M., Professor of Anatomy, Physiology, and Veterinary Science.

Charles A. Wheeler, A.B., Professor of Mathematics, History, and Free-Hand Drawing.

Henry R. Monteith, A.B., Professor of English, History, Civics, Political Economy, and Mathematics.

Camprell E. Waters, Ph.D., Professor of Chemistry and Physics.

Henry S. Patterson (Master Mechanic), Professor of Mechanics and Mechanical Drawing.

Marcia G. Greenough, A.B., Ph.B., Professor of Domestic Economy. 
Charles L. Beach, B.S., Assistant Professor of Dairying and Cattle Breeding.

Henry A. Ballou, B.S., Assistant Professor of Forestry, Botany, and Military Science.

William A. Stocking, JR., B.S.A., Farm Superintendent and Instructor in Agriculture.

Robert Dallas, Instructor in Poultry Culture.

Charles E. Myers, Instructor in Farm Accounts and Business Methods.

Thomas D. Knowles, Instructor in English, Mathematics, History, and Physical Culture.

Charles E. Myers, Secretary of the Faculty.

Lucius P. Chamberlain, College Steward.

STORRS AGRICULTURAL EXPERIMENT STATION.

[Officers same as Connecticut Agricultural College.]

Station Staff.-W. O. Atwater, Director; C. S. Phelps, Vice-Director and Agriculturist; F. E. Singleton, Secretary; A. P. Bryant, Chemist; J. F. Snell, Assistant Chemist; H. L. Garrigus, Assistant Agriculturist.

The Station is located at Mansfield (P. O. Storrs), as a department of the Connecticut Agricultural College. The chemical and other more abstract research is carried out at Wesleyan University, Middletown.

\section{HISTORY.}

At the time the Act of Congress of March 2, I887, known as the "Hatch Act," was passed, which provides that \$ 5,000 be appropriated annually to each State for agricultural experiment stations, there was, in Connecticut, a station which had begun its work in Middletown, but had been transferred to New Haven. The General Assembly of Connecticut, of 1887 , provided that the appropriation to the State under the provision of the above act should be divided, onehalf being placed in charge of the Board of Control of the State station at New Haven, and the other half in charge of the Storrs Agricultural School. (now the Connecticut Agricultural College) in the town of Mansfield, for the purpose of establishing and maintaining an experiment station in connection with the school. In March, I888, this fund became available and the Storrs Station was established, with Dr. W. O. Atwater, professor of chemistry in Wesleyan University, as director. The Wesleyan University again offered labora tory facilities for chemical and other research in Judd Hall 


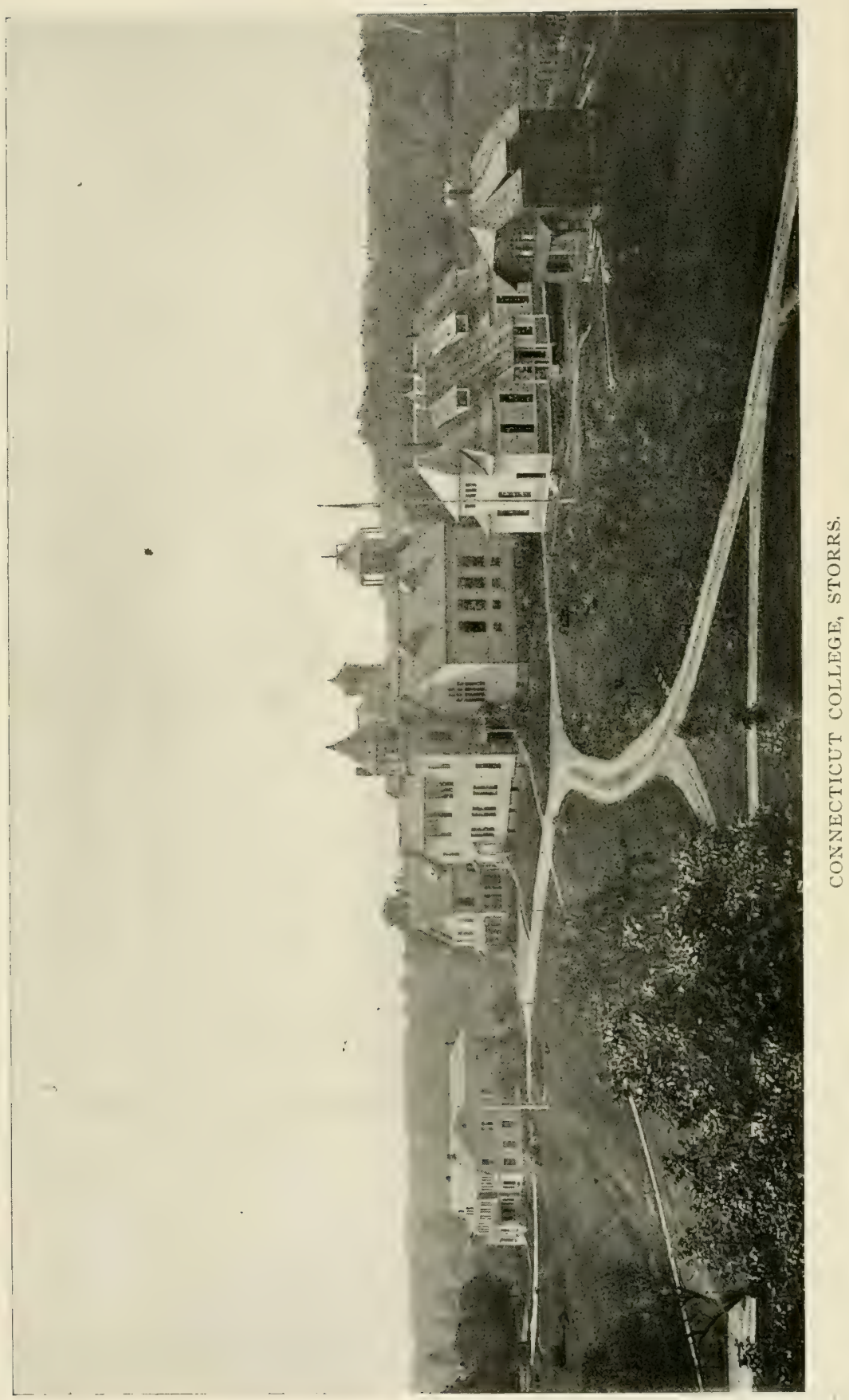


of Science, where, in October, I875, had been established the first State experiment station in this country, afterward removed to New Haven.

The farm and farm appliances of the Agricultural School were placed at the disposal of the station for experimental purposes. Prof. C. S. Phelps, of the Agricultural School, was appointed as agriculturist of the station and vice-director, and was placed in charge of coöperative field and dairy experiments. Dr. H. W. Conn, professor of biology in Wesleyan University, undertook and has since carried out, on behalf of the station, investigations in dairy bacteriology. Mr. C. D. Woods, who had previously been associated with Prof. Atwater at Wesleyan University, was the first chemist of the station, and continued in that position until he was called, in 1896 , to be professor of agriculture in the University of Maine, and director of the Maine Experiment Station.

The total annual income of the station is less than that of any other station in the country, with one exception. It consists chiefly of the $\$ 7,500$ appropriated by Congress, and $\$ \mathbf{1}, 800$ appropriated by the State. Occasional gifts have been received from private sources for carrying on special investigations. In addition to these, the station formerly cooperated with the U.S. Department of Labor in carrying out dietary studies, and now coöperates with the U. S. Department of Agriculture in its investigations on the food and nutrition of man, and is thus enabled to increase its efficiency and usefulness.

The trustees of the school to whom was entrusted the care of the fund appropriated by Congress have allowed the director, Prof. Atwater, to plan and carry out the work of the station according to his own judgment, qualified as he was as a successful pioneer in work of this kind. A portion of the work done has been in continuation and development of inquiries begun by Prof. Atwater in the chemical laboratory at Wesleyan University before the Storrs station was established. Among these was a study of the fixation of free 


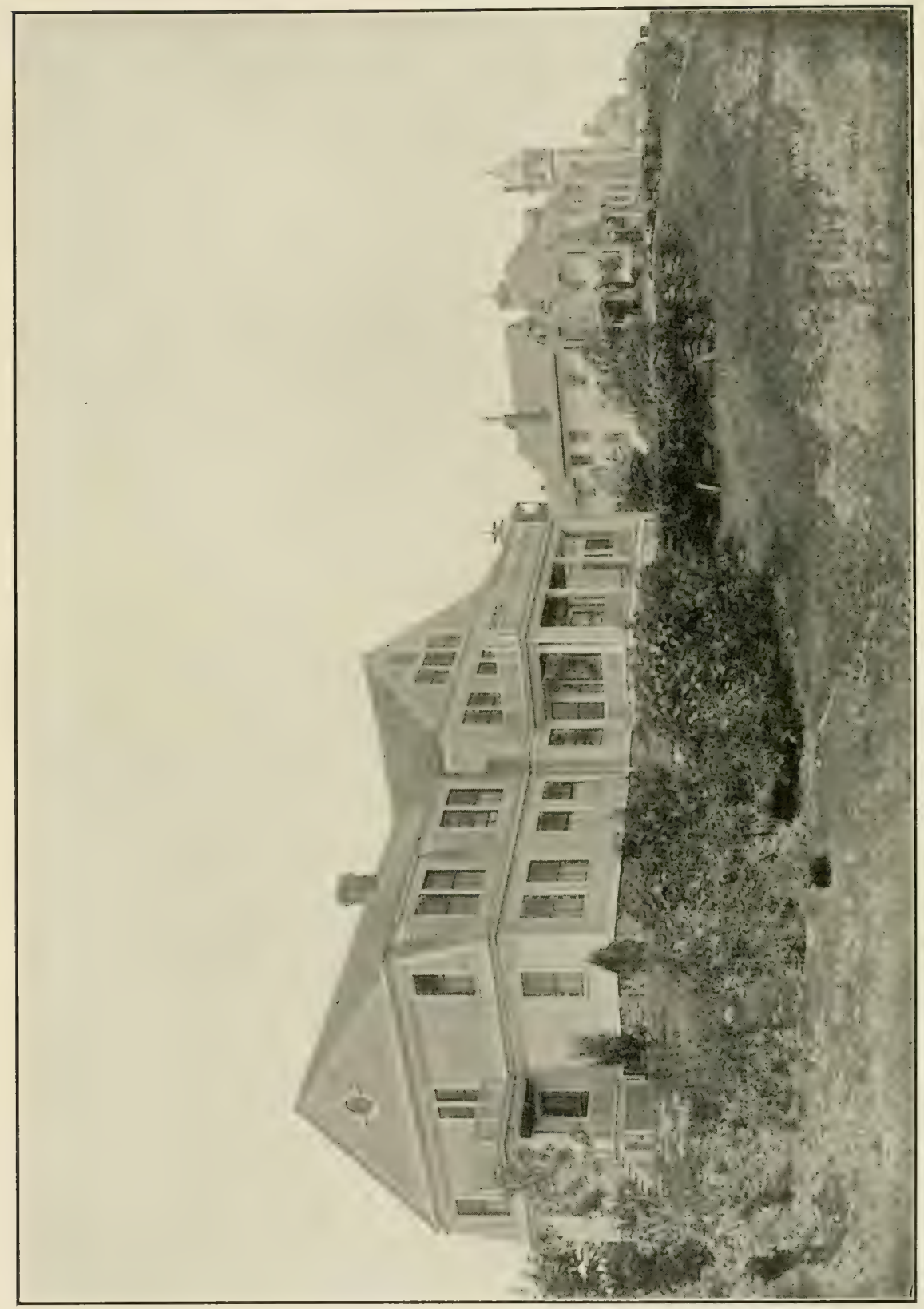


nitrogen by leguminous plants. The work of the station in this line has done much to increase our knowledge of this important subject. Some of the investigations undertaken by the station in its early years were continued only a short time, while others have been continued year after year ever since they were first undertaken. The principal inquiries now in progress at the station have to do with the nutrition of plants, animals, and man, and with the bacteriology of the dairy.

We are proud of what the Storrs Station with its limited income has accomplished in the thirteen years of its existence. It has continually recognized a fact that is coming more and more to be understood by its friends in Connecticut, that, after all, the inquiry which on the surface appears to be the least practical, is actually the most useful. The station, therefore, is endeavoring to contribute its share toward the discovery of the laws which govern right practice in agriculture. Here will be the most lasting benefit to accrue from its work.

At the same time the direct application of the results of scientific research to farming is not forgotten. This is accomplished, in a large measure, by coöperative experiments with practical farmers. Experiments of this nature relating to the feeding of sheep and dairy cattle, the use of commercial fertilizers, and of leguminous crops for green manuring, supplemented by investigations in similar directions carried out at the station, have done much to improve the practice of farmers in the State along the line in which they have been conducted.

The investigations on dairy bacteriology have been an important factor in bringing about changes in the handling and care of milk and manufacture of dairy products that have resulted in raising the general grade of the products and giving them a more uniform quality.

The investigations on the food and nutrition of man are of particular importance to the farmer as a producer of food, 


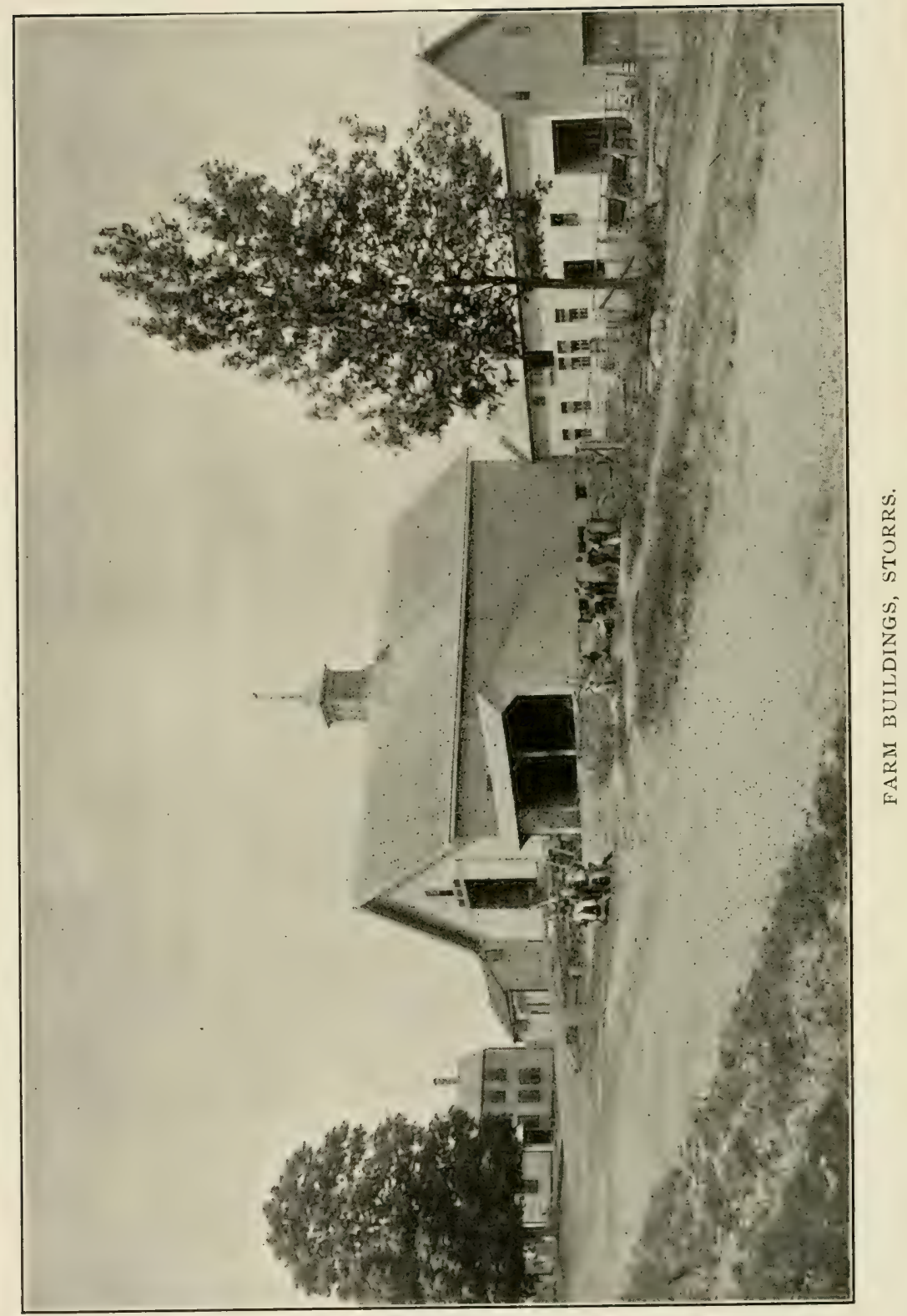


and to the farmer and all other classes of people as consumers of food. These have resulted in giving great aid to what is now a widespread movement for the betterment of public and private instruction regarding human physiology and hygiene, and for the application of the results of scientific research to the improvement of the dietaries of different classes of people. These results are being applied in the feeding of the army and navy, and in making up dietaries for public and private institutions where large numbers are fed. They are especially needed and useful for farmer's families.

The particular feature of these nutrition investigations that is of the widest scientific interest is the inquiry carried on with the Atwater-Rosa respiration calorimeter, an apparatus devised and elaborated at Wesleyan University in connection with the researches carried out in coöperation with the Storrs Station and the U. S. Department of Agriculture. Within this apparatus a man spends a number of days in active exercise or in complete rest, while the investigation is carried on in such a way as to show the demands of the body for nutriment under different conditions of work and rest, the duties performed by the different nutrients of food in supplying the needs of the body, and the nutritive values of food materials and the amount and proportions best adapted to the needs of people of different classes, with different occupations and in different conditions of life.

The value of this kind of research is not confined to the nutrition of man, but is useful also in the investigations of the economic feeding of domestic animals. An apparatus similar to the one in use at the Storrs Station, but large enough for experiments with oxen, is being built at the Experiment Station at the State College in Pennsylvania. In Europe, appropriations have also been made for similar apparatus for domestic animals at the Institutes of Animal Physiology at Bonn and at Budapest.

Our limited space will not allow a history of this movement, in which the Storrs Station has taken such an active 


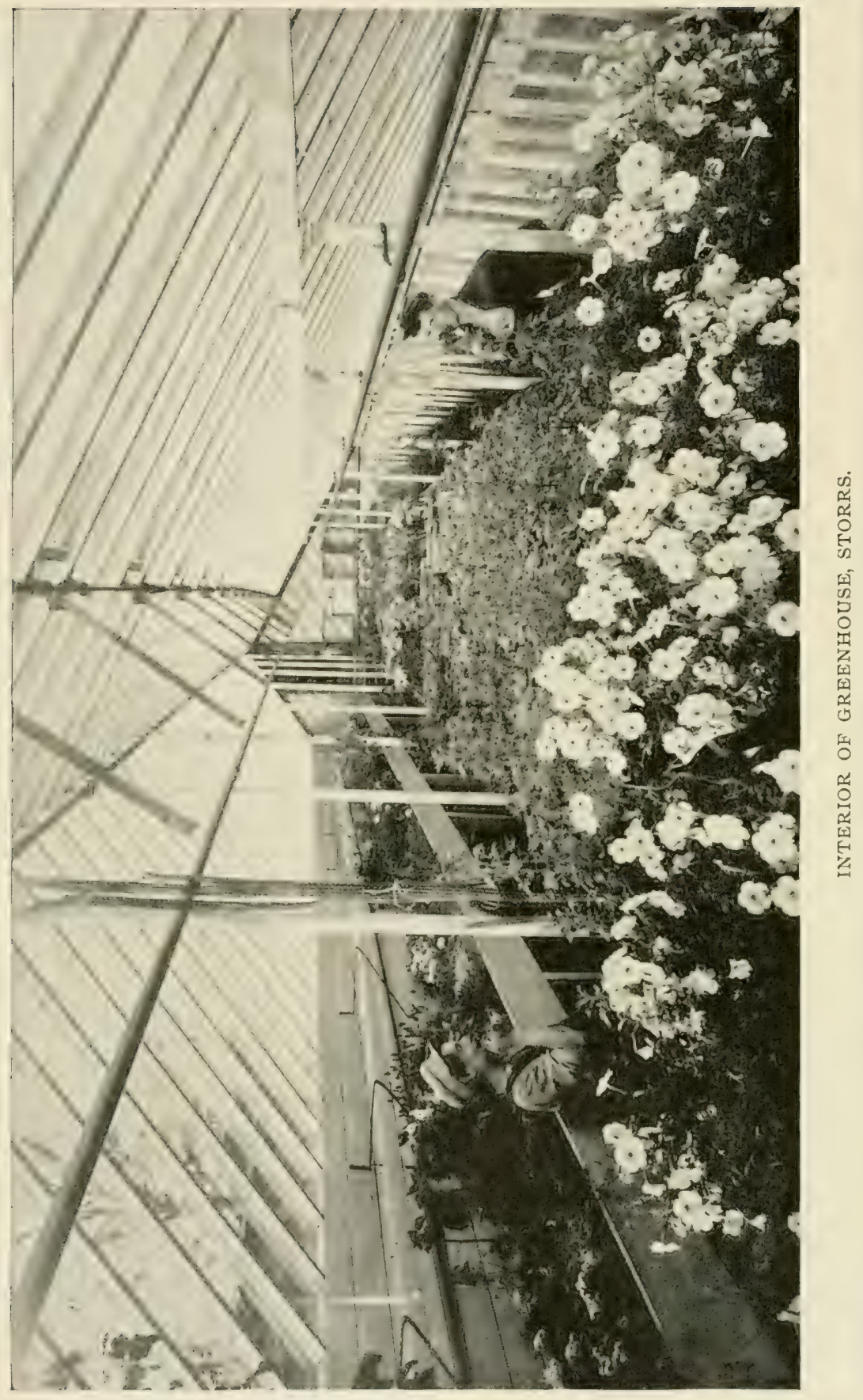


part, and which besides its scientific interest has also an immense practical value. Fuller details will be found in the Reports and Bulletins of the Station, and of the U. S. Department of Agriculture, with which it has coöperated.

Connecticut may well rejoice that she has been the pioneer in this country in the establishment of experiment stations. Perhaps no other expenditure of public money can compare with this in permanent and increasing material benefit. Connecticut is fortunate in having two first-class stations managed by men bound together not only by ties of friendship and a common interest, but also by legal provision in the organization of both stations, and with no rivalry except for the advancement of the common good.

\section{THE CAT'TLE INDUSTRY OF CONNECTICUT.}

Connecticut is noted for having developed some of the choicest cattle for beef, work, and dairy purposes of any of the States. According to the United States census of 1890 Connecticut has a larger percentage of pure bred cattle than any other State. Such breeds as the Devons and Shorthorns

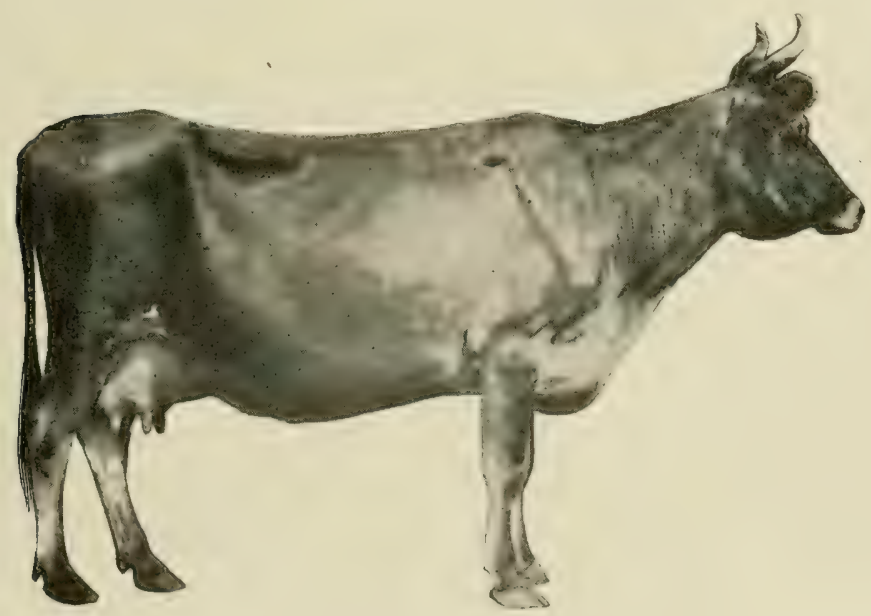

COPPER QUEEN, 58,659 (JERSEY).

Owned by Agricultural College. Record for one year 8,318 1bs. milk, 519 lbs. butter. 


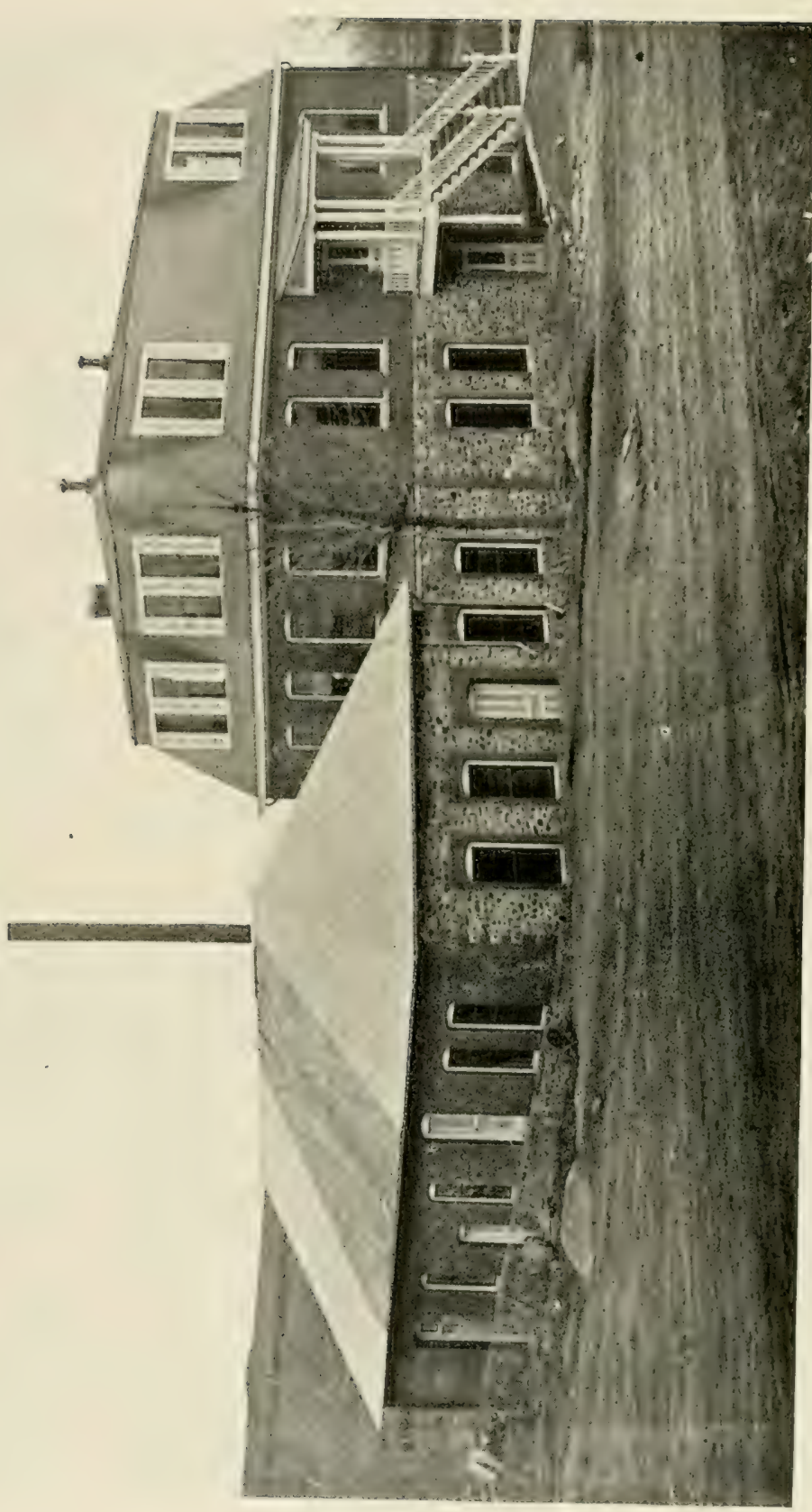


were prominent more than 60 years ago, and to-day choice herds of Jerseys, Guernseys, Ayrshires, and Holsteins are quite common. Town "strings" of cattle, many specimens of which were pure bred animals, were long a characteristic feature of all fairs. The rearing of cattle for work purposes was a profitable industry in the past century, and the fattening of beef was a leading branch of agriculture before the competition of the West crowded out the business. But the breed of cattle which has doubtless given Connecticut her greatest fame, is the Jersey. Many of the best herds in the

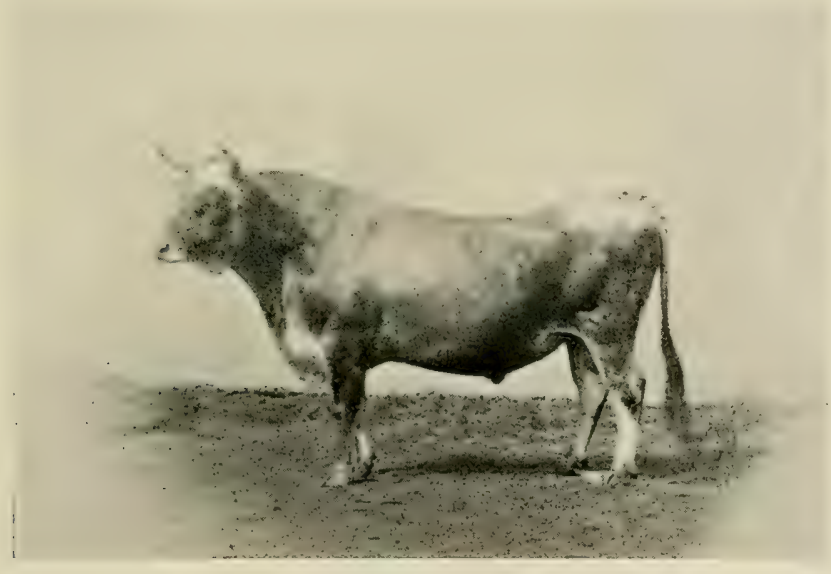

ALBERT, 44 (JERSEY).

Owned in 1867 by Silas W. Robbins, Wethersfield.

country trace back to animals of our earliest importations. The name which stands foremost among the earlier importers of Jersey cattle is that of John A. Taintor, of Hartford, who began his importations in $\mathrm{I} 85 \mathrm{I}$. During the next fifteen years such men as Colt, Beach, and Robbins may be named in connection with the importation of famous Jerseys. Greater care was doubtless exercised in the selection of this stock than in the choice of later imports after the "boom " in the breed began. Fancy points were wisely overlooked in the earlier selections, but merit in point of production was always demanded.

To-day Connecticut is preëminently a dairy state, ranking 
third among the states in the number of cows per square mile, and producing more than $10,000,000$ pounds of butter per year. The natural conditions which tend to place Connecticut in the foreground as a dairy state are her good grazing lands, a soil.well adapted to the growth of grasses and corn, and a generous supply of pure water. These natural advantages, together with the adoption of modern dairy and creamery appliances, are causing Connecticut dairy products to rank among the highest in the markets of the East.

Prof. C. S. Phelps,

Connecticut Agricultural College.

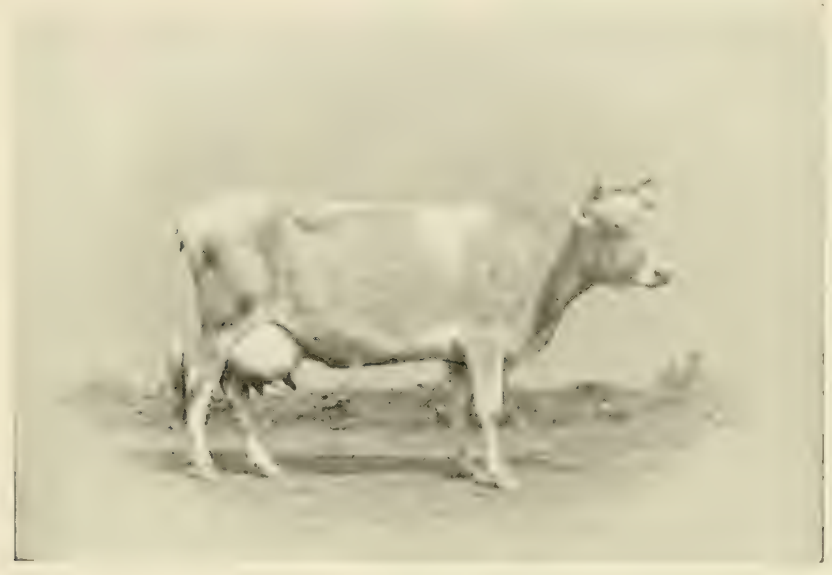

PANSY 6th, 38 (JERSEY).

Was owned in 1867 by Silas W. Robbins, Wethersfield.

Pansy 6th (38) was out of imported Pansy (8) and Albert (44); was sired by Imported Jerry (I5), and out of Frankie (I7), both first prize animals on Island of Jersey in I 864 . Pansy (8) was imported by John T. Norton in I855, and I bought her and all her calves but one, buying his whole herd to get Pansy 6th. Without any extra feed she gave in flush twenty-four quarts of milk per day. Jerry and Frankie were imported by W. B. Dinsmore in I 865. I am sure no better animals ever left the Island of Jersey than Pansy (8) and Frankie. The pictures are very fine likenesses. 
BREEDS OF CATTLE.

In the early part of the last century our cattle represented all colors, and claimed no particular breed; red, brindle, yellow, and black predominating, though "white face" and "line back" were in every herd. Every man preferred the color in which chance had marked his best cow. They were the result of early importations from England, before improved breeds were established, mingled with Dutch stock from York State. There were many good milkers, considering the conditions. They were expected to give milk in summer, and on the lush pasturage to lay in a store of fat for the cold and shortage of winter.

Some sections became locally famous for special varieties. The red cattle of Connecticut were early noted as working oxen. Devons led as the first thoroughbreds introduced, and the names of Hurlburt, Blakesley, Lindsley, Hyde, and Bill recall the beautiful, sprightly Devons; Sumner and Hitchcock, the stately Shorthorns ; Gaylord, the white-faced Hereford; Norton, Taintor, and Beach, the mild-eyed Guernsey; Pond and Wells, the spotted Ayrshires - motherly cows : Fish, the brown Swiss, majestic cows of a queenly type; while the breeders of Jerseys are too numerous even to select from the cow for the pet of the family, and the pride of the butter dairy, but still inheriting as much of the native wildness as any other breeds, and last, but not least, has also too many patrons to list, the Holstein - the largest milk producer of all, handsomely marked with black and white, and of royal aspect, which, once seen, no one will dispute her claim as a milker.

These are the foundation stock from which our cattle have been bred, each having qualities that give them preeminence for particular uses and conditions.

\section{RIDGESIDE FARM AYRSHIRES.}

The Ayrshire herd of S. M. Wells of Wethersfield, Conn., was established in I $864-65$ by selections from the herds of 
H. H. Peters and William Birnie of Massachusetts, and Walcott \& Campbell of New York.

In order to secure the best, from $\$ 400$ to $\$ 750$ each was paid for foundation stock.

Great care has been taken in selecting sires from cows representing the highest type of the breed. Of late years

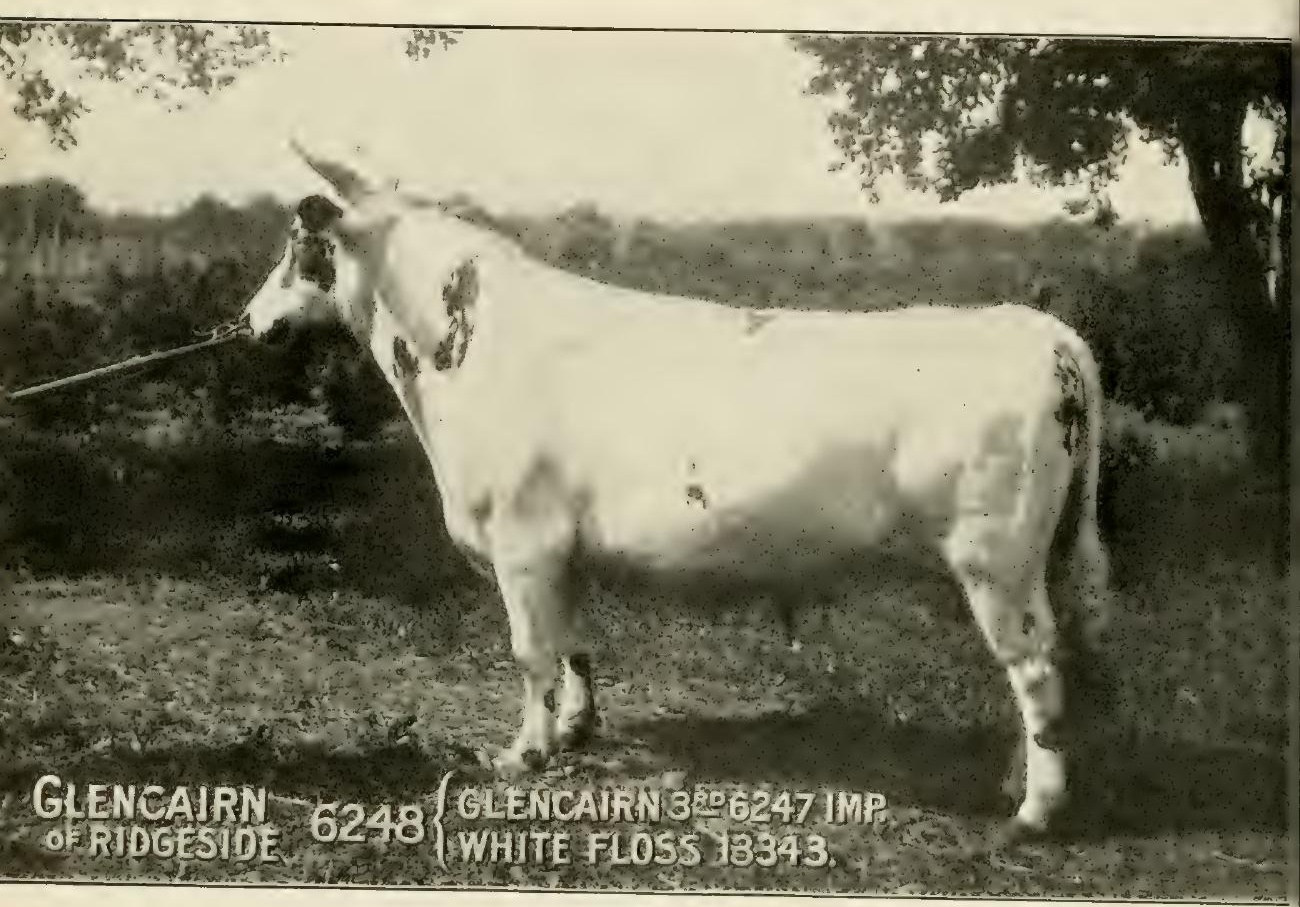

AYRSHIRE BULL.

Owned by S. M. Wells, Ridgeside Farm, Wethersfieid, Conn.

bulls for this purpose have been secured from leading herds in Canada.

The increase of this herd has been distributed from Maine to Mexico and nearly all the intermediate States, also consignments have been made to customers in Cuba and Japan, such notable cows as Mysie 2d, with a record of over twelve thousand pounds of milk per year for three successive years, and twenty-one pounds of butter in one week. Dolly $3 \mathrm{~d}$ 
gave ten thousand pounds a year for three successive years. Both bred in this herd.

The past season mature cows have given from seven thousand to eleven thousand five hundred pounds of milk; two-year-old heifers, with first calf, fifty-three hundred to seventy-four hundred and seventy-five pounds each.

This herd supplies the celebrated "Hygeia Milk," which sells in Hartford and vicinity for ten cents per quart.

The illustration shows the present head of the Ridgeside herd, Glencairn of Ridgeside, a grand individual of the choicest breeding. He is sired by the noted Glencairn 3d, imported and out of White Floss, she having won first prize in her class at the World's Fair, Chicago, and has received first honors at many of the leading exhibitions in the United States and Canada.

The young females in the herd plainly indicate that the present line of breeding will maintain the high character of this distinguished herd of Ayrshires.

BROIVN SWISS CATTLE.

Brown Saviss Cattle. - The size, large and substantial form, firm and elegantly proportioned, color shades from dark to light brown, light. shade of hair between the horns, on inside of ears, and a narrow line along the back. Horns rather short, waxy and black tips. Nose black, with mealy colored band around mouth. Black switch, hoofs, and tongue, straight hind legs, wide thighs, heavy quarters.

These cattle, first imported by Henry M. Clark, some years since, and a number of small bunches since by several parties. They cross well with other breeds, producing a very desirable grade of cattle, and as a rule taking strongly to the Swiss. Brown Swiss, hardy, active, gentle, docile, and kind. Large milkers, yielding rich milk, suitable for the manufacture of butter and cheese. Making large veal calves and meat of best quality, and producing the best of working oxen. The highest official world's record in a dairy test for a cow, 


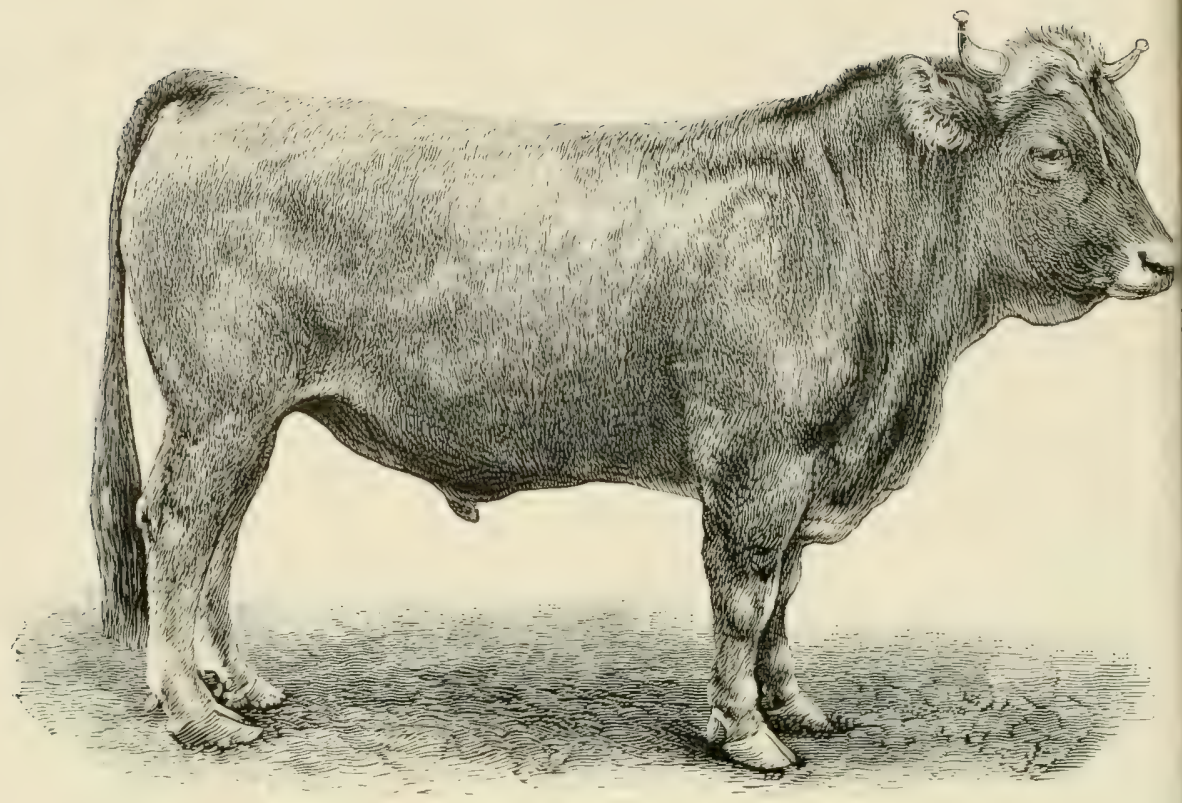

BROWN SWISS BULL.

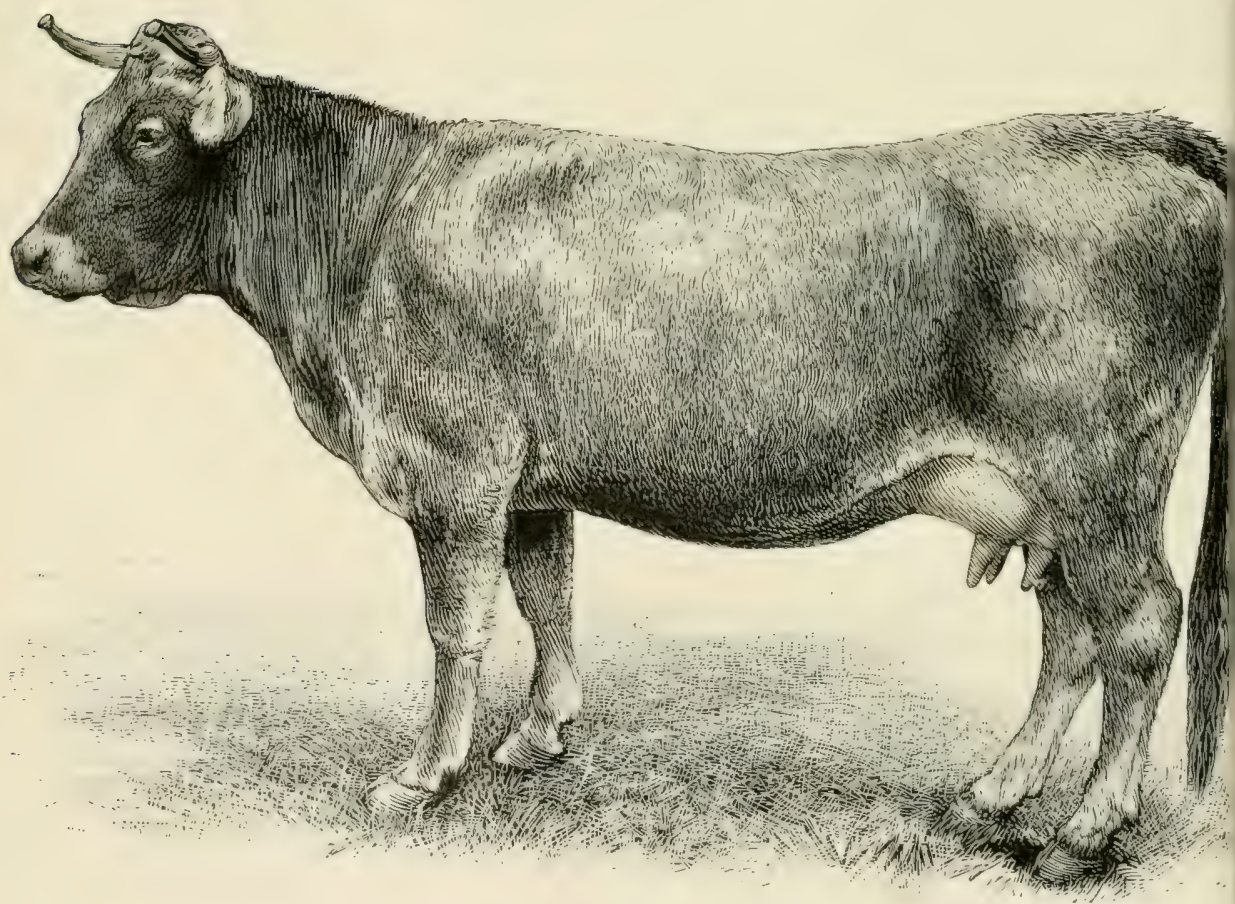

MIUOTTA (BROWN SIVISS).

Owned by N. S. Fish, Groton, Conn. 
away from home, is that of brown Swiss cow Brienze, No. I68, at Chicago, November, i S9I, taken by officials of Illinois University. The record as follows: Total for three days, 245 pounds milk; butter fat, 9.32 ; butter, 80 per cent. fat; pounds, I I.66. Average, 8 I.7 milk; 3. I butter fat; butter, 3.89 ; best day, 3.25 pounds butter fat, persistent milkers.

N. S. Fish, Groton,

Sec. and Treas. Swiss Cattle Breeders' Ass'n.

Weirvaloi Farm, Woodstock, Windham Co.

We have but little pure-bred stock of any kind in the county, - more on my farm, I judge, than any other three, as I have twenty-seven head of registered Jersey cattle. "Headlight Koffee" at the head of the herd, no bull of better pedigree in New England; forty-four head of pure Webb and Walsingham South Down sheep; two thoroughbred mares; four mares standard-bred on dam's side and thoroughbred on the sire's, and a pure-bred Cleveland bay stallion of imported stock, Vermont raising.

Very truly yours,

Geo. Austin Bowen.

\section{GUERNSEYS.}

The great and deserved popularity of Guernseys, won by their achievements in numerous dairies, show rings, and competitive tests with other breeds, is now so well established that this breed requires no further introduction to breeders and dairymen. The prominence they have attained arouses interest in the history of the first importation of Guernseys into Connecticut ; for, although they had been previously introduced and bred in Pennsylvania, Massachusetts, and New Jersey, the rapid growth and dissemination of the breed dates from this importation.

The Farmington creamery of Farmington, Conn., was founded in I870. Shortly after it began active operations, Mr. Edward Norton endeavored to arouse the patrons of this creamery to improve their stock. This led to the formation of a local club at Farmington. Numerous meetings were held 
to discuss the improvement of stock and allied interests affecting the success of the creamery. Mr. Norton advocated the introduction of Guernsey stock.

Mr. John T. Norton, the father of Edward Norton, had long been interested in Jersey and Alderney cattle, having made.several importations of these animals. Through the agency of Mr. John A. Taintor one of these importations included a cow possessing marked Guernsey characteristics, which tradition asserts to have been the best cow ever owned by John T. Norton. The presence of such a cow in these importations is not surprising. In fact, a strong suspicion prevailed with Mr. Norton and his friends that the early importations of Jerseys, which had been introduced as Alderneys, contained mixtures of Jersey and Guernsey blood. Some corroboration of this suspicion is suggested by many of the color descriptions of the early imported Jerseys, as recorded in Vol. I of the register of the A. J. C. C. It has even been stated that eleven of the twelve Alderneys (Jerseys) first imported by Mr. Taintor had white switches. Mr. Norton also felt that the larger frames and bodies of the Guernseys would commend them more to farmers than Jerseys, against which breed a great prejudice existed because of their size. At that time, when beef was an item of much more importance than now, this argument was correspondingly more impressive. Moreover, the richness in color and yield of milk and milk temperament were factors of no small importance. The causes thus stated, in connection with the fact that Mr. Norton had previously visited the Island of Guernsey, indicate, to a certain extent, why he espoused Guernseys. Mr. Norton's counsel finally prevailed, and certain members of the club subscribed a fund for the purchase of some animals.

Mr. Mason C. Weld was sent to the island to secure the animals. Fourteen females and one male were selected by him, which arrived in Farmington April is, I876. Upon their arrival the animals were led through the main street of 
$8 \%$

.

17ta:

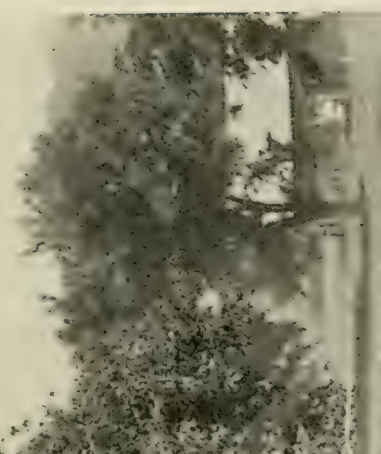

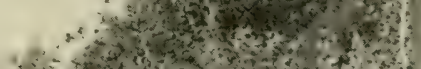

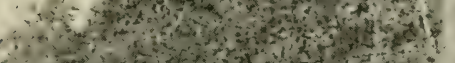

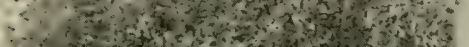

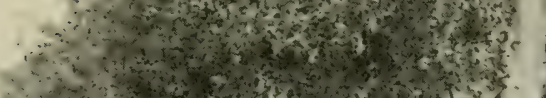
and

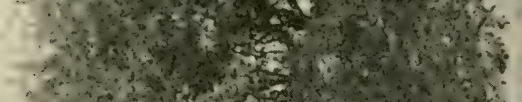

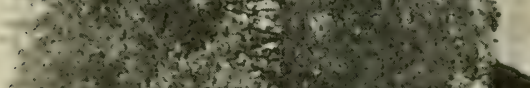
(2) (2)

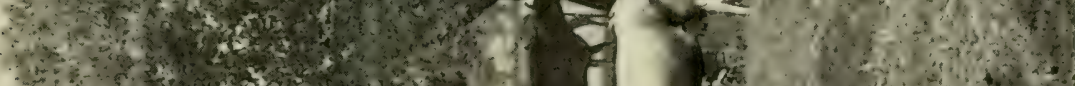

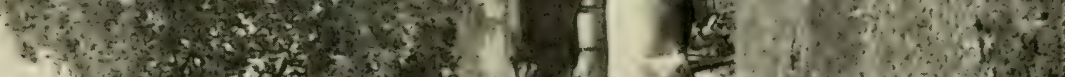

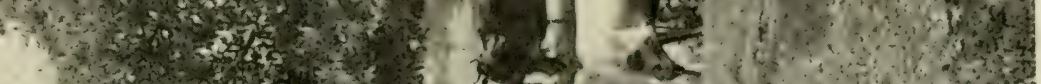

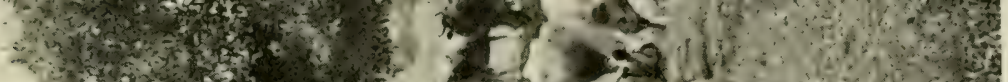
and of int

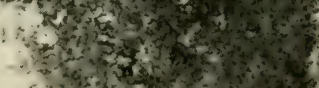
$(x)+2 x^{2}=0$

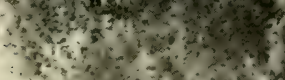

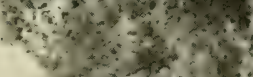

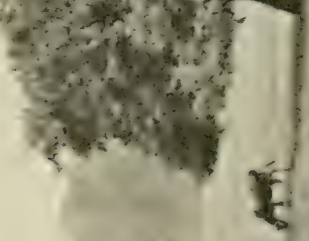

16)

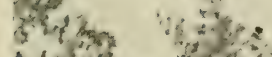

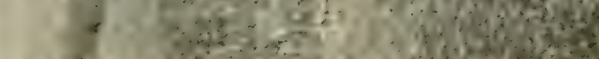

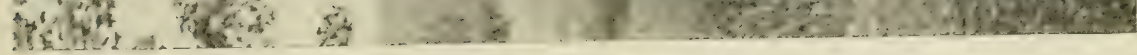


the town and created great interest and much enthusiasm. They were duly appraised and the choice of selection was auctioned to those who had subscribed to the purchase pool. That the competition was keen can be inferred from the fact that eighty dollars premium was paid for the first choice. The premiums obtained from the auction of choice was divided and distributed pro rata to the subscribers of the purchase fund. The animals were sold to the following people: Edward Norton, Augustus Ward, William M. Wadsworth, J. H. Andrews, Charles J. Thompson, Charles W. Lewis, E. W. Tillotson, George N. Whiting, Chauncy Deming, H. W. Barbour, and Miss Sarah Porter, all of Farmington, and Charles M. Beach of Hartford.

The interest and activity in Guernsey breeding received a tremendous impetus from this importation, which largely influenced the organization of the A. G. C. C., which occurred February 7, I 877 . The direct effect of this importation upon the organization of this club is perhaps best measured by the fact that in 1878 the club had a membership of thirty-seven, twelve of whom were residents of Connecticut; no other State had such a large representation.

Such, in brief, is the history of the first importation of Guernseys into Connecticut. No one can measure the vast benefits which have accrued to the dairy and breeding interests of our country from this well-conceived and successfullyconducted enterprise. It is rational to assume that such results were bound to come some time or other, but this does not detract in the least from the honor due those interested in this work. Led by Edward Norton, they conceived the thought, carefully weighed the chances, and having developed the courage of their convictions, resolutely proceeded to the execution of their plans. Let us ever honor and esteem these worthy patrons of agriculture.

Elmwood, Conn., May 24, 1901.

F. H. Stadtmuelier. 


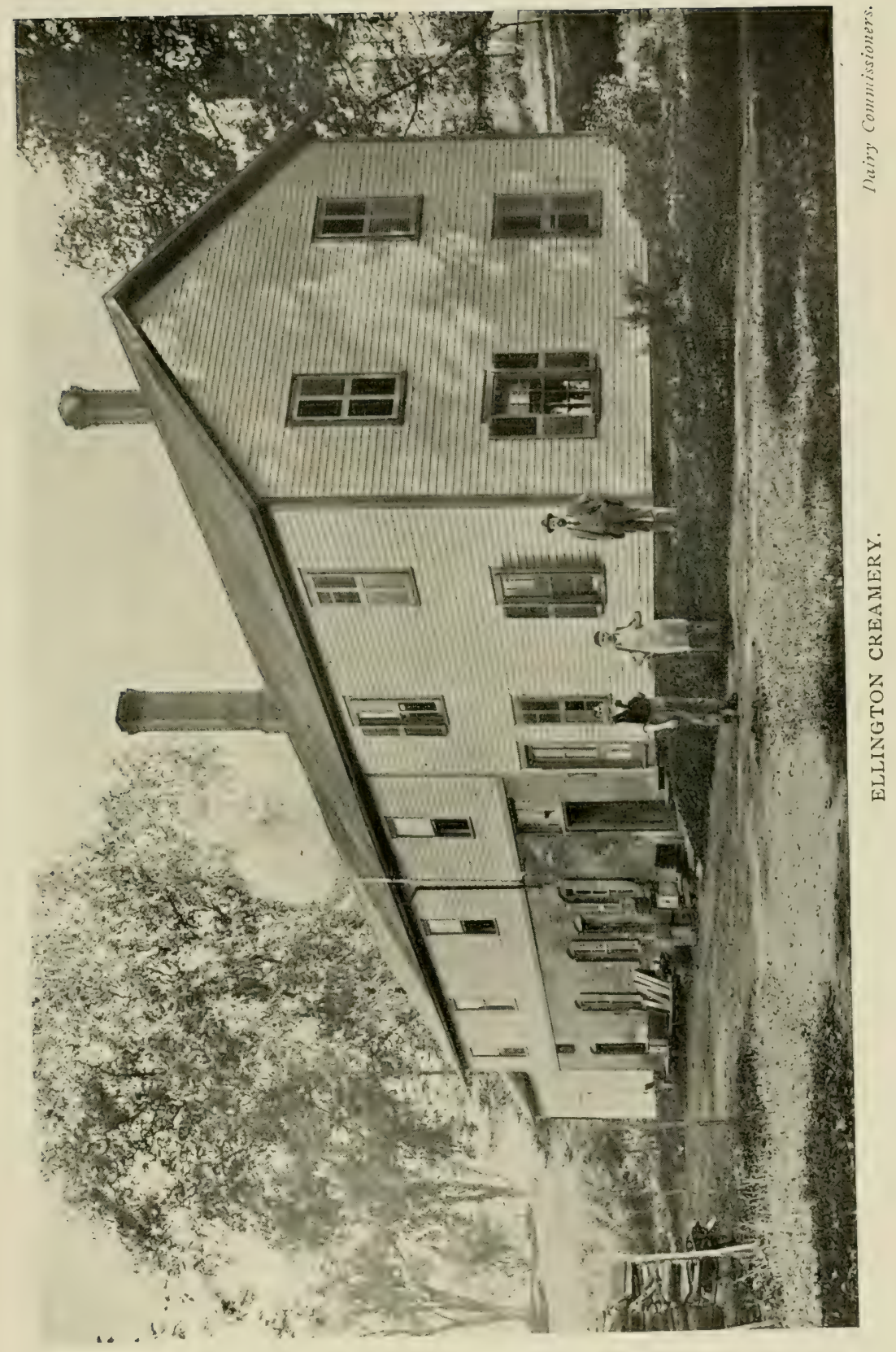




\section{DAIRY INTERESTS OF CONNECTICUT.}

J. B. Noble, Commissioner; R. O. Eaton, Deputy Commissioner.

Dairying in Connecticut at the present time is one of the most important branches of our agricultural interests. In the western part of the State large herds of cows are kept and the milk shipped to New York city. In the eastern part many of the farmers are sending milk to Providence and Boston. While the milk trade is an important part of our dairying, the butter business is, on many accounts, of still more importance. There are fifty-six creameries in the State doing a good business. Some of them are quite large. They are making a first-class grade of butter, which finds a good market at quite a remunerative price. Quite a large amount of butter is still made in private dairies and much of it is of extra good quality. In the last fifty years the number of cows in Connecticut has increased from eighty-five thousand four hundred and sixty-one to nearly one hundred and fifty thousand, with an average value, at the present time, of $\$ 34.80$ each. The increase in numbers does not represent nearly all the increase in the business, for better cows are now kept and more care and thought are given to breeding and feeding. The average milk production per cow has increased in the past forty years from two hundred and seventy gallons to four hundred and thirty gallons. The amount of butter made in the State has increased in the past fifty years from 6,498 , I 19 pounds to I I, 000,000 pounds. Dairymen in Connecticut are thoroughly alive to their business, intelligent and progressive men, and through their efforts much has been accomplished in bringing their business to a high and satisfactory standing.

CONNECTICUT DAIRYMEX'S ASSOCIATION.

This association was incorporated in 1889 for the purpose of helping the dairy and all of its related interests. The annual meeting is held the third week in January, at Hartford, where prominent dairymen from different parts of the country speak upon live questions connected with their business. 


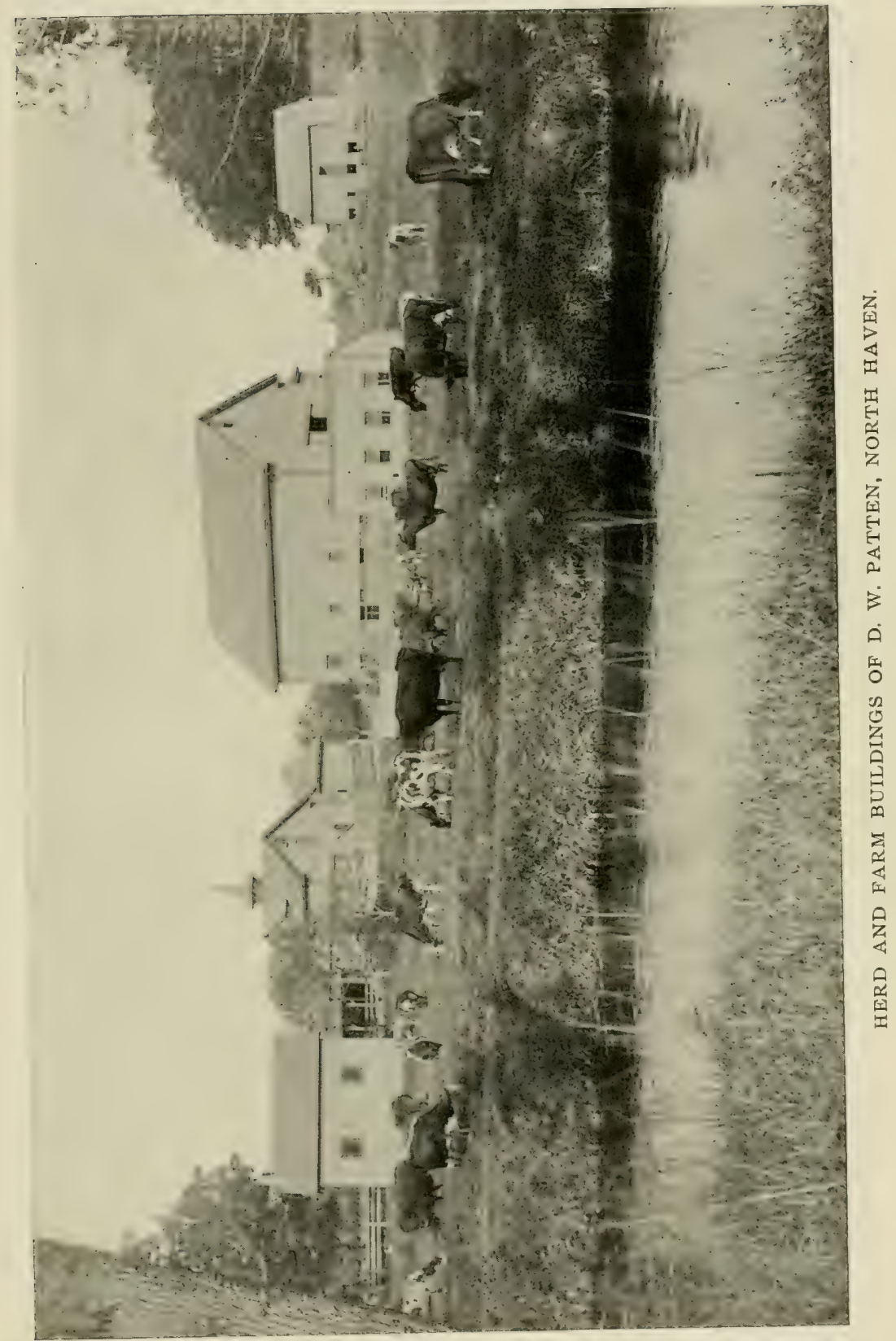


Officers of the association: Pres., H. F. Potter, Montowese; vice-pres., F. H. Stadtmueller, Elmwood; sec'y, George E. Manchester, East Winsted; treas., B. C. Patterson, Torrington.

The Connecticut Creamery Association has also been a prominent help to the dairy interests of the State. Officers: Pres., John Thompson, Ellington; vice-pres., Hiram Carter, Plainville; sec'y and treas., Frank Avery, Wapping.

The following figures show the business of a few of the large creameries of the State. Lebanon creamery received I,299,796 pounds of cream the past year and paid to its patrons $\$ 56$, I 16.65 ; Ellington, 775,62 I pounds of cream, paid to its patrons $\$ 34,328$. Wapping made, the last year, I93,778 pounds of butter, paid to its patrons \$42,994.99. Suffield, 626, I 28 pounds of cream received, paid to its patrons $\$ 27,5$ I 8.64 . Granby creamery paid to its patrons last year $\$ 39,000$. Canton paid to its patrons $\$ 23,799.80$.

The Jersey Cattle Breeders' Association has been an important factor in improving the dairy herds of Connecticut. Its membership is taken from prominent importers and breeders of fine stock, whose individual records have been high as milk and butter producers. S. C. Colt, president, Elmwood; R. A. Potter, secretary, Bristol ; B. W. Collins, treasurer, Meriden.

\section{DAIRIING IN CONNECTICUT.}

Vine Hill Farm Co.-C. M. Beach, Proprietor; C. E. Beach and F. H. Stadtmueller, Managers, Elmwood, Conn.

Dairying, although one of the oldest of all time-honored agricultural institutions of the State, has nevertheless experienced as great, if not greater, changes and improvements within the past two decades than any other agricultural industry. This progress was due to numerous factors, most of which, however, were merely incidental. Practically all the advance made was due to the following causes:

First. Improvement of stock.

Second. Co-operative dairying. 


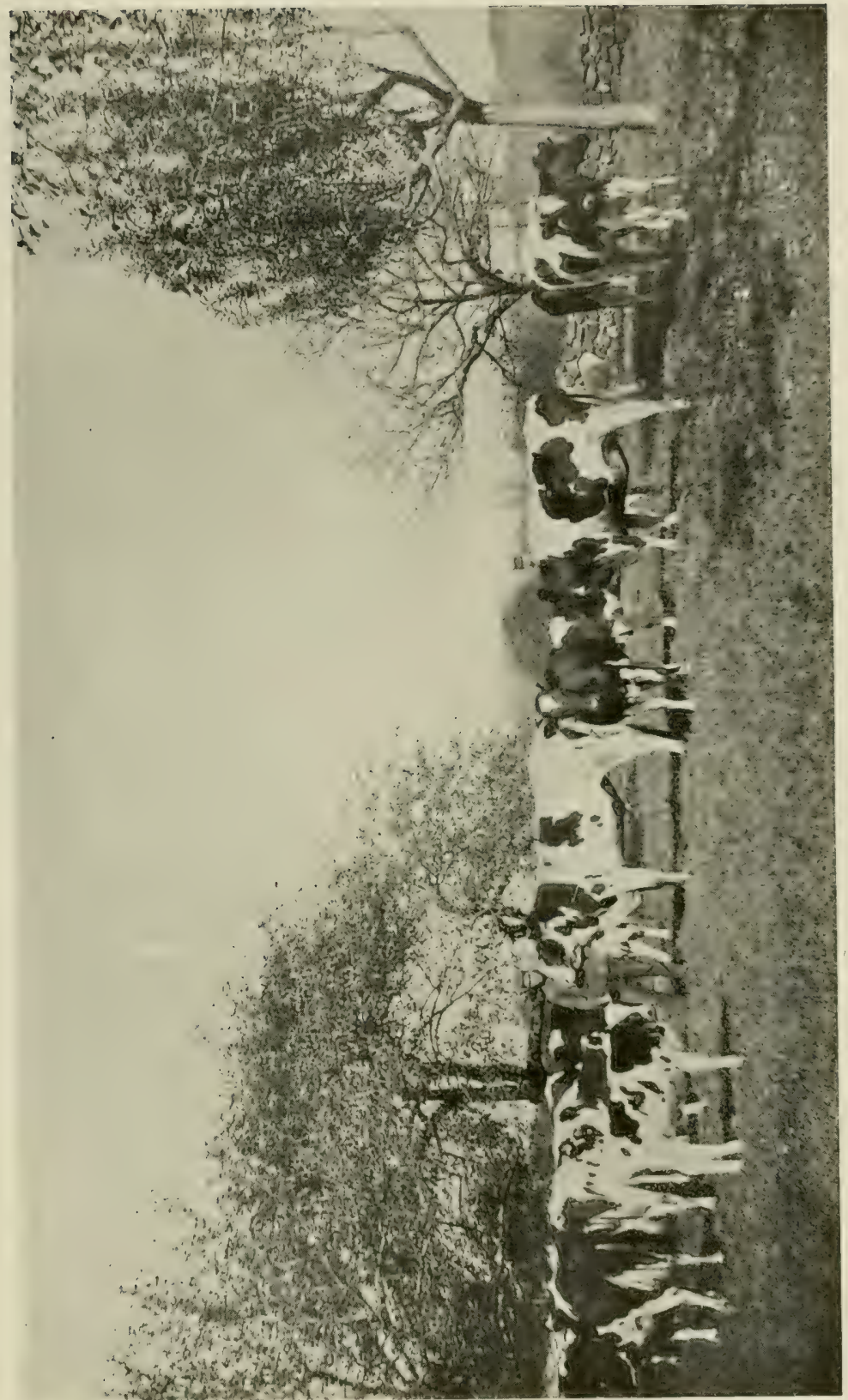




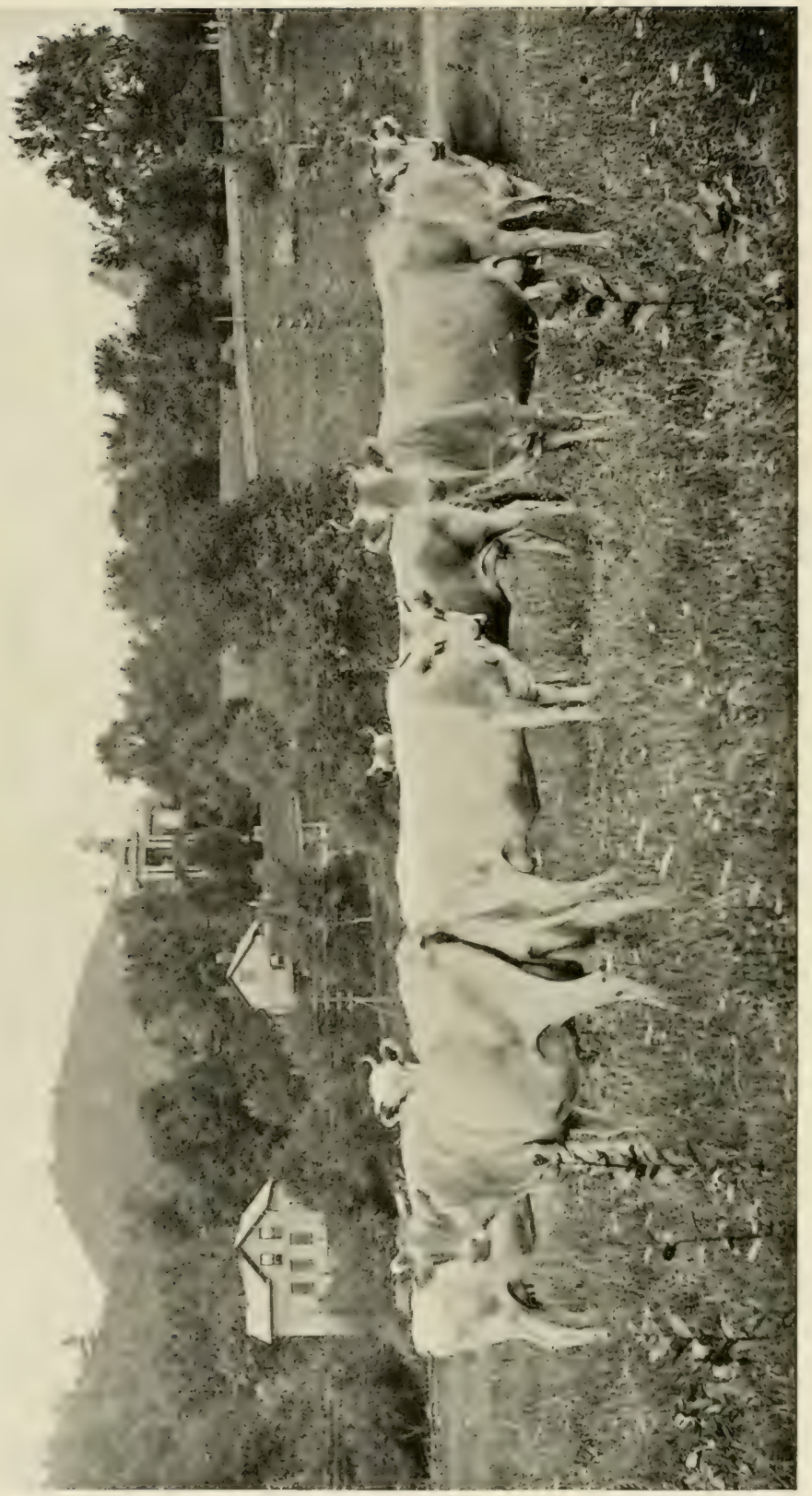

ن 
Third. Increase of population, which caused a transition from cheese and butter production to the sale of milk as a dietary.

The introduction of specific dairy animals was practically commenced in 1850 by the importation of Jerseys by Mr. John A. Taintor of Hartford. Mr. Taintor's efforts were soon followed by others, and in turn these importations were followed by the introduction of other notable dairy breeds, to wit, Holsteins, Ayrshires, and Guernseys. The superiority of these dairy animals so commended itself that within a few years the whole State became permeated with the blood of their descendants, and Connecticut soon became a veritable Mecca of breeding stock. This prestige has ever since been maintained, and much of the foundation stock of full-blooded herds of other States has been derived from the breeders of our State.

Associated or co-operative dairying was first attempted by Mr. Lewis M. Norton at Goshen, Conn., in about I.8Io. Subsequent events justified Mr. Norton's ideas, but co-operative dairying was not successfully established until the last third of the nineteenth century. Following then, as it did, the introduction of specific dairy animals, the conditions for successful co-operative dairying were more propitious. The quality of the butter was very much improved, as evidenced by the increased sale value of the product of all co-operative creameries.

The success of the pioneer associations gave a strong impetus to co-operative butter production, and creameries were rapidly erected, equipped, and put in active operation throughout the State. The zenith of this movement was attained at about 1890 , since when, owing to various causes, the most prominent of which will be discussed later, co-operative butter production has slightly declined. Numerous cooperative creameries are successfully operated to-day, while the competition resulting from them has stimulated private dairies to greater and better efforts. Despite this progress 


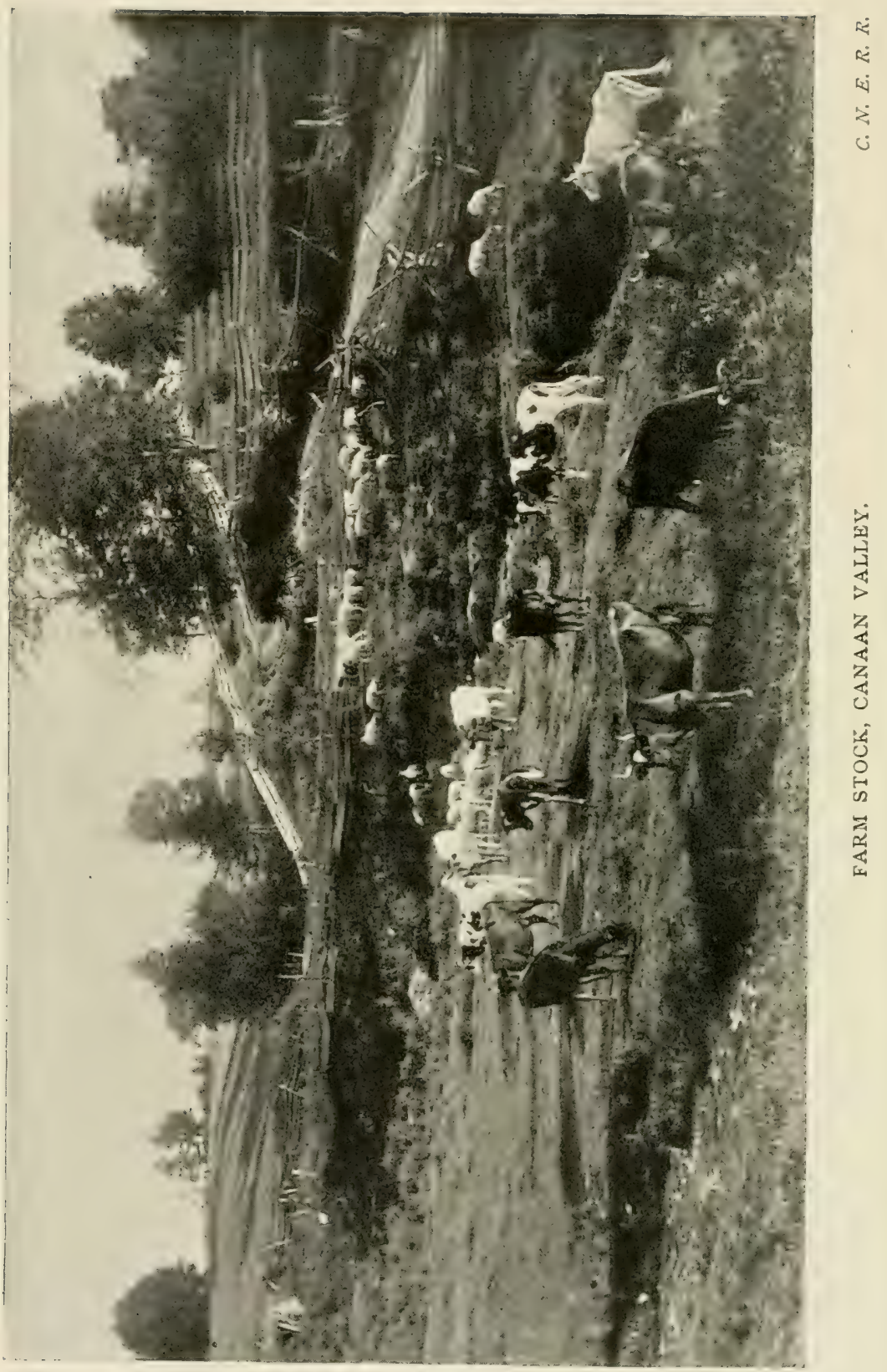


there is still ample opportunity within our borders for the successful operation of dairies devoted to the production of high-grade butter.

In the meantime the purely industrial and commercial population had rapidly increased, and milk contractors of New York, Boston, and Providence sought some of their milk supply in this State. As the demand for milk increased, the interest in butter production subsided. In the midst of this transition the well-known record of Connecticut men to be in advance is being well sustained. The deductions of bacteriologists are being introduced as rapidly as the consumers of milk will approve and support, and the output of hygienic and sanitary milk is rapidly becoming established.

In reference to the actual control of the hygienic quality of milk, credit must be accorded to a Connecticut dairy as occupying the most advanced position. The proprietor of one of our dairies conceived the benefits derivable from the daily bacteriological examination of milk produced to establish the care and efficiency of the labor bestowed in its production. For this purpose a bacteriological laboratory was equipped at the farm and has now been operated nearly two years for the daily examination of milk.

Our knowledge has been deficient regarding the relation of milk to the public health, but at the dawn of the twentieth century we are emerging from some of the fallacious traditions which have attended milk production, and are just entering an era of greater possibilities and activities than was ever accorded our progenitors. 


\section{OFFICIAL DIRECTORY OF THE CONNECTICUT PATRONS OF HUSBANDRY, FOR 1901.}

OFFICERS OF CONNECTICUT STA'TE GRANGE.

Master, B. C. Patterson, Torrington.

Overseer, Iverson C. Fanton, Westport.

Lecturer, Frank S. Hopson, Station 3, Bridgeport.

Steward, J. B. Bliven; North Franklin.

Asst. Steward, Robert W. Andrews, New Britain.

Chaplain, Rev. C. H. Smith, Plymouth.

Treasurer, Norman S. Platt, New Haven.

Secretary, Henry E. Loomis, Glastonbury.

Gate-Keeper, E. H. Wright, Clinton.

Ceres, Miss Gertrude U. Bradley, Waterbury.

Pomona, Mrs. Sabra M. Kelsey, Higganum.

Flora, Mrs. Maude K. Wheeler, Storrs.

Lady Steward, Mrs. Alice L. Potter, North Woodstock.

\section{Executive Committee.}

Orson S. Wood, Ellington,

J. H. HALE, South Glastonbury,

H. F. Potter, New Haven,

B. C. Patterson, ex officio,

H. E. Looms, ex officio,

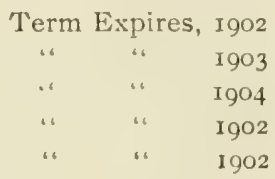

Finance Commitee.

H. C. Dunham, Middletown.

R. R. Wolcotr, Wethersfield.

George A. Hopson, East Wallingford.

The evolution of Connecticut agriculture during the first half of the last century was at a limping gait, but with the outbreak of the Civil War it progressed with rapid strides. Necessity, the most poteritial of all the influences that impel men and nations forward in the march from the old to the new, gave to agriculture an impetus whose force is still unspent.

Invention saw the fields waiting to be sown, and the harvests ungathered, and gave us substitutes for able-bodied men in the form of farm machinery. Science, too, lent her aid, and by her development of new and more simple methods of culture, the agriculture of to-day has transferred-its allegiance from muscle to brain.

In such a tumult of change, such a casting off of theories and methods, such an upheaval of long-laid foundations, 
there is need of conservatism to steady the movement, and, fortunately, this element is not wanting.

Agricultural education, now so generally diffused, is helping greatly to lift the burdens of former years, and to make the farm home attractive. New industries have crowded out the old, and our young men are beginning to realize the possibilities of agriculture in Connecticut under the new régime. The allurements of the city are losing their fascination, and the professions are crowded to nearly their limit. Such a combination of influences are gradually working out the problems of production and profit, and the new century is full of promise for the Connecticut farmer.

The methods of the past demanding the severest and most constant toil are left behind, but they dictated and fostered a social, civil, and religious sturdiness of character that has made Connecticut the synonym of integrity, intelligence, and progress, and is to-day her guarantee of future prosperity. The depression of agriculture during the last few decades has dotted some sections of Connecticut with abandoned farms, greatly increased our forest area, and is chiefly responsible for the exodus of young men and young women from the home farm to some land of promise. The work of subjugation must be renewed. These old hills must be brought back to cultivation and made again to teem with flocks and herds. This is our necessity, and therefore it is not prophecy. The farmer of the future, equipped with the appliances evolved by necessity, aided by invention, approved by science, and with the stimulus of an intelligent and steady purpose and a love for his profession, will surely be found fully equal to his task.

\section{Prof. L. P. Chamberlain,}

Connecticut Agricultural College.

CONNECTICLT POMOLOGICAL NOCIFTY.

N. S. Platt, President, New Haven; H. C. C. Miles, Secretary, Milford; Roswell A. Moore, Treasurer, Kensington.

CONNECTICUT HORTICULTURAL SOCIETY.

A. C. Sternberg, President, West Hartford; L. H. Mead, Secretary, Keney Park Nursery, Hartford; W. W. Hunt, Treasurer, Hartford. 


\section{FRUIT GROWING IN CONNECTICUT.}

The tender stone-fruits have been grown more or less in the State for a long time, but only in a small way. About 12 years ago a few growers began to give special attention to peaches for market. They were successful. They organized a society for mutual benefit. This soon grew into the present very active and prominent State Pomological Society. This association has disseminated much valuable information. The result has been to develop the peach business into a very important industry. The Japan plum has also at the same time become one of the very important fruit crops of the state. These two fruits to-day occupy thousands of acres which, I 5 years ago, were used for pasture or ordinary farm crops. Planting of both classes is still extensively done each year, the growers supplying the home market and reaching out for those still larger which are within easy shipping distance.

With all small fruits the State is nearly fully supplied by growers living in each section where the fruit is marketed.

Apples have always been largely grown, but with the general decay in other agricultural branches the apple orchard was also neglected, and as a natural result returned but little profit. The nearness to large markets and the profits in other fruits has again brought apple growing into notice. Old orchards are being renovated and cultivated, or are removed and new ones planted and attended according to the latest ideas of successful growers. Much land otherwise of little value is being devoted to this crop. Much more yet can be profitably employed in the same way. To aid in developing apple growing, the State Agricultural College has planted quite an extensive orchard of trial varieties, which is just coming into bearing. Last year it also planted a ten-acre orchard for commercial purposes, with the idea of determining the cost and best methods of treatment. Several plans of inter-planting and filling are being tried, as well as the methods of cultivation now deemed to be the best. It will be a valuable object-lesson in the near future. 
The fruit-growers of the State have discovered that they are near the most valuable markets for their products in the United States; also that the soil and climate are adapted to growing the finer varieties; that it only needs attention to business to produce those that bring the highest price when marketed, and that there is ready sale for all that can be grown.

\section{A. G. Gulley,}

Professor of Horticulture, Conn. Agricultural College.

\section{PEACHES.}

Commercial peach culture in Connecticut, although a comparatively new industry, is now a leading feature of our agriculture.

From the earliest settlement, peaches have always been grown for home supply; the first commercial orchard of any size was started in about 1875 , more extensive orchards were planted in the early eighties, and the first heavy impress on the markets with Connecticut peaches was made in 1887 and i889. Large size, great beauty, and fine flavor opened the way for ready sale at high prices. Thousands of trees were planted in the next few years, so that by 1896 there were one million five hundred thousand trees in the orchards of Connecticut, and'now, five years later, there are over three millions.

Hartford, New Haven, Middlesex, and Fairfield counties have the most trees in the order named, while Tolland, New London, Windham, and Litchfield follow with a less number. While a few townships in the State have but little land suitable for peaches, in nearly every township there are many hundreds of acres suitable to profitable peach culture.

The earliest large plantings were mostly on elevated fields that had been used for mowing or tillage, but at this time, for the sake of elevation and suitable frost and air drainage, many acres of so-called abandoned farm lands on hillsides and hilltops are being cleared of brush and timber and planted to peaches; lands that can be bought at from $\$$ IO to $\$ 20$ per 


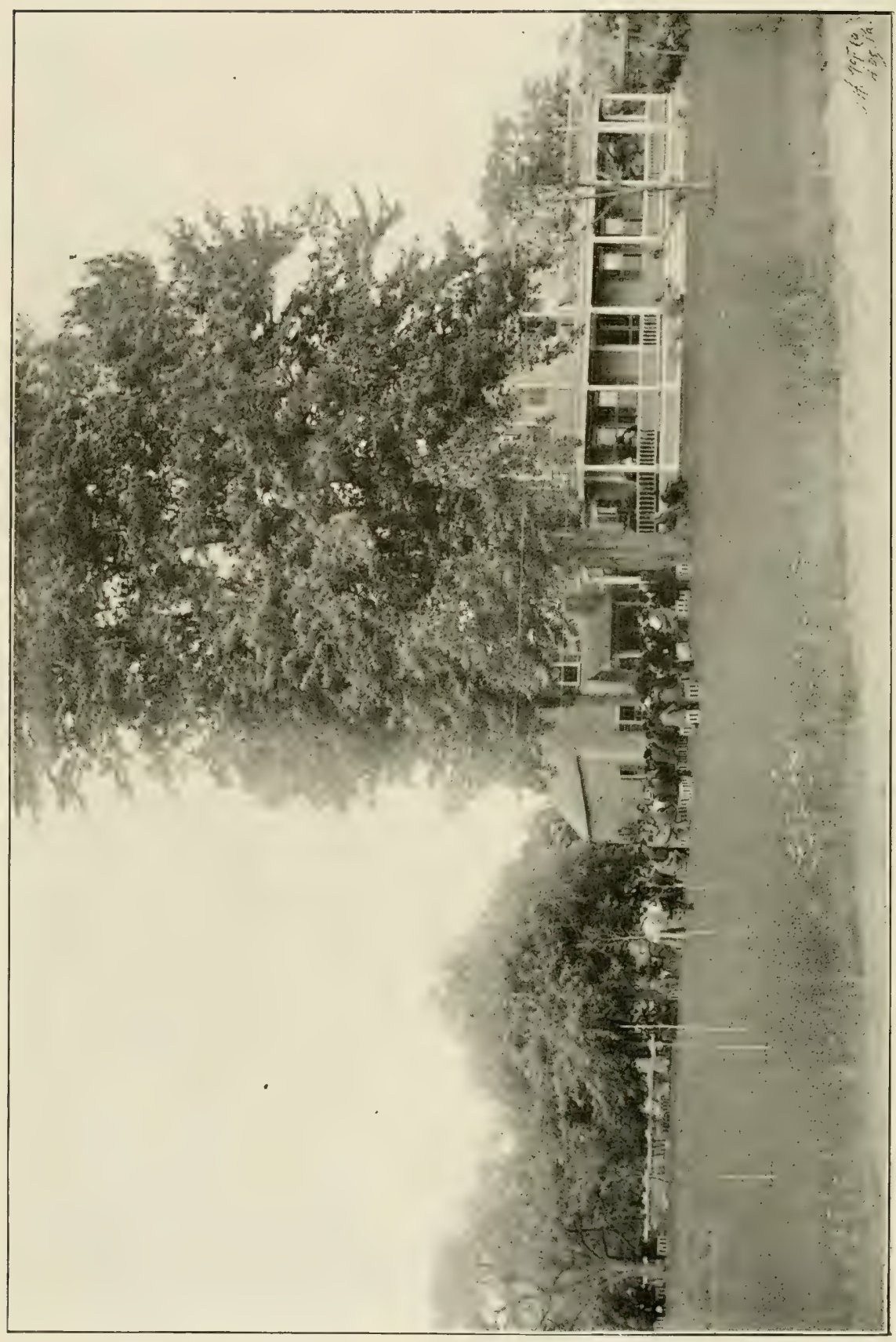


acre, when cleared and planted in peaches, in four or five years return profits of $\$ 200$ to $\$ 300$ per acre, and often twice as much. In the earlier plantings, medium to later varieties, such as Oldmixon, Late Crawford, Stump, etc., were planted so as to supply the markets after Delaware and New Jersey peaches were out of the way, but experience has shown that no matter what the season, Connecticut-grown peaches, by their superb size, beauty, and flavor, will drive all others out

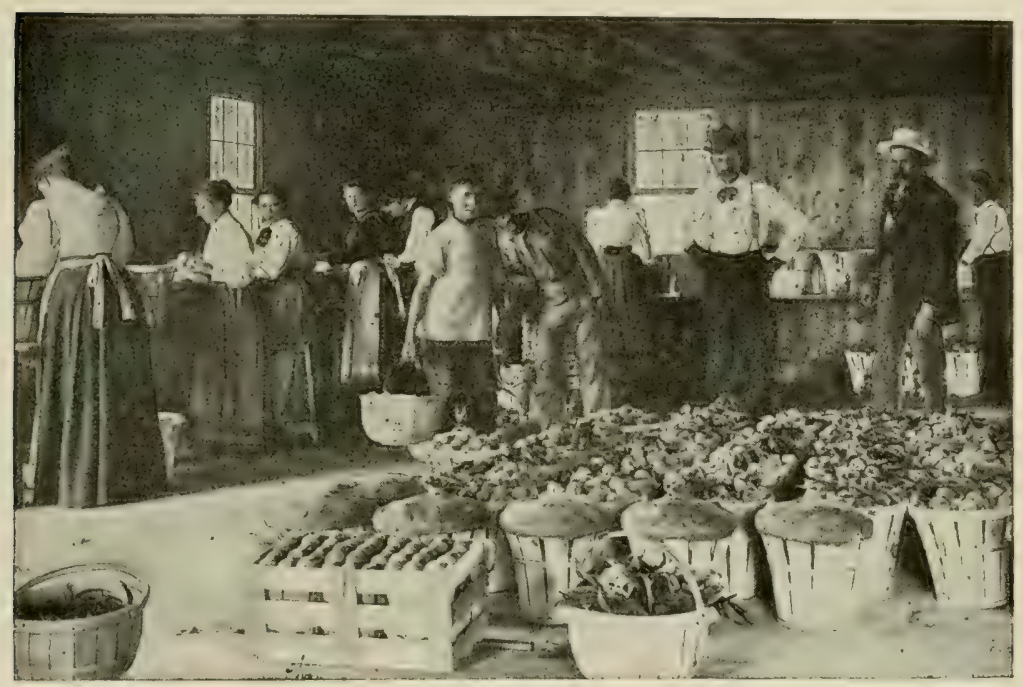

PEACH PACKING. J. H. HALE.

of New England markets. So that, in recent years, early and medium varieties are being planted, and the fruiting season is now from July I 5 th to October Ioth. Most orchardists practice thinning the fruit, so that the trees are never allowed to overload. Marketing is mostly in I6-quart Jersey baskets, and from the present outlook the I90 I crop of Connecticut peaches will be upwards of three million baskets, worth at least $\$ 2,000,000$ in the orchards. Careful investigation shows that for surety of crop, Connecticut is as reliable a peachgrowing State as any in the Union. In the last twenty years it has had ten full crops of fruit, three fairly good ones, three partial ones, and four almost total failures. One of the fail- 
ures was caused by a frost in May, when the trees were in bloom; one by two weeks of warm, rainy weather at blooming time, and all others by extremes of frost, from I 2 to 22 below zero, that killed the dormant buds in winter. Six years out of eight the freezing was done between December $22 \mathrm{~d}$ and January $2 \mathrm{~d}$; once it was done late in January and once again late in February. The older so-called peach-growing States cannot show as good a record as this.

J. H. HALE, South Glastonbury.

Mr. Hale, the pioneer in peach culture, fears no competition. When Connecticut is supplied, other markets are ready for our surplus. His Georgia peach orchard only prepares the way for the sale of the Connecticut crop, and he welcomes every effort to extend this industry.

GRAPE CULTURE.

The beginning of my grape culture was in ${ }_{1} 8_{5} 6$. Situation for vines was on the southern slope of Mt. Carmel, near the base, where the soil is largely composed of the disintegrated trap-rock which protrudes through the layers of the sandstone underlying the lower section of this locality. The varieties then known for culture were Isabella and Catawba. About ten years later the Concord and Clinton were planted in 1864 . Being then a novice in grape culture, and wishing to give the experiment the best possible care, I employed a German vine-dresser and gave the care of the vineyard to him. The success in growing grapes was phenomenal, and proved beyond controversy that Connecticut is the home of the grape.

My vineyards, cared for and planted by the old German vine-dresser, who had been a soldier in many wars, are still productive. They have endured the scourge of the black rot which has devastated so many vineyards, and though not always escaping, have recovered from its ravages, and vines are still fruitful at an age of nearly forty years. 


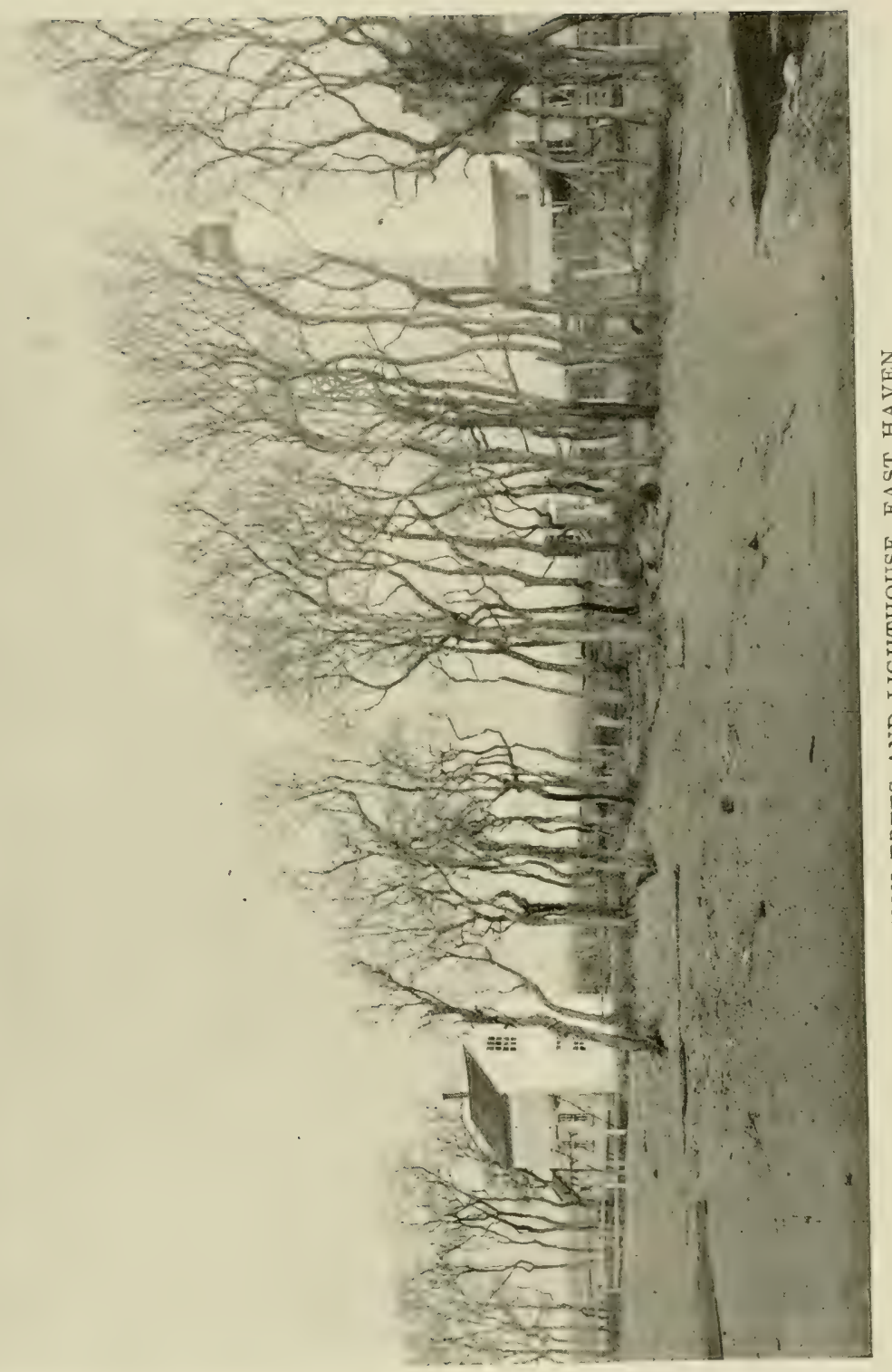

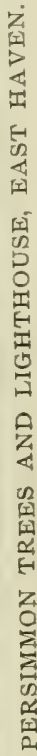


The vines planted by cuttings, without removal, in the sandstone rock broken up to a depth of two feet, are, as the old vine-dresser predicted at the planting, now the most productive. Later, in I890, I caused a new vineyard to be planted wholly by cuttings of the Concord, without fertilization, which have produced full crops of grapes during the past few years, and have been entirely free from rot, without having made use of any preventive on this special vineyard. At the planting the soil was worked, and continued to be for a few successive years. Later, as a test to avoid rot and lessen the growth of the vine, no culture has been given. The annual pruning is all the outlay. The yield has been sufficiently large to insure success, and proves our soil and climate is the home of the grape. If a forced large growth induces disease, curtailment of production may be the best remedy.

The Green Mountain grape has also endured this severe test with perfect success, and fully ripened on full-bearing vines in a grass sod. My tribute of praise is due the Green Mountain grape as the best out-of-door grape in cultivation for a table grape, taking into account its early ripening and sweet flavor without any of the unpleasant after-taste caused by a surfeit.

The wine-making qualities of the Concord and Clinton grapes, when mixed in the fermenting tanks, are of sufficient sweetness without sugar.

Very truly yours,

J. H. Dickerman.

Apples are grown successfully all over the State. The strong soil of the hills is best adapted for winter fruit in color, flavor, and long-keeping.

Peaches, which had become almost extinct from the yellows, restored by the skill of a few cultivators, find a congenial location on the hills in the less elevated parts of the State. The quality of Connecticut peaches is unsurpassed, and the market is the best, for we are near the northern limit of suc- 


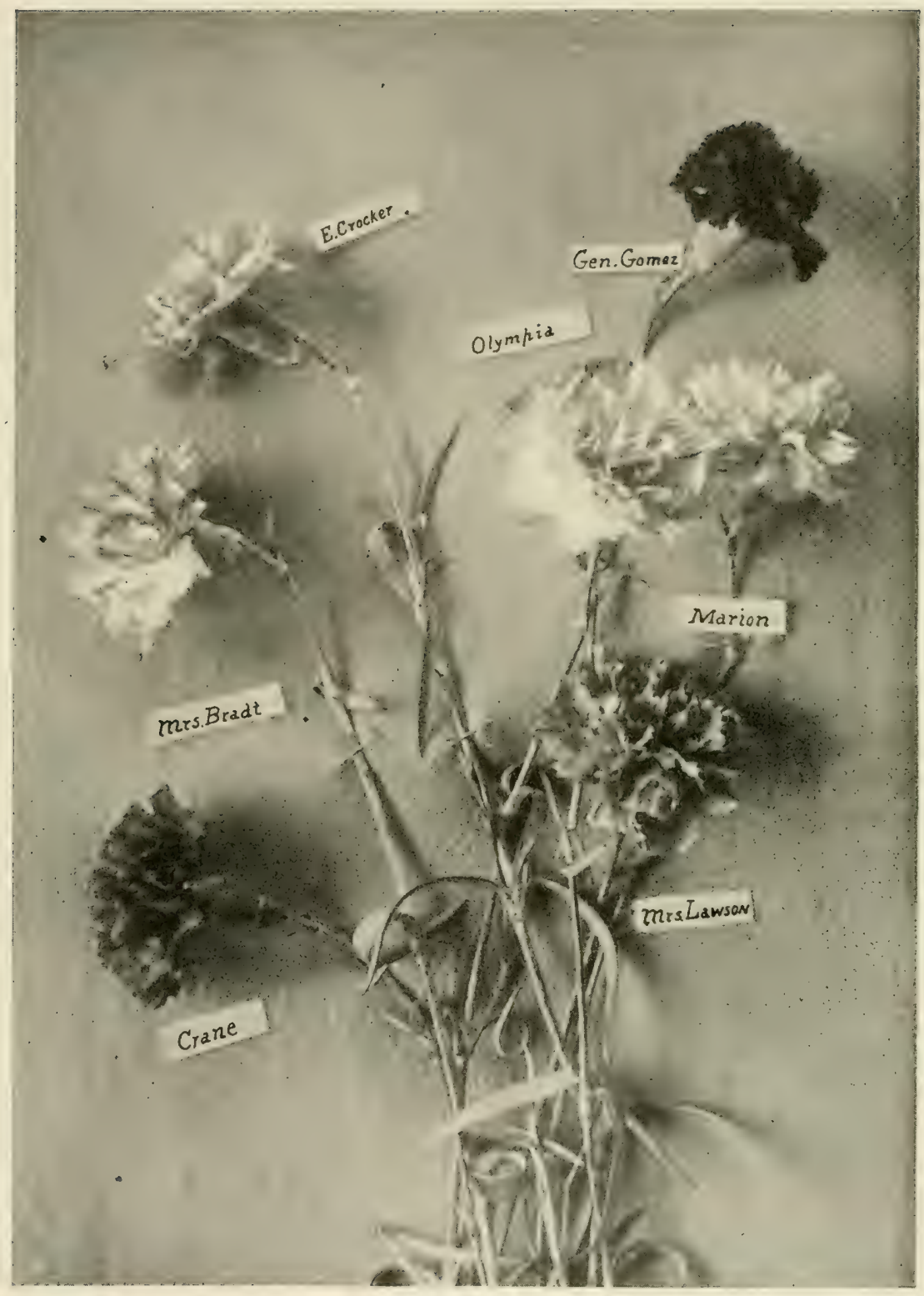

CARNATIONS.

Raised by Arthur Brandegee, Berlin. 
cay of moral worth, while the culture of natural beauty is a sure demonstration of progress in all good and worthy life.

The love and culture of flowers is the most natural of all our asthetic tastes; it enlarges the life by bringing it into sympathy with and knowledge of the laws that govern our proper development. No man or woman can properly care for a garden of flowers without learning much more than the way flowers grow ; they acquire also the secret of self-culture, and so are brought into harmony with the essential laws upon which all progress depends. To comprehend the methods of Nature in any department of her work is to understand the principles upon which all her efforts are made.

The last decade has shown wonderful advance upon all others in the florist's art in the State of Connecticut. Unfortunately, no full statistics are available, but the amount of glass devoted to the culture of flowers has doubled, at the very least, the most recent figures showing about eight hundred thousand square feet given entirely to commercial purposes, and at this date there are at least one million, for every year an ever-increasing amount is built. No other business can show equal development, and when to this is added the many costly and beautiful private greenhouses that are found in every city, the enormous strides made in the State are apparent to all.

The effect of this advance in the culture of beauty is everywhere apparent, and seen in two results: the increased value of property and the more attractive appearance of every town, village, and city in the State. Some of our villages and small towns are like parks or large gardens; there is universal striving on the part of the people to adorn the grounds under their control with all possible beauty, and the old-time neglected, weedy dooryard that was an eyesore to the passer-by is seldom to be found. The people have discovered that no embellishment is so cheap or so effective as a garden rich with all the charms collected from the best flora of the earth, and brought within their reach by the skill and 
enterprise of the professional florist; and while the rich may have their jewels and picture galleries, the poor have equal loveliness within their reach through the modern development of the florist's art.

And it is no disparagement to the professional florist to say that some of the most beautiful flowers are grown by the amateur. Nature is ready with her kind responses to all who take the trouble to seek her treasures, and many who grow flowers in the State solely for the joy they find in the recreation, accomplish as much in the revelation of beauty as those who give their lives to the work.

It would be invidious to name but a few of the many suc. cessful florists, and impossible to name them all, but one may be mentioned who has, by great skill and industry, created the largest plant in New England-Mr. Pierson of Cromwell; any visitor will be more than repaid by a visit to his wholesale establishment, and see there how flowers are grown and packed for distribution to every part of the country, while on the other hand, the carnations pictured in this book were grown in a small house, and yet can vie with any raised anywhere. They were grown by Mr. Arthur Brandegee of Berlin, who grows flowers only because he loves them, and are not surpassed in beauty by the product of any professional florist.

To give some idea of the enormous magnitude of the business done by A. N. Pierson it may be stated that in the year I900, of the staple flowers - roses, carnations, bunches of lily of the valley, and violets - the sales reached about three millions. Of roses alone there were I, I 54,O I 2 , and the cash returns exceeded $\$ 120,000$. There are an average number of one hundred and twenty-five men employed, and the amount paid for labor was about $\$ 56,000$. The establishment is the main stay of Cromwell, and the generosity and good citizenship of Mr. Pierson is felt throughout the town, while the rapidity of the growth of the business proves not only 


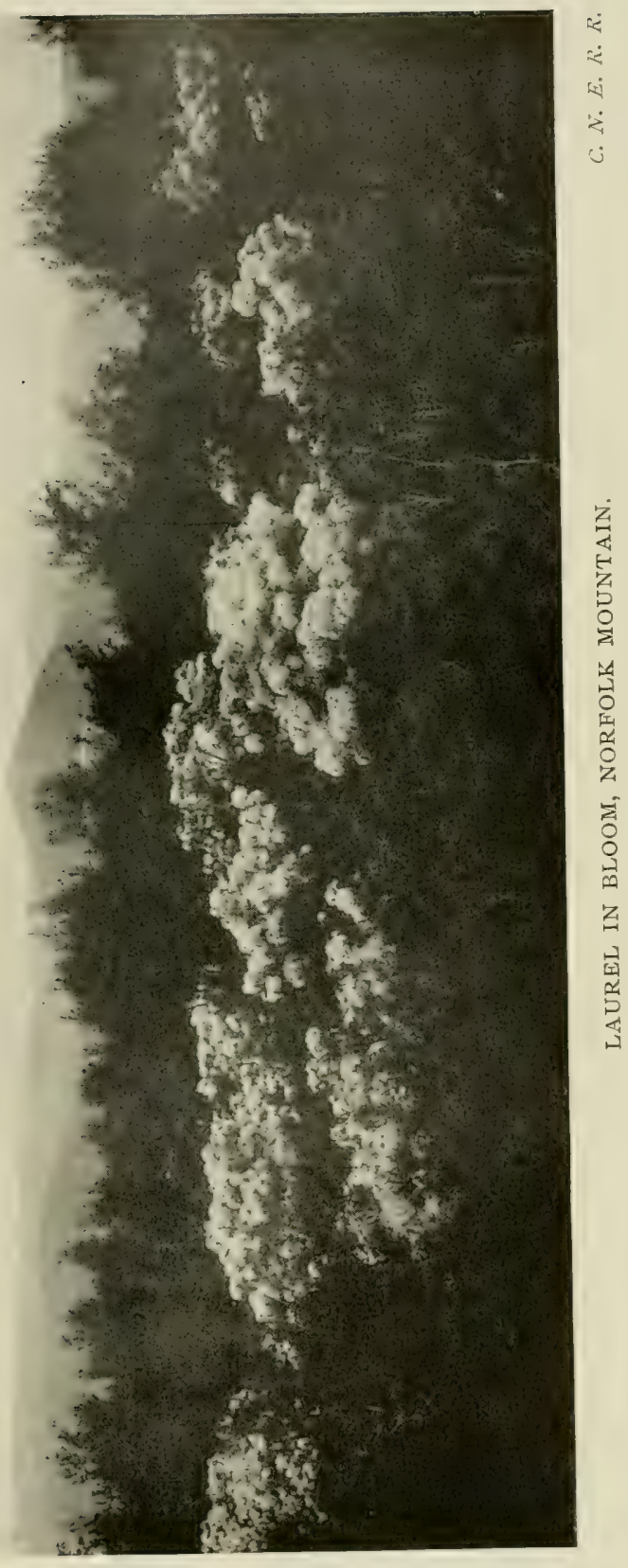


the intelligence of its founder, but the increasing love of flowers through the community.

And we are only in the beginning. The era of universal barrenness and ugliness is past; the new one of universal beauty is not yet here, but it is coming; and no class of men will do more to hasten its advent than those who grow flowers and place them within the reach of everybody.

Rev. Magee P'rati, Hartford.

\section{THE NEW CANAAN NURSERY.}

STEPHEN HOYT'S SONS.

Established in 1848 by Stephen Hoyt of New Canaan and David C. Scofield of Mexico, N. Y. In 1853 Mr. Scofield sold out to his two sons, Lewis and Rufus. In I $856 \mathrm{Mr}$. Hoyt bought out their interests and took in as partners his two sons, Edwin and James. Mr. Stephen Hoyt died in I879. The firm name was then changed to Stephen Hoyt's Sons. At first the business was confined to fruit trees and small fruits; later enlarged to embrace also forest and ornamental trees, shrubs, and plants. The farm now contains five hundred acres - over two hundred in nursery. Stone were abundant and the soil impoverished. The fields have been cleared, drained, and by judicious fertilization and culture the soil is very productive. The stock consists of forty head of neat cattle and eighteen horses; men employed in the busy season one hundred, the rest of the year, fifty. This is the largest nursery in New England and is celebrated for the quality of the stock. The Green Mountain Grape, the earliest good grape, and the October purple plum are some of their introductions. They have an orchard of peaches of twenty acres and are preparing to plant apples on a large scale. Stephen, son of Edwin Hoyt, is also a member of the firm. 


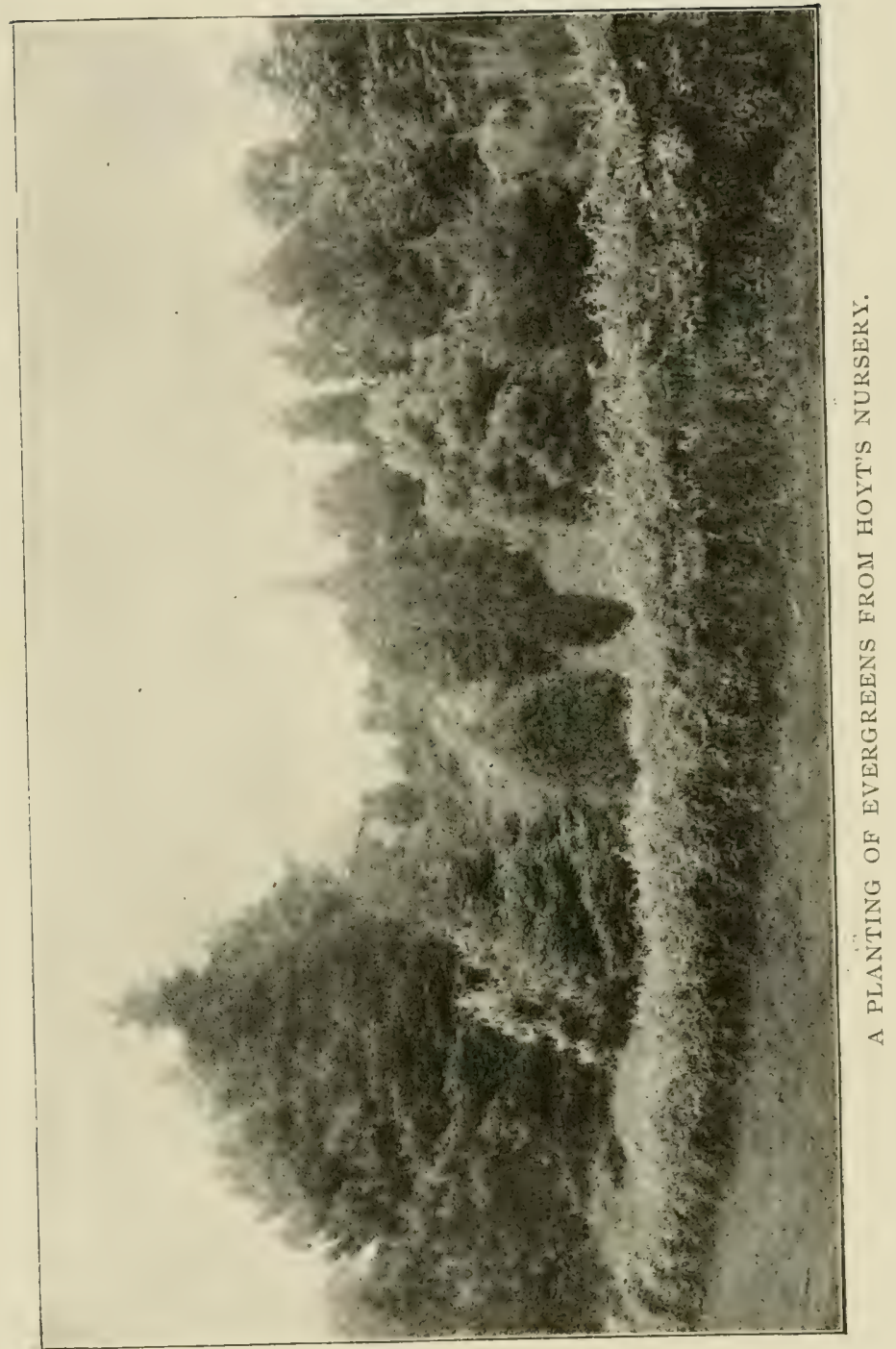




\section{SEED GROWING.}

\section{S. D. WOODRUFF \& SONS, ORANGE, CONN.}

Seed growers and dealers. Also dealers in agricultural implements, fertilizers, etc.

The seed-growing industry of New Haven county, Connecticut, was established about $\mathrm{I} 825$ by Benjamin Hodge of Derby, and Sherman Stone, who lived on the Derby Turnpike in Orange. Mr. Stone had a seed garden of about eight acres, surrounded by a stone wall eight feet high ; part of this wall still remains in perfect condition. Dan Fenn of Milford was prominent in the seed trade fifty years ago. From the example of the above-named pioneers in seed growing there has sprung up a large number of farmers who make the producing of garden seeds of various kinds their chief money crop. Prominent among these is the well-known firm of $\mathrm{S}$. D. Woodruff \& Sons of Orange, Conn. This house was established in I 865 by Mr. S. D. Woodruff, who devoted his energy to producing special select stocks of seed for the wholesale seed dealers throughout the country. In I89I, the business having by this time become enlarged, Mr. Woodruff associated with himself his two sons, Frank C. Woodruff and Watson S. Woodruff, and the firm issued, in I892, a retail seed catalogue. Each year since I 892 an issue in enlarged form has been mailed to thousands of customers in all parts of the country. These catalogues are ready each January, and are sent free to all who write for a copy.

As the demand for all kinds of seeds has very greatly increased for the past few years, Messrs. Woodruff have increased the acreage of their plant until they now have four farms devoted to the culture of seeds. The business gives employment to twenty-five people all the year around. Prominent among the seeds produced by this firm are: carrot, onion, parsnip, beet, turnip, tomato, squash, cucumber, seed potatoes, onion sets, and sweet and field corn seeds. Attention is directed to a photograph, reproduced here, taken 


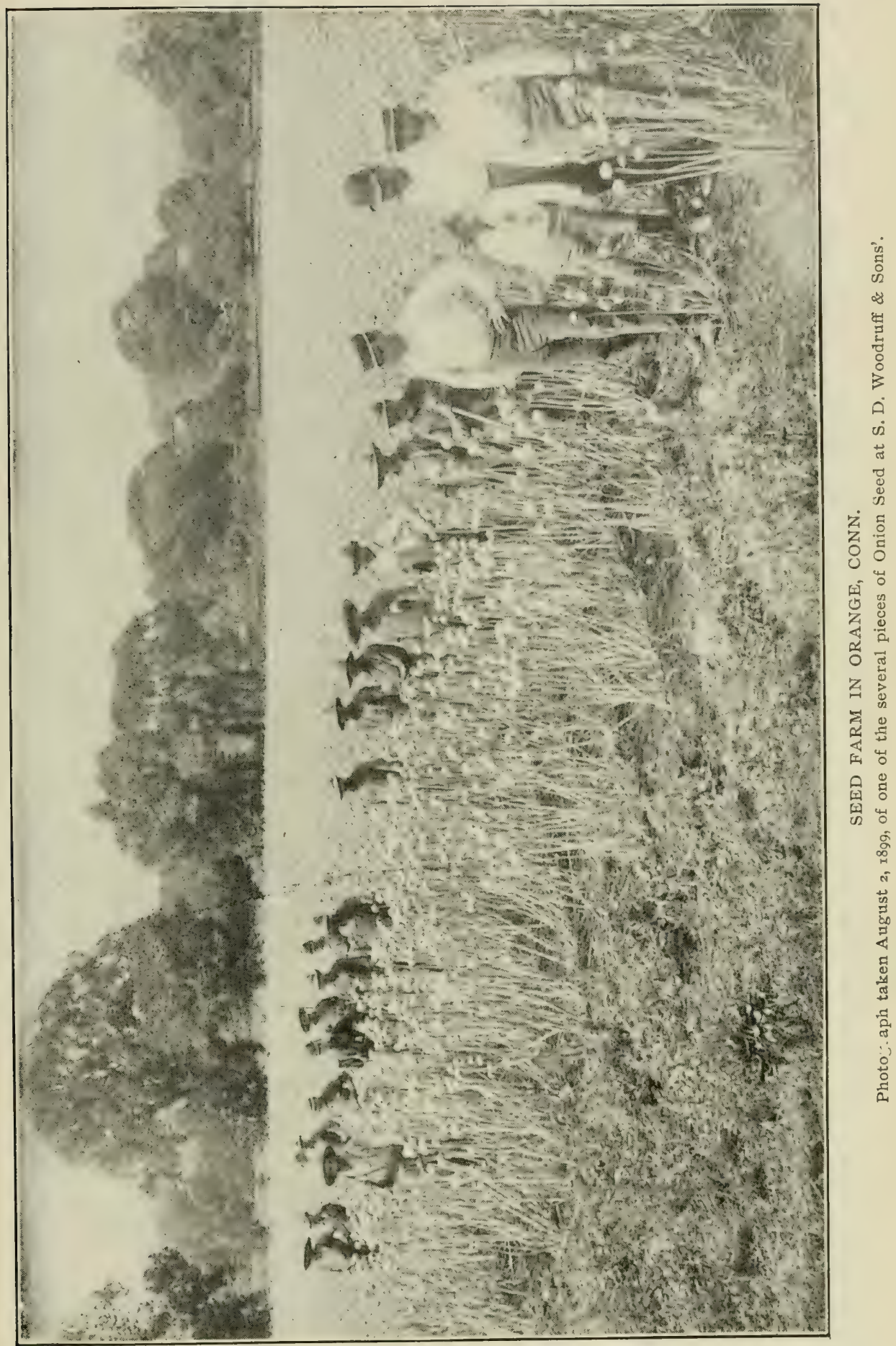


in August, I 899, of a ten-acre field of onion seed on the home farm of this firm.

It is a well-known fact that more garden seeds and sweet corn are produced in the town of Orange and the adjacent towns of Milford and Woodbridge, Comnecticut, than in any other section of the country.

\section{Milford, Conn.}

Seed growing requires not only great skill, but constant care and attention. No seed grower should be satisfied unless he is improving his type of vegretables in quality, embracing color, shape, size, and early maturity. He must constantly watch the development of his plants that he may be able to detect every variation. Climatic conditions are important elements to be considered, and every detail of growth if one wishes to keep his stock up to the standard or make progress. Great care must be used to prevent mixture from prevailing winds carrying the pollen when the plants are in bloom, and thus working ruin upon varieties set in too close proximity. The seed business has kept fully abreast of the times; many new and choice varieties are coming to the front.

EVERETT B. Clark, For The E. B. Clark Co.

\section{MARKET GARDENING。}

We have obtained from Mr. Farnham, the largest small fruit and regetable grower in the State, a list of his principal crops for I900. He combines other branches of agriculture with his market gardening. He improves to the best advantage the opportunities of obtaining fertilizers from the city, and turns to profit the refuse from his market gardening.

\section{A. N. FARNHAM, NEW HAVEN, CONN.}

Grower of fruits, plants, and vegetables, Crescent Gardens, Westville. Breeder of high class swine, land and water fowl. New milch cows constantly on hand.

We raised in, I900: I,296 bushels Lima beans, 276 bushels dandelions, 3,575 dozen bunches beets + bushels, 414 bushels string beans, 160,528 ears sweet corn, 4,206 dozens cucumbers, 8,367 citron melons, 6,536 watermelons, 
4,000 lettuce, 2, IS7 bunches onions, 3,000 bushels onions, 400 bushels peppers, 4.879 bushels potatoes, I, 500 dozen radish, 2, I00 dozen squash, 680 bushels spinach, 49,292 quarts strawberries; 7,792 baskets tomatoes, 3,890 quarts raspberries, 8,79 I quarts blackberries, I,09 I bbls. kale, I0,388 lbs. grapes, I0,079 quarts currants.

The raising of onions and other vegetables for New York is conducted successfully in all the shore towns of Fairfield county. Seed is bred with very great care by these marketmen, and their home-grown seed has often a pedigree of half a century on the same farm or neighborhood, and they would not use as a gift seed grown elsewhere.

In proximity to all our cities small fruits and vegetables are raised for market in connection, generally, with milk supply, but all over the State the home garden and orchard furnish to the professional man, as well as to the farmer and artisan, luxuries and substantials of living, and in most families these labors instead of toil are recreation to all the household and make a threefold return for the time bestowed, in food, in health, and in change of employment, which is better than idleness, for rest. These family-kept gardens rival, in their products of fruits and flowers, those of the florists and professional gardeners, and of the suburban grounds where special gardeners are employed; and though Connecticut is not all a garden, it is full of gardens, for soil and climate are kindly, and the nooks and corners of this little State furnish shelter and adaptation, and lend a charm to these artificial adornments.

Wethersfield and vicinity for a century has been prominent in onion culture. Of late years, growing seed of onions and other vegetables has taken the place as a market product, and the reputation of Wethersfield seeds is not confined to Connecticut.

\section{THE TOBACCO CROP IN CONNECTICUT.}

Almost from the time of its settlement, tobacco has been raised in Connecticut. As early as I640 its culture was favored by laws which restricted the use of tobacco to that 
grown within the colony, by a fine of five shillings for every pound expended on the foreign-grown article. In r662 a duty of two pence per pound was laid on all tobacco brought into Connecticut.

Nearly a century later inspectors were appointed to see that only sound, merchantable leaf was exported from the colony.

It is stated that at no time prior to 1800 did the annual production of the State exceed twenty thousand pounds.

By I 840 it was a regular farm crop in the Connecticut Valley. It was not till I 845 that it was introduced into the Housatonic Valley.

At first "shoestring" tobacco, a narrow-leaved variety, was raised. This was a heavy-bodied leaf and unsuited for wrappers. In I $833 \mathrm{Mr}$. B. P. Barber of East Windsor is said to have introduced from Maryland the broad-leaved variety, which was specially suited for cigar wrappers, and which is now chiefly raised in New England.

At present two sorts are raised,_- "Connecticut Broadleaf," seen in its perfection east of the Connecticut River near Hartford, and "Connecticut Havana," which is raised much more commonly than the other, both in the Connecticut and Housatonic Valleys. Both varieties are thin, elastic, silky, having little flavor, and commanding higher prices than any other wrapper-leaf raised in the United States, excepting a comparatively small amount of Sumatra leaf raised in Gadsden Co., Florida.

At present more than eight thousand acres are planted to tobacco in this State, yielding over two million pounds of cured tobacco leaf. The prices vary very greatly, and there is no other crop in which quality makes such radical differences in market price. The very highest prices paid for any crops raised in 1900 were perhaps twenty-eight to thirty cents per pound in the bundle. Fifteen to eighteen cents per pound was about the average price.

The only lands well suited to the crop are light, sandy 
soils and sandy loams. Clay in the soil, whatever the system of fertilization or tillage, makes the leaf too dark and heavy for the present trade demands, nor can wrapper-leaf of good quality be grown within twenty miles of salt water.

The available tobacco lands of the Connecticut Valley have been mapped by the Division of Soils of the U. S. Department of Agriculture, and we understand that a similar map of the Housatonic Valley is contemplated.

Tobacco soils require very liberal fertilization, the cost for fertilizers alone ranging from fifty to eighty dollars an acre. Cotton-seed meal, castor pomace, tobacco stems, bone, cotton hull ashes, wood ashes, and sulphates of potash, with horse manure, are the materials most used. Muriates and large applications of quickly decomposing animal matters seriously damage the burning quality and flavor of the leaf.

The quality of leaf has been gradually improved during the last twenty years to meet the more exacting demands of the tobacco trade. In I 892 an association of tobacco growers was formed - The Connecticut Tobacco Experiment Co. - which, in co-operation with the Connecticut Agricultural Experiment Station in New Haven, has been engaged ever since in experiments on the fertilization, curing, and fermentation of the wrapper-leaf.

The results of this work are annually published in the Reports of the Agricultural Station and have commanded widespread attention.

At present, experiments are in progress, in a considerable number of places, on the growth, in Connecticut, of Sumatra wrapper-leaf, under artificial screen and shade. The work of the Tobacco Co. and the Agricultural Station in I900, c0-operating with the Division of Soils of the U.S. Department of Agriculture, demonstrated that exceptionally fine leaf of this variety could be grown in the State. The tests now in progress will tend to show whether, at present prices, this can be done at a profit.

E. H. Jenkins, PH.D. 
SHEEP INDUSTRY.

In location and soil this State is peculiarly adapted to sheep raising. The uplands are rolling or hilly, and the valleys well drained, so that almost the entire State, except where land is too valuable for other uses, is suitable for sheep grazing.

While it may be said that no pasture is too good for a sheep, it is equally true that sheep will thrive on rough hillside or weedy pastures not well adapted for dairy or beef cattle.

Not only is this State an ideal place for growing and keeping sheep, but nowhere else can the flockmaster get so quick and so adequate returns for his marketable products. The great woolen industries are in the Eastern States, and the wholesale wool dealers of Hartford pay the highest prices for wool, while the freight from any point in Connecticut is so small a percentage of the price as hardly to be appreciable.

While the climate and pasturage are suitable for all breeds of sheep, the markets make a medium or coarse wool sheep most profitable. While the fleeces may not be quite so heavy, the wool brings a good price and the lambs and mutton find near by, in all parts of the State, the best of markets.

It may be possible to put Western spring lamb into Connecticut markets as good as even the mutton from a South Down sheep fattened on Connecticut hills, but an experience of many years would not warrant me in saying that it ever was done.

As our butter and eggs bring a better price than Western products, because of our nearness to markets, and the fitness of our soil and surroundings enable us to produce these articles and get them to the consumer in the best possible condition, so our lamb and mutton should and would, if properly marketed, bring not only more than the Western farmer gets, but more than the Western meat retails for in Eastern markets.

With such advantages it may be considered remarkable that Connecticut has not more flockmasters. The manufact- 
uring villages that furnish us the best markets in the world unfortunately furnish many dogs that enjoy an occasional day's or night's outing, and within five miles of such a place sheep must have some protection. On some farms sheep may be pastured so near the farmhouse that at the sight of a dog they will run for the yard.

As the State pays a bounty of $\$$ Io for the killing of a dog found worrying sheep, this plan adds rather than subtracts from the profits of sheep keeping. There are thousands of acres of land in Connecticut admirably adapted for sheep pasture that can be bought at a low price. Such land usually needs fencing, and at the present time a wire-netting fence is more economical than a rail fence. Such a fence should be high enough to keep in sheep and keep out dogs. No careful observer doubts but that the time is near at hand when thousands of acres of Connecticut land now lying idle will again be pastured, and in the reclaiming of these pastures there is no animal to be compared to the sheep.

R. S. HinMian.

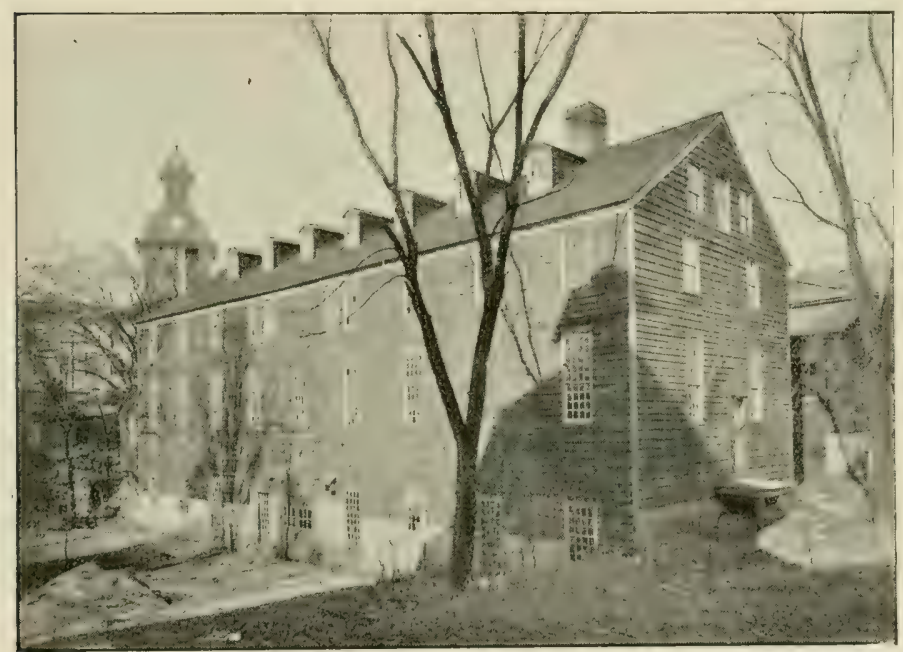

OLD WOOLEN MILL

Conn. Monthly. Of Gen. David Humphreys; built 1806 , Seymour, formerly Humphreysville. 
The early settlers brought the common sheep of England with them. Britain had then many distinct breeds, but unimproved, producing coarse or medium wool well adapted to home manufacture, hardy and prolific. Black sheep or a dark brown were quite common and were favorites, as the wool needed no coloring.

But a great change took place in $\mathbf{I} 802$ when Gen. David

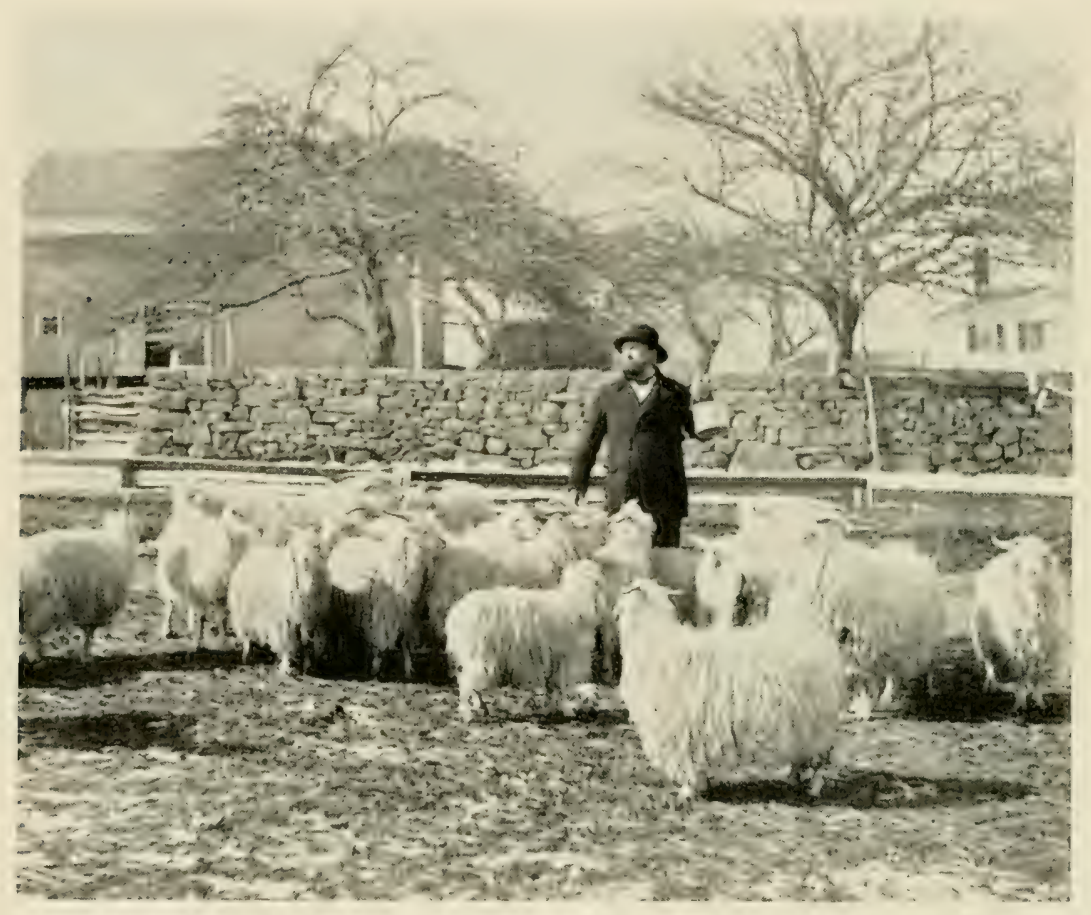

ANGORA GOATS.

Owned by the late Hon. James A. Bill, Lyme.

Humphreys of Derby imported two hundred Merino sheep from Spain. The laws of Spain did not allow the export of these sheep, but Gen. Humphreys, our minister to Spain, was permitted to bring with him a flock of these sheep that wrought a greater revolution in agriculture in America and the world than any other incident in. history.

Consul William Jarvis from Vermont in I 809 obtained 
200 more, followed by larger importations by the thousands, by himself and others. Bred pure and improved by the Atwoods and others of Litchfield county, and by the Vermonters, they have had a world-wide reputation, and in twenty-five years, by cross breeding, had obliterated our old stock of socalled natives. Later, importation of French Merinos by the late John A. Taintor of Hartford, and of the various breeds of English sheep, have given us some of the best stock of the world, and it is difficult to account for the lack of interest, the depression in this department of agriculture, the neglect of an animal so important in developing the natural resources of the State, but a revival will surely come, for as Mr. Chamberlain says in his letter elsewhere, "this is not prophecy but a necessity." Gen. Humphreys was a native of Derby ; graduated at Yale, I77I ; showed much literary talent; served his country as a patriot and a soldier. "He also did much for the promotion of agriculture; and just previous to his death, in I 8 I 8 , was making exertions to form a society for the purpose of procuring a farm for agricultural experiments."

\section{LARGE HAY CROPS, GROWN BY GEORGE M. CLARK, OF HIGGANUM, CONN.}

These cuts show a portion of an acre, which in I 887 produced 12,245 pounds of dry hay first crop. This acre has produced more than six tons of dry hay, first crop, each year

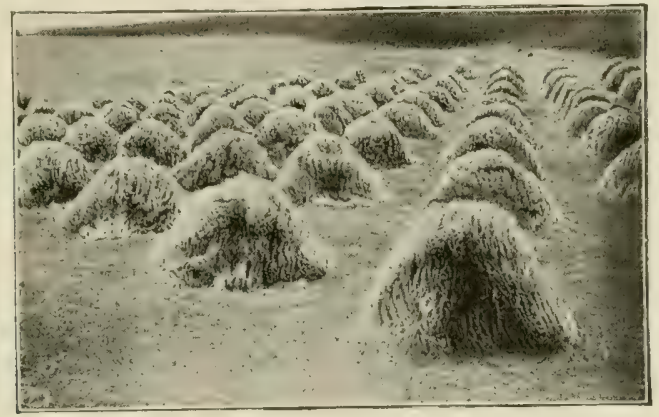

HAY FIELD.

Geo. M. Clark, Higganum. 
since that time. Seven-eighths of an acre adjoining has yielded 87 tons of dry hay at one seeding, two crops each year, in eleven years. This land, in I 886 , was considered one of the worst worn sections in New England, and in fifteen months, by intense cultivation, care and less than, a quarter of an ounce to the square foot per year of bone, muriate of potash, and nitrate of soda, it has yielded, as above stated,

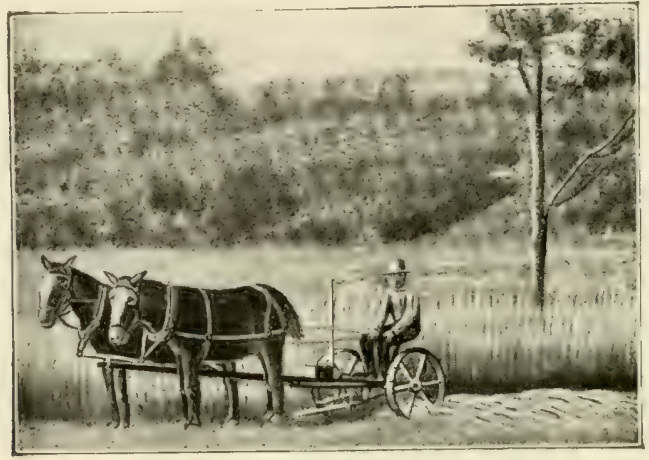

HAY CROP

Of Geo. M. Clark, Higganum. Over six tons of hay raised on an acre.

more than six tons each year. There is much talk about the worn farms of New England, but if the land is intensely cultivated and properly cared for, it is one of the most productive sections on this continent. I speak from a personal knowledge of the soil conditions.

I have found it easy to make $\$ 50.00$ per year, net cash profit, on an acre, growing grass. A great many others are making double and triple that amount on an acre by giving it more care. All that is required to make money on these worn farms, is correct cultivation, and proper care, seeding, etc.

George M. Clark.

Mr. Clark has kindly furnished this brief statement of his success in grass growing. The capacity of Connecticut soil in grass production, this foundation crop in all successful agriculture, has never been more thoroughly tested than in 
this case. The tools of the Higganum Company have here had a trial of what they can do when rightly handled. Grass culture alone could justly fill this little book.

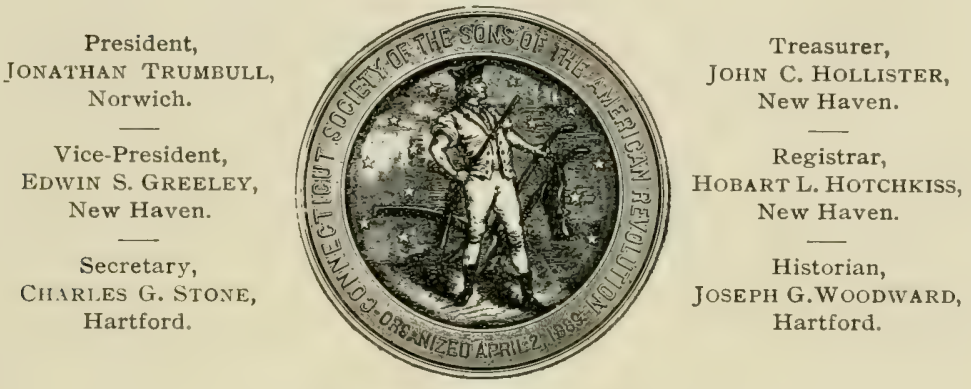

THE LEBANON WAR OFFICE.

The Lebanon War Office was given to the Connecticut Society of Sons of the American Revolution by its owner, Mrs. Bethiah H. Wattles, in I89I. The building was repaired and restored by that Society, and dedicated June I $_{5}$, I90I. It was the headquarters of the Council of Safety dur-

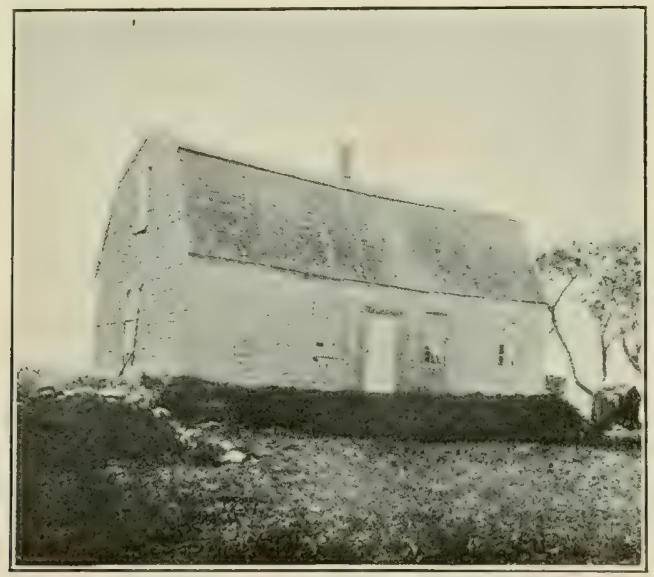

Sons Am. Fev.

WAR OFFICE GOV. JONATHAN TRUMBULL, LEBANON. 


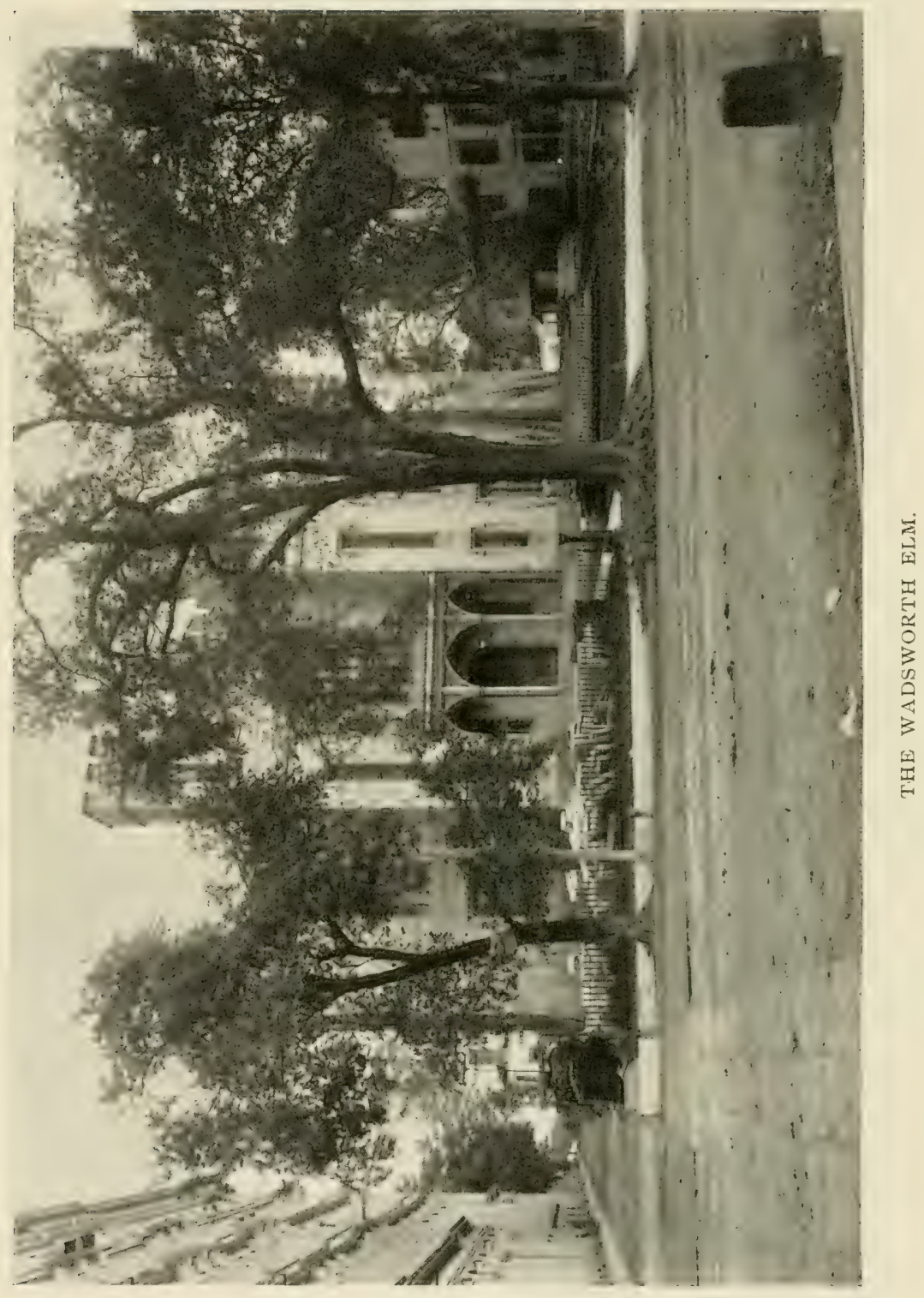


ing the entire period of the Revolution, and I, I45 meetings of the Council were held in the building.

For further particulars regarding this historic landmark and its important history, reference may be had to a book published by the Connecticut Society, Sons of the American Revolution, entitled "The Lebanon War Office."

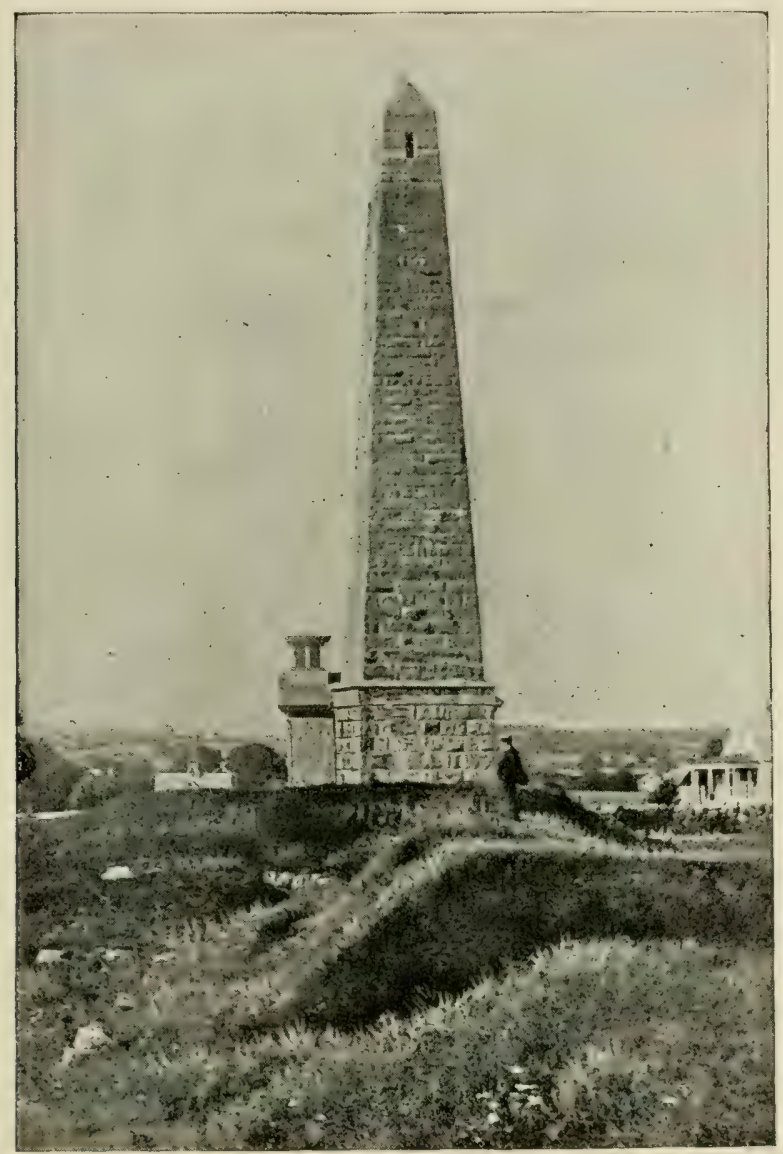

GROTON MONUMENT.

THE WADSWORTH ELM.

The fact is well authenticated that it was at this tree, standing in front of the Wadsworth Athenzum in Hartford, that Washington alighted on his way to Cambridge, June 
29, I775, to take command of the Continental Army. A bronze tablet has been placed upon the tree by the Connecticut Society of Sons of the American Revolution. This tablet was unveiled on the 29th of June, I 893. See year book of the Society for I $895^{-6}$.

\section{PUTNAM PARK.}

This fine park at Redding, Conn., is kept by the State in commemoration of General Israel Putnam. It covers the entire camp of the forces under his command encamped in Redding during the winter of $1777-8$.

\section{THE GROTON MONUMENT.}

As the inscription reads: "This Monument was erected under the patronage of the State of Connecticut, A. D. I830, in memory of the Brave Patriots who fell in the massacre at Fort Griswold near this spot on the 6th of September, I 78 I." The monument stands on Groton Heights, opposite New London, Conn., and is about one hundred and fifty feet high. The story of the historic event it commemorates cannot be told within the present limits. It is fully described in various histories of the American Revolution, and described in detail in "The Battle of Groton Heights," edited by Charles Allyn of New London in 1882 .

\section{THE NATHAN HALE SCHOOLHOUSE AT NEW LONDON.}

This building has recently been purchased by the Connecticut Society of Sons of the American Revolution, with the co-operation of the Daughters of the American Revolution, and is now being restored to its original condition and located on prominent public ground in New London. In this building Nathan Hale taught school for more than a year, leaving his school to join the army, at the time of the Lexington alarm. After this short service he returned to New London, and in July, I775, resigned his position as teacher and enlisted in the Continental Army, in the records of which his name stands as a shining example of self-sacrificing patriotism. Connecticut is proud of this son of her soil, and his 
memory is honored by the preservation of another schoolhouse at East Haddam, where he taught before coming to New London. Several statues and other memorials also honor his memory within the State and elsewhere.

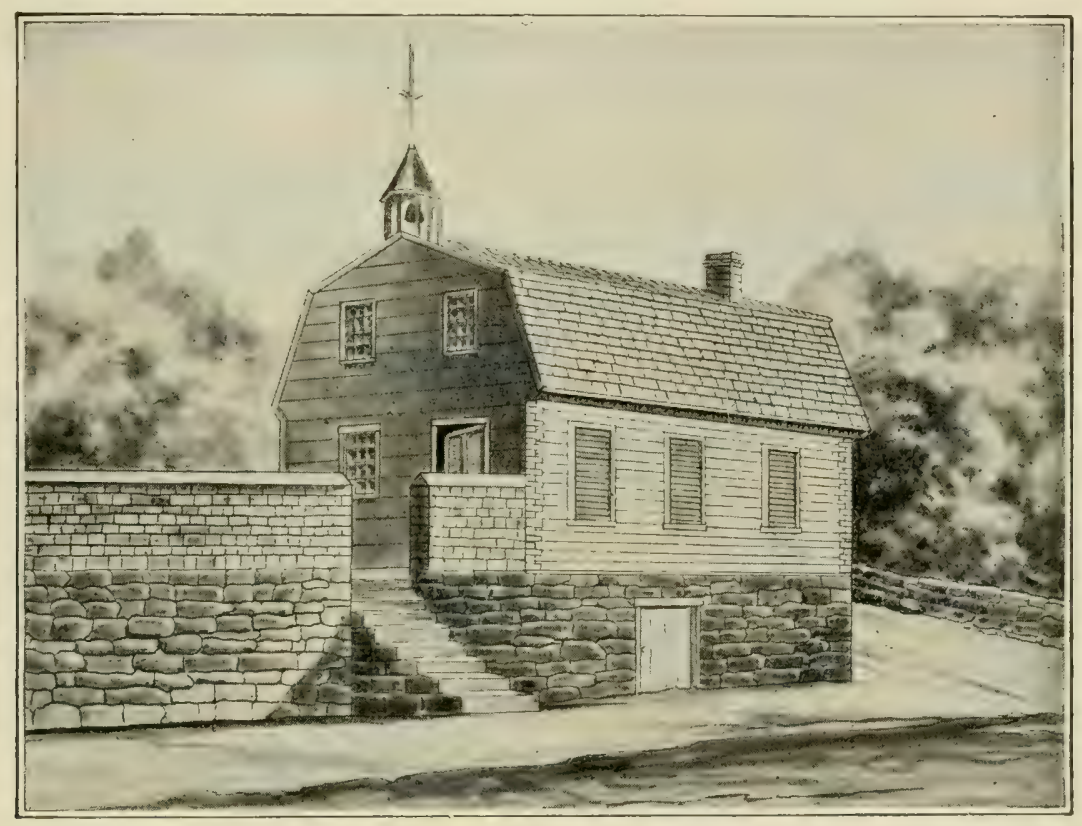

Sons Am. Rev

THE NATHAN HALE SCHOOLHOUSE, NEW LONDON, BEFORE REMOVAL.

CONNECTICUT FORESTRY ASSOCIATION.

E. V. Preston, President, Hartford; Miss Mary Winslow, Secretary and Treasurer, Weatogue.

Forestry in Connecticut demands more than a passing notice. Originally covered with magnificent forests of pine oak, chestnut, and other species in variety, the soil is so natural to the growth of trees that they spring up everywhere if Nature is allowed to have her own way, and hence besides the memorial village and roadside trees that have been planted the landscape is everywhere dotted with trees of every variety often rivaling in beauty the gems of a well-kept park. The elm and the hickory, the maple and the oak, attain their fullest development on our hillsides. The beauty thus added 
to rural scenery now demands attention, and the value of timber as a farm product is admitted as one means of utilizing lands unsuited to cultivation. Yale University and Connecticut Agricultural College have, during the past year, added Forestry to their curriculum, and the U. S. Department of Agriculture has recently given attention to its demands for public consideration.

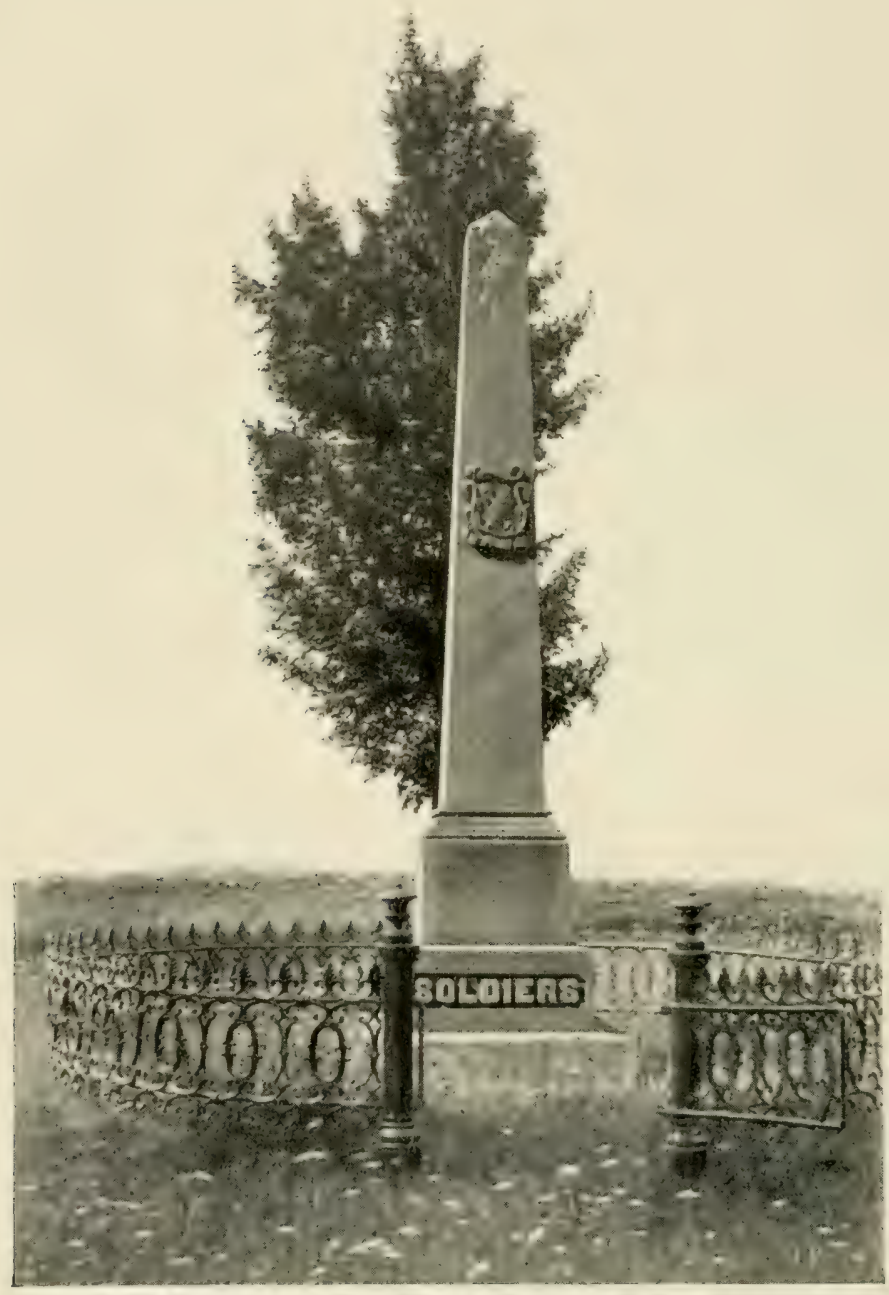

SOLDIERS' MONUMEN'T, KENSINGTON.

Conn. Monthly.

The first monument erected in the country to the Soldiers of the Civil War. 


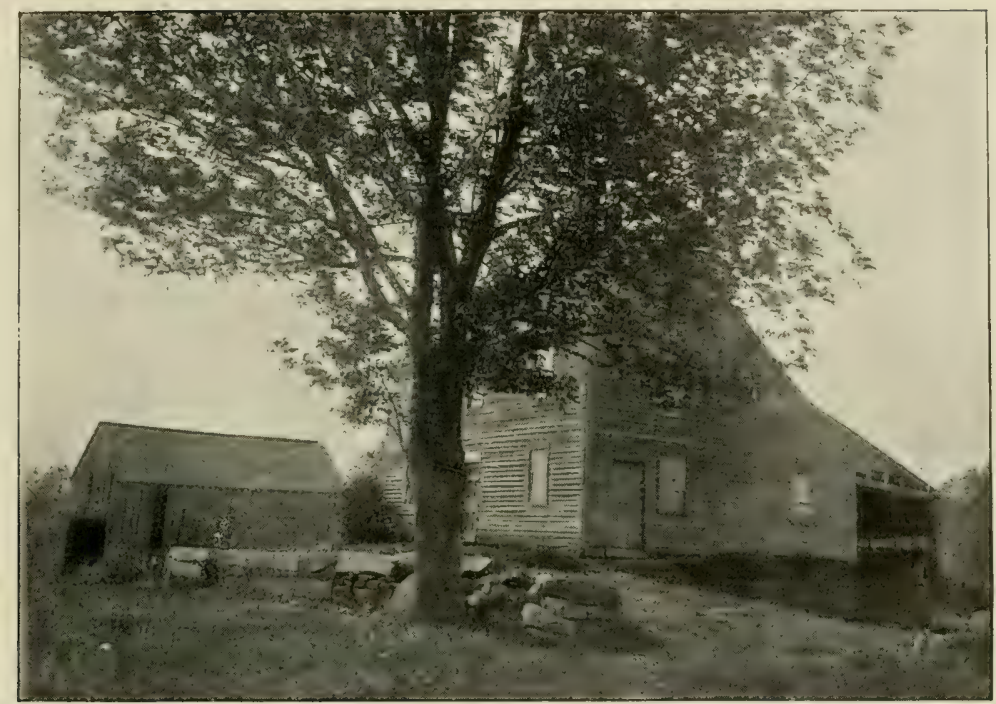

BIRTHPLACE OF JOHN BROWN, TORRINGTON, CONN.

Tor. Print. Co.

The Connecticut Experiment Station is also making practical trials in tree culture, to report expenditure and results. The time was never more propitious than at present for favoring an intelligent management of our forests, and we have high hopes that success will crown our efforts.

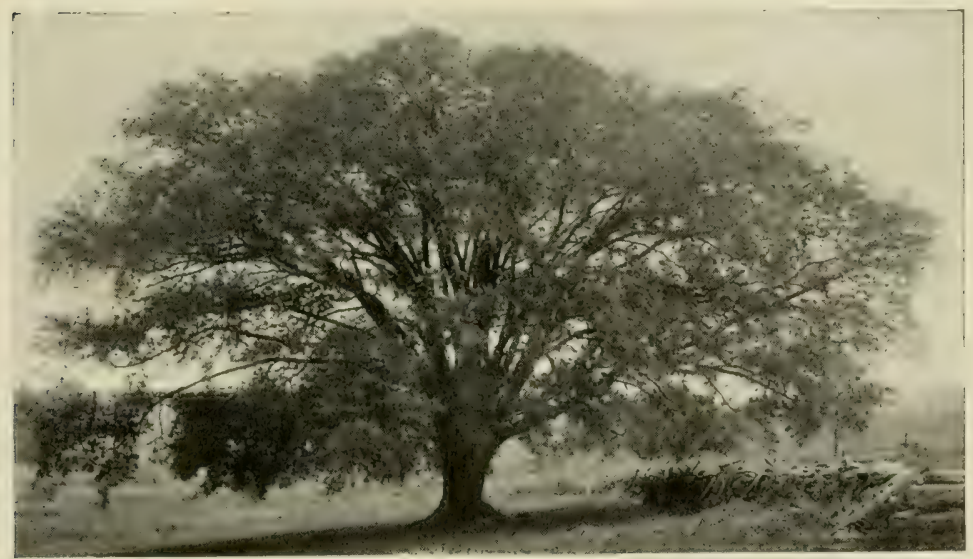

QUEEN MARGARET'S ELM, SHARON. 


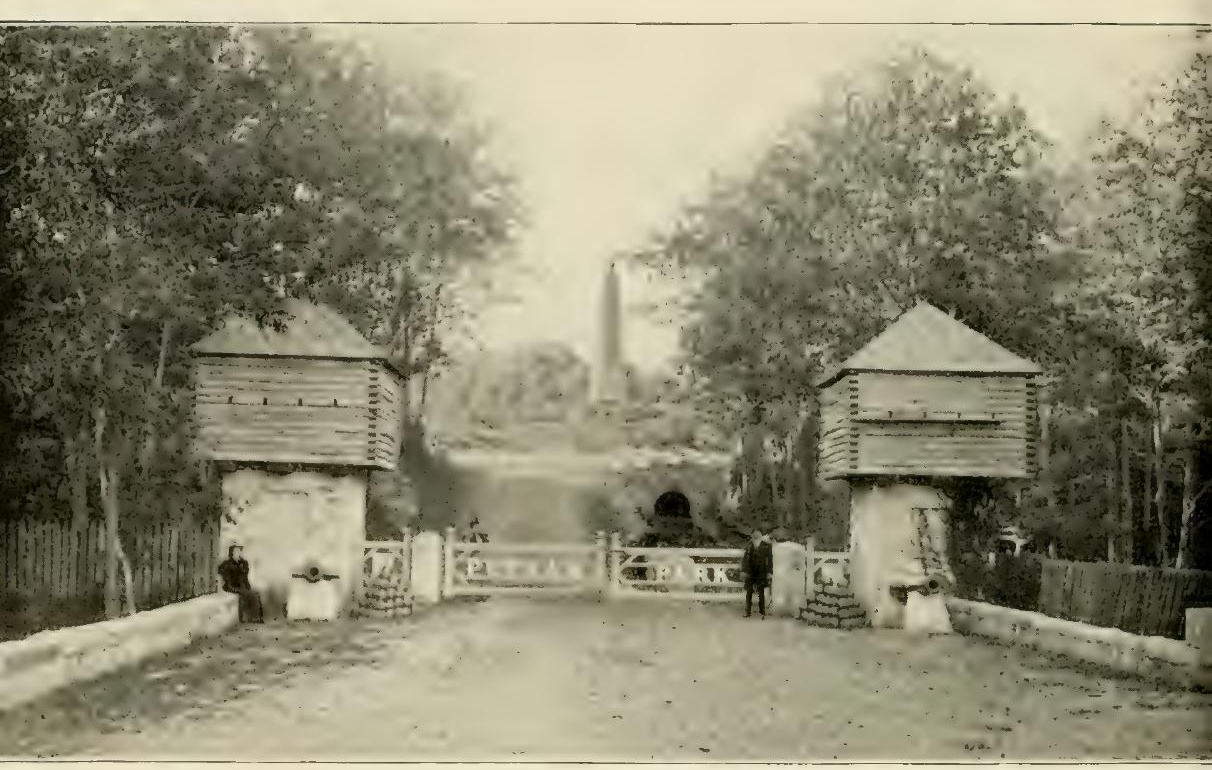

ENTRANCE TO PUTNAM MEMORIAL PARK.

\section{CONNECTICUT PARKS.}

Seaside Park,

$$
\text { bridgeport. }
$$

ACRES.

ACRES.

Beardsley Park,

Pembroke Park,

Washington Park,

Clinton Park,

Lafayette Park,

Wood Park,

$\begin{array}{ll}. & \cdot \\ . & \cdot \\ . & \cdot \\ . & . \\ . & . \\ . & .\end{array}$

127

152

6

4

I

Groton.

Fort Griswold (National Park).

\section{Hadd $a m$ *}

Meeting-house Park,

Field Park,

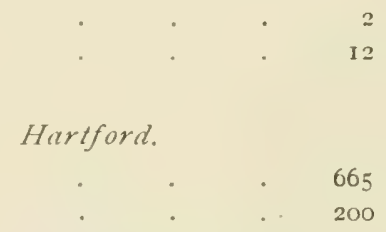

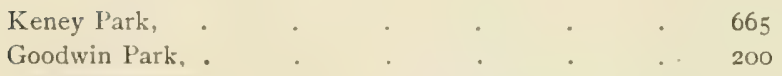

* These parks were given to the people of Haddam, in 1880 , in memory of Dr. David Dudley and Submit Dickinson Field, by their four sons, David Dudley, Stephen, Cyrus, and Henry M. Field. 
Elizabeth Park, .

Pope Park,

Riverside Park,

Bushnell Park,

Capitol Grounds,

Sigourney Square,

Camp Field,

Barnard Park,

Ancient Cemetery.

Tunnel Green,

Village Green,

Franklin Green,

Buckingham Green,

Lafayette Green,

Maple Green,

Washington Green,

Hubbard P'ark, .

City Park,
ACRES.

ACRES.

100
95.1
75
42
15
2.55
3.10
1.71
1.06
.77
.15
.14
.20
.06
.196
.04

$1,21) 4.22$

Heriten.

800

(1)

So6

New britain.

IOO

IOI.O9

New Haven.

East Rock Park,

West Rock Park,

Netu London.

Riverside Park, Memorial Park,

Beach Park, 
Williams Park, Johnson Park, .

Chelsea Parade, Laurel Hill Park. Little Plain,

$$
\text { ACRES. }
$$

$$
\text { I. } 50
$$

.02

13.52

Norzezch.

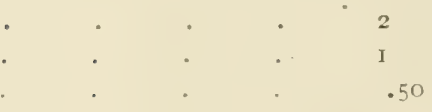

Redding.

Putnam Memorial Park,

Hated bury.

Hamilton Park,

Centre Square, .

\section{Willimantic.}

40 40 43
IO

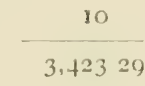

Total for State, .

The Park (unnamed),

List compiled by G. A. Purker, Secretary New England Park Association, Hartford.

In offering this tribute in the interests of Connecticut agriculture, I desire renewedly to express my thanks to all those who have by their contributions of illustrations and reading matter, enabled me to publish in the brief time allowed me even so short a sketch of the conditions in Connecticut affecting agriculture in the past and of promise in the future. Please notice that many of our illustrations are accredited to the Central New England Railway, and to the Connecticut Monthly Magazine.

We regret that lack of space and time does not allow of accepting many other offers in answer to our requests.

T. S. Gold, Secretary. 


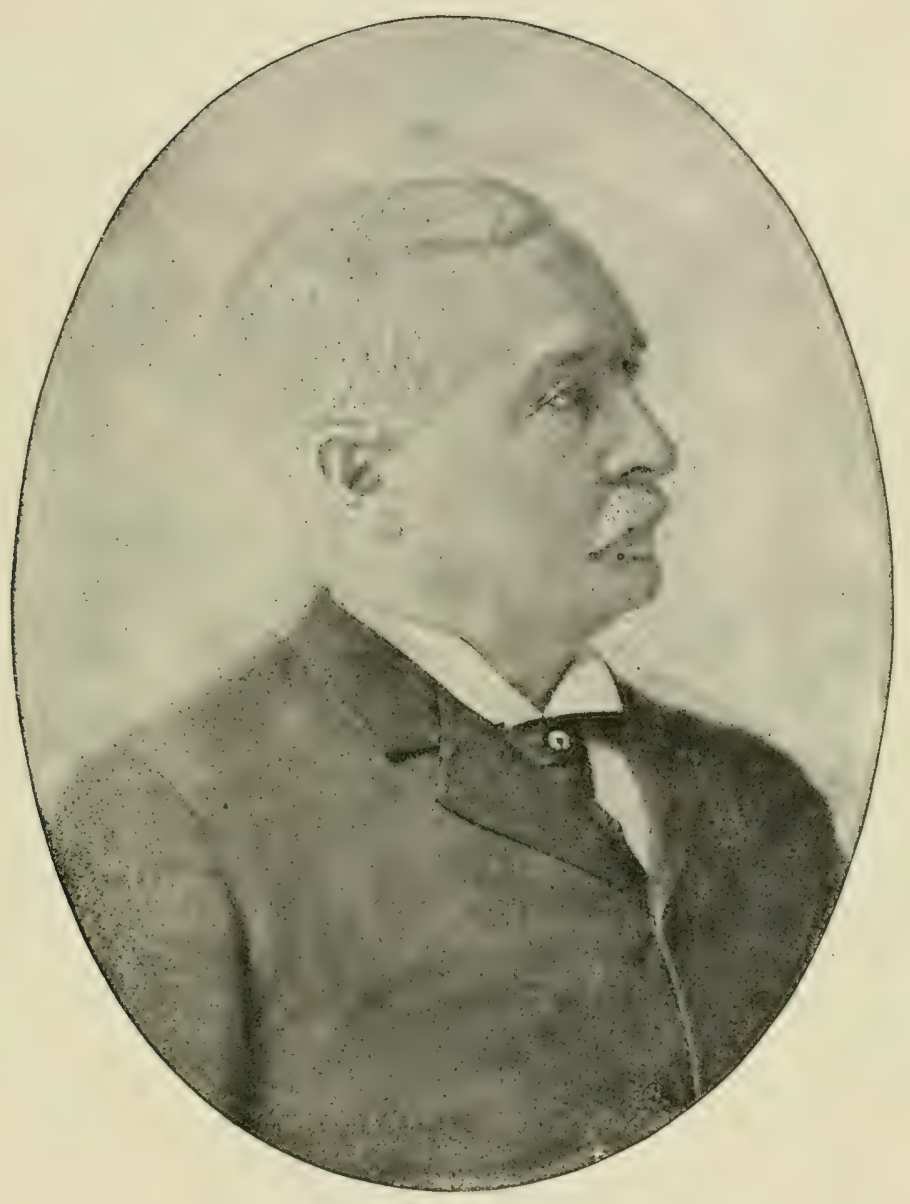

IVALTER HUBBARD, MERIDEN. 


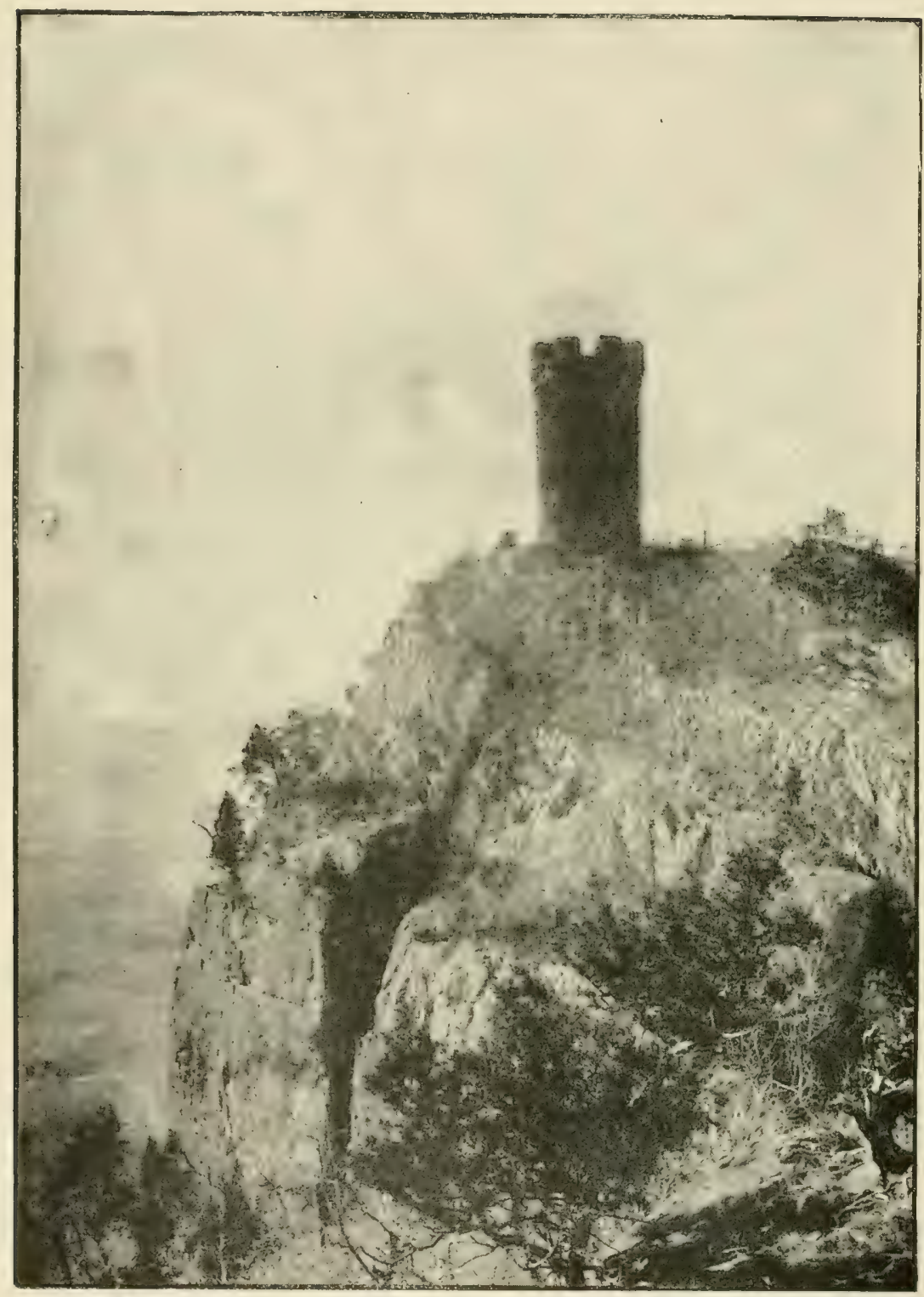

CASTLIE CRAIG TOWER, MERIDEN, LOOKING IVEST. 


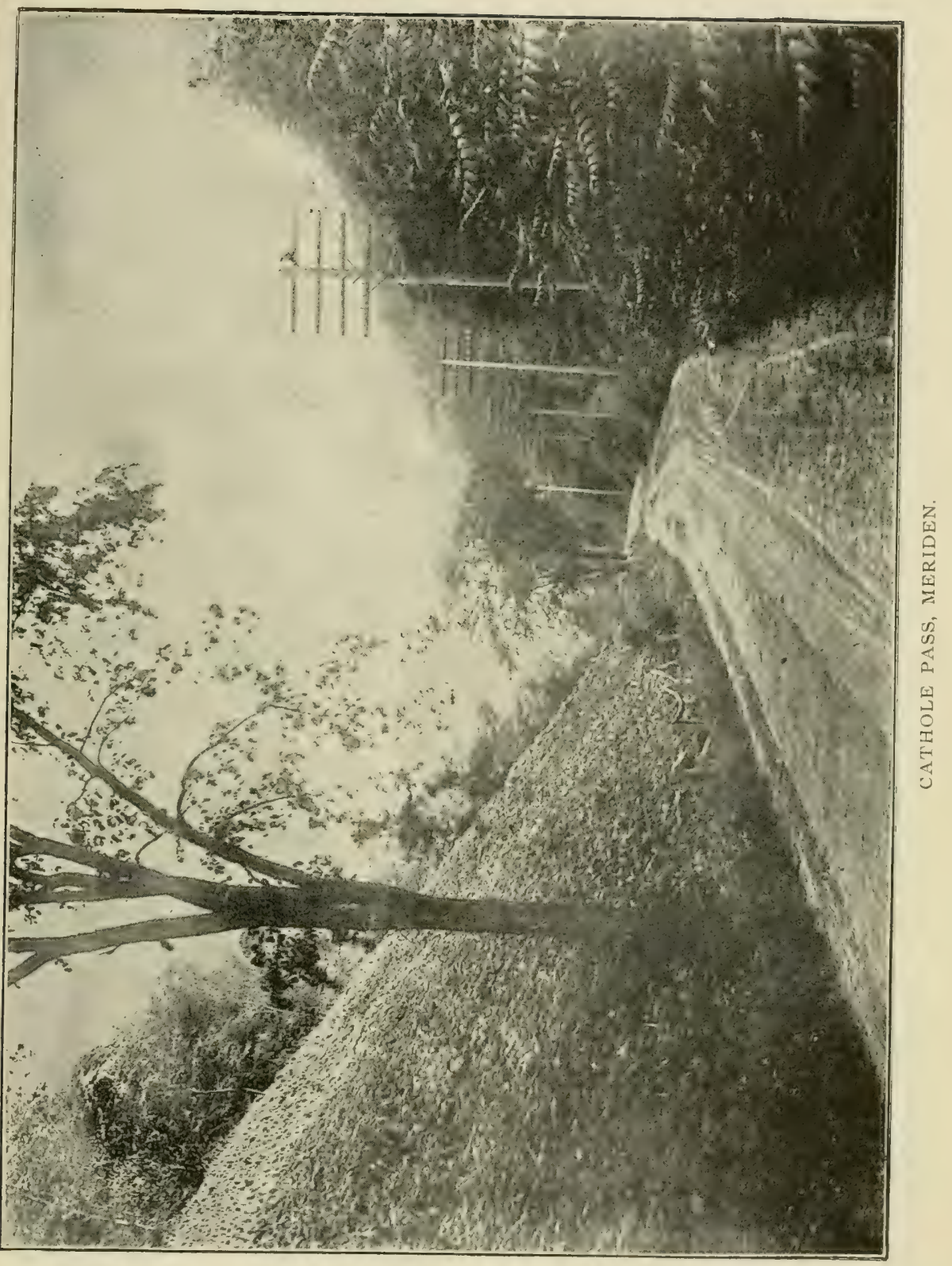




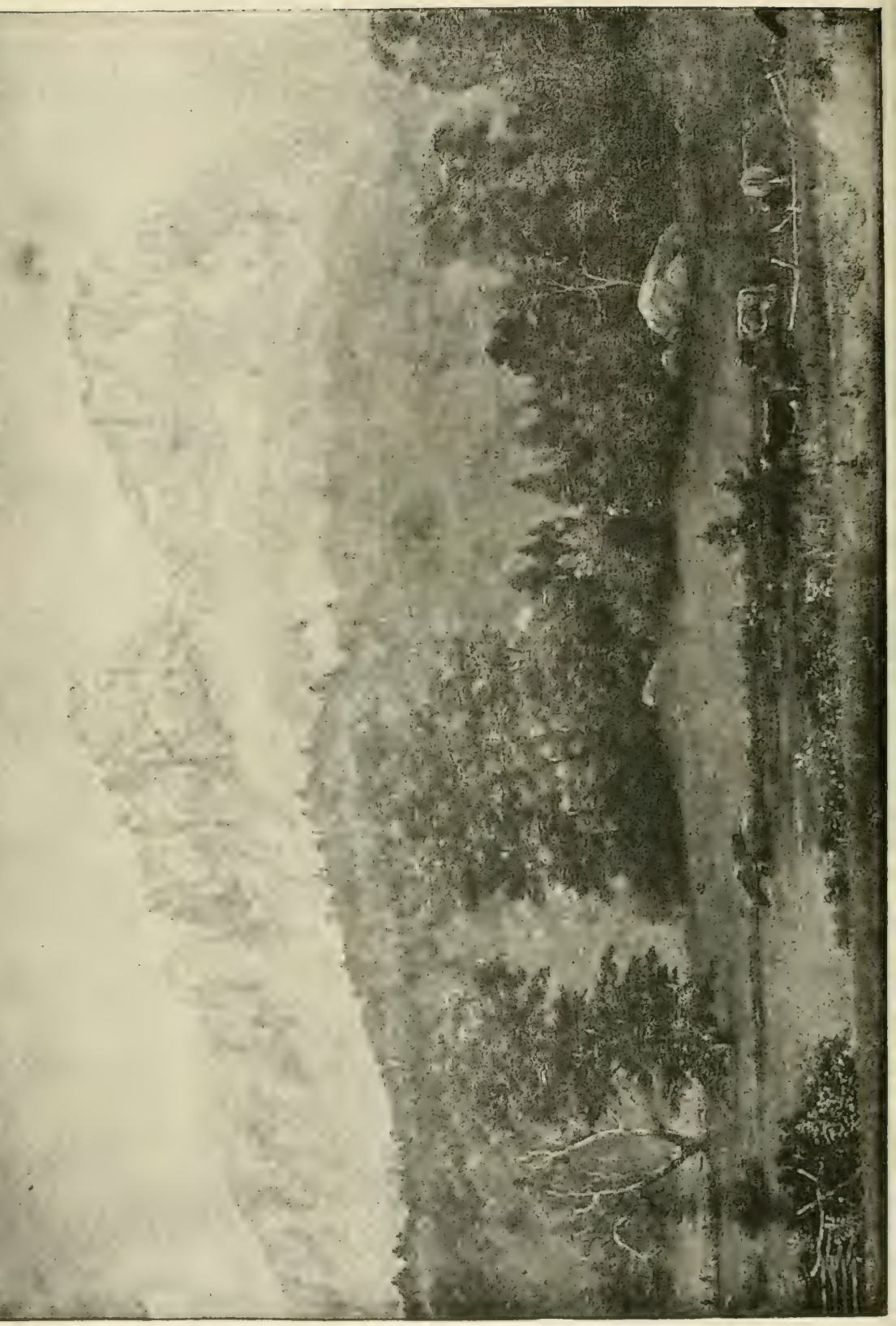







ald

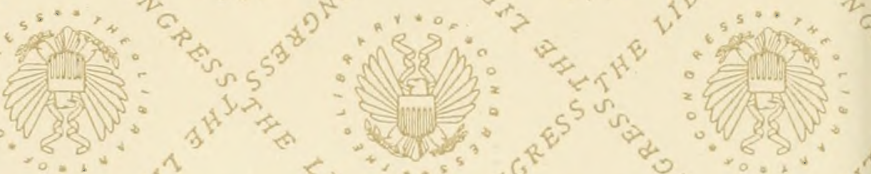

.
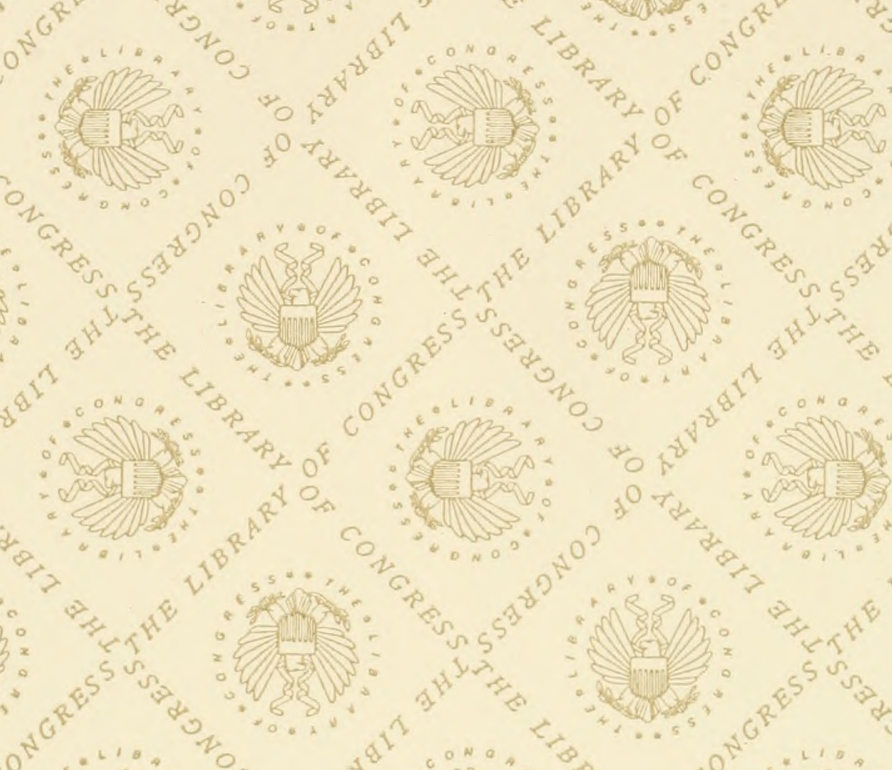

(10.

(a)

妾

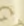

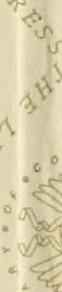



